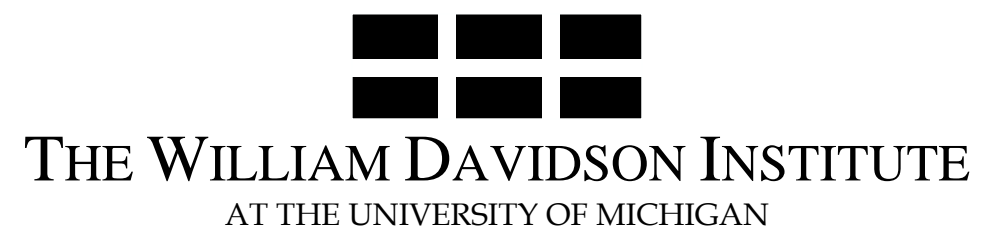

AT THE UNIVERSITY OF MICHIGAN

\title{
Inflation Differentials in the Euro Area and their Determinants - an empirical view
}

By: Juan Ignacio Aldasoro \& Václav Žd'árek

William Davidson Institute Working Paper Number 958

April 2009 


\title{
Inflation differentials in the Euro area and their determinants - an empirical view
}

\author{
Juan Ignacio Aldasoro ${ }^{1} \&$ Václav Žd'árek ${ }^{2}$
}

\begin{abstract}
In this paper, we present evidence on the statistical features of observed dispersion in HICP inflation rates in the Euro area. Our descriptive exercise shows that there is still a remarkable dispersion of HICP inflation rates across the member countries. We find that most of dispersion originates in the non-traded categories of the HICP. This suggests that the main source of dispersion in countries' headline inflation rates is in those components of the HICP where non-traded goods (services, (public) goods with regulated and administered prices) are more intensely represented. We then examine the determinants of inflation differentials in a panel of the states of the Euro area in 1999-2007 using alternative classifications of this group and three different datasets. The evidence presented shows that output gaps and a proxy for price level convergence were statistically significant. On the other hand, some determinants that were found significant in previous studies (for example Honohan and Lane, 2003, 2004; ECB, 2003) has no impact on inflation in our expanded time span (e.g. exchange rate movements)

The dispersion of HICP inflation is expected to increase in the coming years as the new EU member states will join the Euro area. There are some risks for these countries connected with the common monetary policy, which is adjusted more to the conditions of stabilized advanced economies forming the core of the Euro area. This creates potential problems for the EU common monetary policy (ECB), in particular negative (positive) interest rates, their repercussions on investment processes, consumption and the possibility of creating asset bubbles.
\end{abstract}

Keywords: inflation differentials, price convergence, exchange rate, panel data

JEL Classification: C23, E31, F15, F41

\footnotetext{
${ }^{1}$ M\&S Consultores. Address: 25 de mayo 555, p10 (C1002ABK) Buenos Aires. Tel. +49 178 1986577; E-mail: ji.aldasoro@gmail.com.

${ }^{2}$ Centre for Economic Studies, University of Economics and Management in Prague Address: I. P. Pavlova 2, Prague 2, CZ - 120 00. Tel. +42 0224941 056; E-mail: vaclav.zdarek@,vsem.cz.

The authors are post-graduate students at the Institute for the World Economy in Kiel. We are very thankful to Jens Boysen-Hogrefe for helpful comments. We also thank Roman Horváth and the participants of the ASP conference for helpful comments and suggestions. We acknowledge the hospitality provided by the Institute for the World Economy in Kiel. The usual disclaimers apply. Part of the work was written with the support of a grant provided by the Ministry of Education, Youth and Sports (Centre for research of the Czech economy's competitiveness 1M0524).
} 


\section{EXECUTIVE SUMMARY}

Inflation differentials, their origin and evolution are of great relevance for monetary unions. In the particular case of the Euro area, widely acknowledged regional asymmetries within the area represent a major challenge for policy-making since, absent the possibility of adjusting the nominal exchange rate, movements in the real exchange will directly follow the path of inflation differentials.

The first years of existence of the Euro area were associated with diminishing inflation differentials (measured by harmonized index of consumer prices - HICP) and convergence of inflation rates. Since 2004 the observed inflation differentials have remained stable and a non-negligible degree of dispersion across national inflation rates in the Euro area has been at times observed. In the wake of these events, several studies have tried to shed some light on the main drivers and determinants behind this fact. The contributions to this literature range from descriptive analyses backed by panel regression results to small calibrated models trying to mimic the main features of the Euro area.

This paper combines a descriptive exercise analyzing inflation dispersion in the harmonized inflation index (HICP) and finally a multivariate panel regression analysis stressing the relevance of key macroeconomic variables as drivers behind inflation differentials, with different specifications of the Euro area group and alternative inflation measures in the context of three different databases.

The analysis of inflation dispersion covers the period from January 1999 to December 2008 and is also done through different specifications of the Euro Area: the EA12 (the Euro area consisting of 12 member states), the EA11 (EA12 without Luxembourg), the EA10 (EA11 without Greece) and the Euro area with the new EU Member States EA13 (EA12 including Slovenia), and EA15 (EA13 including Cyprus and Malta). Additionally, two decomposition of the overall HICP index are used; the first uses the five main subindices: Services (overall index excluding goods), Industrial Goods excluding Energy, Energy, Processed Food and Unprocessed Food; and the second one, detailed structure of the HICP (the twelve subindices) based on the COICOP classification. Additionally, a structural decomposition of HICP indices is performed. Finally, the descriptive analysis concludes with a comparison with US regional inflation data.

Inflation differentials in the Euro area seem to be a characteristic pattern of the monetary union and they tend to be significant and long-lasting. As the main drivers of dispersion can be marked the Services sector (a proxy for non-tradable sector), which contributed to the dispersion of inflation in an important way. Conversely, some sectors that can be referred to as tradable (industrial goods apart from energy) seem to have relatively low power in determining and explaining dispersion of prices. The more detailed analysis based on twelve subindices revealed that highly volatile indices are those that do have relative low weight in the HICP index (such as Communications) and/or cover prices of goods and services that are regulated (administered for example Health or Education) and an adjustment of those prices, if it is linked to other tendencies may result in significant dispersion of inflation. We found in this detailed analysis that among the main drivers were the Food and beverages and the Housing, Furnishing and goods and services appertained to these subindices.

A brief comparison between the Euro area and U.S. regions only confirmed that while inflation 
differentials in the U.S. are short-term and a sign of adjustment, the differentials of inflation in the Euro area had a structural pattern and are connected with different reactions of individual Euro area economies to common shocks.

For the panel regressions we used two annual and one quarterly databases and three to five different specifications for the Euro area. The general model includes as independent variables proxies for the output gap, price level convergence, fiscal position and nominal effective exchange rate. It additionally presents time dummies that capture Euro area aggregates, so the regressions should therefore explain inflation differentials across Euro area countries as idiosyncratic national movements.

We rely on GMM estimation since there is potential endogeneity of some variables to inflation rate in our model, namely output gap and fiscal balance. The overall results point to the relevance of cyclical factors and to a lesser extent real convergence factors (output gaps and price level convergence respectively). Coefficients for the output gap were somewhat smaller than in previous studies (lying between 0.005 and 0.013). For price level convergence the coefficients lie between -0.02 and -0.05 . For example, a coefficient of -0.05 implies that a country with a price level $20 \%$ below the Euro area average is likely to experience inflation 1\% above the area average. Almost no support is found for the nominal effective exchange rate, a result that can be explained by the extension of the time span used for the analysis and allows us to state that after almost ten years of common currency, exchange rate movements have a diminished impact on inflation differentials, which in turn implies that the policy concern of minimizing the impact of real exchange rate overshooting becomes a second order concern.

The present analysis can be extended to include additional variables that may play a role in explaining differentials like for example productivity levels (accounting for the so-called Balassa-Samuelson effect) or oil prices. The other possibility seems to be a structural model for the Euro area. More importantly, it could be complemented with an up-to-date stylized New Keynesian model an up-to-date stylized New Keynesian model. 


\section{Introduction}

Inflation differentials, their origin and evolution are of great relevance for monetary unions. In the particular case of the Euro area, widely acknowledged regional asymmetries within the area represent a major challenge for policy-making since, absent the possibility of adjusting the nominal exchange rate, movements in the real exchange will directly follow the path of inflation differentials.

The Euro area was created in 1999 and consisted of eleven member states. In 2001 Greece joined and then there were three subsequent rounds of extension - from the group of new EU Member states (Slovenia in 2007, Cyprus and Malta in 2008 and finally, Slovakia in 2009) adding up to 16 member states with more than 325 million people in January 2009. Inflation differentials in Europe have been increasingly discussed on different occasions. In particular during a few years before and after the beginning of the Euro area and introduction of the euro (1997-1998 and 1999-2000) and after data availability made analyses possible (from mid 00's onwards). The opponents (see for example Feldstein, 1997; Obstfeld, 1997, 1998) have pointed out that the Euro area is not a currency union as laid by Mundell's article (Mundell, 1961). The main criticism is based on the seminal work of Friedman (1953) highlighting the necessity to have floating exchange rates as an adjustment tool for changes in real exchange rates in case of asymmetric adverse shocks. Other issues are connected with impacts of economic integration in the Euro area, the European Central Bank and its single monetary policy. For example adequacy of the ECB's inflation target for the Euro area including catching-up countries experiencing relatively high inflation due to the Balassa-Samuelson effect, see Sinn and Reutter (2001). ${ }^{3}$

It is a well-known fact that inflation differentials in a monetary union are supposed to be a sign of imperfect (incomplete) integration of particular regions (countries) which are part of that union. It may be argued that it is due to unfulfilled conditions postulated by authors whose articles have contributed to a strand of the literature of the Optimal Currency Areas ${ }^{4}$. As a result, there might be a narrower room for manoeuvre for the European Central Bank (ECB). On the other hand, the process of integration of New Member states and other European countries (EU-15) and in particular the removing of trade barriers might have an impact on the on-going process of equalization of national prices (because of increased competition, reduced risk, etc.).

The first years of existence of the Euro area were associated with diminishing inflation differentials (measured by harmonized index of consumer prices - HICP) and convergence of inflation rates. Since 2004 the observed inflation differentials have remained stable and a non-negligible degree of dispersion across national inflation rates in the Euro area has been at times observed. In the wake of these events, several studies have tried to shed some light on the main drivers and determinants behind this fact. The contributions to this literature range from descriptive analyses backed by panel regression results to small calibrated models trying to mimic the main features of the Euro area.

In this paper, we present evidence on the statistical features of observed dispersion in HICP inflation rates in the Euro area. Our descriptive exercise shows that there is still a remarkable dispersion of HICP inflation rates across the member countries. In a simple decomposition based on 12 subindices corresponding to the COICOP we find that most of dispersion originates in the

\footnotetext{
${ }^{3}$ An insider view on the whole process of establishing monetary union in the 90's is presented in a newly published book of a founding member of the Executive Board of the ECB, see Issing (2008).

${ }^{4}$ For an overview see for example De Grauwe (2007).
} 
non-traded categories of the HICP. This suggests that the main source of dispersion in countries' headline inflation rates is in those components of the HICP where non-traded goods (services, (government) goods with regulated and administered prices) are more intensely represented. We complement the analysis by examining the determinants of inflation differentials in a multivariate panel of the states of the Euro area for the period 1999-2007, using alternative classifications of this group (included set of countries) and different datasets and time frequencies to assess the robustness of the findings and avoid misguiding conclusions due to the presence of outliers. The evidence presented shows that output gaps and a proxy for price level convergence were statistically significant. On the other hand, some determinants that were found significant in previous studies (for example Honohan and Lane 2003, 2004; ECB, 2003) did not have impact on inflation in our expanded time span (e.g. exchange rate movements), it may be due to relative short time span in previous studies.

The paper is organized as follows: in Section 2 we shortly sketch the theoretical reasons why inflation differentials could be a cause for concern and we review the literature on inflation differentials in the Euro area. Section 3 presents a descriptive analysis of inflation differentials and basic measures of inflation divergence in the Euro area for 1999-2008, complemented by a brief comparison with the experience of the United States. Section 4 describes the model and dataset used for the panel estimations, the results of which are presented in Section 5. Finally, Section 6 summarizes our findings and offers suggestion for future studies.

\section{Inflation differentials in the Euro area}

In this section, we first shortly state the theoretical reasons that call for special attention to inflation differentials in a monetary union in general and the Euro area in particular. We then go through a more detailed review of the empirical literature that deals with the problem of inflation differentials in the Euro area.

\subsection{Inflation differentials in a monetary union: why worry?}

As it is generally accepted that the ECB can only credibly target area-wide inflation for the Euro area as a monetary union (see ECB, 2003) and that inflation differentials are not a rare phenomenon to other monetary unions (being inflation differentials among US regions the recurrent example), it is worth asking why one should worry about the presence of inflation differentials in the Euro area. Moreover, some drivers of inflation in a monetary union are often seen as benign, namely price level convergence and differences in basket composition among its members (see for example Honohan and Lane, 2003). Nonetheless, it has to be acknowledged that not all sources of inflation differentials are benign as the aforementioned.

Countries in a monetary union face the same short-term interest rate set by the monetary authority. In this context, persistent inflation differentials will give rise to persistent short-term real interest rate differentials, which in turn may generate self-reinforcing internal imbalances. As pointed out by Busetti et al. (2006) among others, these divergences may be exacerbated by cyclical considerations, since countries that are growing above trend are likely to have stronger inflationary pressures and therefore experience lower (even negative) real interest rates that could further add to the inflationary momentum.

A moderating effect to this self-reinforcing overheating process is emphasized by Angeloni and Ehrmann (2007): absent the possibility of resorting to nominal exchange rate adjustments, differentials in inflation rates will be reflected in different paths for real exchange rates. Those countries that exhibit an above (below) average inflation will show an appreciating (depreciating) 
real exchange rate, a process that will be gradually reflected in a loss (gain) of competitiveness that would eventually compensate the effects of negative (positive) real interest rates. Nevertheless, the extent to which these two effects compensate each other is an empirical matter, and problems related for example to hysteresis in the international market share of a country with temporary loss of competitiveness or persistence mechanisms after a shock with supply rigidities should not be ignored. Furthermore, the asset price bubbles (or overheating of domestic stock or asset markets, for some details see for example Honohan and Lane, 2003) that can be generated due to negative real interest rates may not be compensated at all by movements in the real exchange rate.

An additional effect may come through the exchange rate channel: if countries from the monetary union have different composition of extra-union trade, movements in the exchange rate can play a significant role as a mechanism for importing inflation from non-member countries and thus generate inflation differentials within the union.

A special cause for concern about inflation differentials in the Euro area with respect to other monetary unions like the United States is the absence of inter-regional smoothing mechanisms (Mundell's adjustment mechanisms) present in the latter; migration and labour mobility in particular in Europe are relatively weaker (see Perotti, 2004) ${ }^{5}$ - this aspect is regularly examined and assessed in reports of the EU Commission ${ }^{6}-$ and there is no unique strong federal fiscal system (which in turn implies that inter-regional smoothing mechanisms are relatively weak in the Euro area) as a counterpart of the common monetary policy conducted by the ECB. ${ }^{7}$ Domestic fiscal policies, which are constrained by the Stability and Growth Pact, sometimes fuel inflation divergence between countries due to the fact that fiscal policy has been pro cyclical and not counter-cyclical since the beginning of the 90's and in particular since 1999 (see EC, 2006 or IMF, 2004) as it may be if the idea of automatic fiscal stabilizers during an economic cycle is relevant $^{8}$. Therefore, it is difficult to expect fiscal policy to be systematically conducted so as to smooth neither output nor price differentials. Additionally, specific institutional features from the Euro area may give rise to political economy considerations: inflation is generally disliked especially in the absence of the possibility to adjust the exchange rate. To the extent that inflation

\footnotetext{
${ }^{5}$ A brief comparison of the U.S. and European labour markets can be found in EC (2006a). In spite of the well-known problems with comparisons of U.S. states and EU countries, about $3 \%$ of the working age population in the US moved from one state to another (yearly average between 2000-2004), in the EU-15, it was only $0.1 \%$ of the working age population for individual countries, and about $1 \%$ for NUTS1 regions. This fact was also studied for the European community in the $80^{\prime} \mathrm{s}$ by De Grauwe and Vanhaverbeke (2001). This study found regions with higher and lower willingness to migrate - for example in richer countries. A comparison with the situation before the monetary union was created can be found for example in Decressin and Fatás (1995) or Bentivogli and Pagano (1999). An overview and a survey of literature related to this issues see HMS (2003). For an extensive discussion of adjustment mechanisms in a monetary union see De Grauwe (2007).

${ }^{6}$ The latest edition of this report EC (2008) assesses first impacts of the EU enlargement in 2004 and 2007 on the labour market. The new EU member states have brought about significant flows of workers, in particular affecting labour markets of Ireland, Italy and the UK. However, labour mobility within the euro area countries has remained at rather low levels.

${ }_{8}^{7}$ For theoretical discussion and related problems see for example Beetsma et al. (2001).

${ }^{8}$ For discussion and review of literature see for example HMS (2003); IMF (2008) or Dullien and Schwarzer (2009). Study Fatas and Mihov (2009) shows that the US fiscal policy has been countercyclical and fiscal stabilizers have worked as they should work (in particular over the years 1999-2007), fiscal policies in the Euro area have not changed substantially (i.e. procyclicality - despite restrictions imposed by the Stability and Growth Pact rules) but have become less volatile and the automatic stabilizers are more important. Auerbach (2008) reviews the situation in the USA over last few decades. The keystone of the fiscal systems that while budgets of the U.S. states are controlled by fiscal rules that are relatively tight (comparable with a sort of annual balanced budget requirement), there have been different budget control regimes at the federal levels and there is any at such law at the national level.
} 
differentials don't prove to be self-correcting, public opinion and politicians may blame the common currency for their misfortunes.

\subsection{Related literature}

The literature on inflation differentials in the Euro area has followed two main avenues ${ }^{9}$ : on the one hand small New Keynesian models, and on the other, descriptive analysis backed by regression results, typically panel estimations.

The first group relies on microeconomic foundations to build stylized models which are in turn calibrated to study theoretical responses to shocks. One of attempts going in this direction is study Angeloni and Ehrmann (2007), who analysed inflation and output differentials through a stylized 12-country model of the Euro area, each represented by aggregate supply (hybrid Phillips curve) and demand (output gap) equations. Using quarterly data from 1998:I to 2003:II, they find evidence of demand or potential output shocks as the main driving force behind inflation differentials, followed in order of importance by cost-push and exchange rate shocks. They also find support for inflation persistence as a propagation mechanism of inflation differentials. Additionally, their analysis suggests that the targeting of area-wide inflation by the monetary authority is likely to lead to low cross-country differentials. ${ }^{10}$

In the same direction, Hofmann and Remsperger (2005) build a model for the Euro area countries (excluding Luxembourg) based on a hybrid Phillips and IS curve, and estimate it through panel instrumental variables over the period 1999:I up to 2004:I. They conclude that inflation differentials were mainly driven by differences in cyclical positions and fluctuations in the effective exchange rate, combined with a high level of inflation persistence. Price level convergence, proxied by the 1999 PPP price level relative to the Euro area and by the average implied Balassa-Samuelson ${ }^{11}$ effect, fails to prove statistically significant. Their results also indicate the presence of endogeneity with respect to the persistence of inflation differentials, since inflation persistence is significantly lower (virtually zero) in the group of countries that already experienced low and stable inflation rates in the past, while it is higher for the rest of the countries.

Finally, in this first group we can consider Altissimo et al. (2005), who study the statistical features of inflation in the Euro area and then analyze the long-run determinants of inflation differentials in a monetary union using a two-country dynamic factor model with fully flexible prices. The descriptive analysis shows there is still a sizable dispersion of HICP inflation rates in the Euro area, originated mainly in the Service category of the harmonized index (where non-traded goods weight more). Dynamic factor model is used to decompose the aggregate and sectoral measures of inflation dispersion into common (for all countries driven by common determinants) and idiosyncratic (i.e. country specific) components. Altissimo et al. (2005) find that asymmetric productivity shocks in the non-traded sector account for a significant fraction of the variability in the relative price indices across their stylized dynamic factor model of a monetary union consisting of two heterogeneous regions. Additionally, and in contrast to the conventional

\footnotetext{
${ }^{9}$ There is also an alternative approach, not widely used, which studies the time series properties of inflation differentials through unit root tests. The main examples of this approach are Busetti et al. (2006), who conclude that inflation rates show diverging behaviour after 1998 and identifies two clusters of high and low inflation, and Gregoriou et al. (2007) who find support for the hypothesis of stationarity when they account for endogenously determined structural breaks and non-linear mean reverting behaviour of inflation differentials.

${ }^{10}$ In contrast to this, Benigno (2004) concludes that optimal "inflation targeting" should put more weight in stabilizing inflation in those countries that exhibit more price stickiness.

${ }^{11}$ See Balassa (1964) and Samuelson (1964).
} 
explanation of movements in the real exchange rate as a consequence of movements in relative productivity in the traded sectors, they find that symmetric sectoral productivity shocks in one country may generate sizable inflation differentials.

As mentioned above, the second group in the literature focuses on the combination of descriptive and regression analysis and has its main starting point in Honohan and Lane (2003), whose approach we largely follow here (see Section 4 below). These authors analyze inflation differentials in the Euro area over the period 1999-2001 through a multivariate panel data model estimated by Ordinary Least Squares (OLS) and Generalized Method of Moments (GMM). They propose a fairly general specification for inflation differentials including measures of cyclical position (output gap), fiscal position (primary surplus), price level convergence (lagged price level) and external position (lagged differenced nominal effective exchange rate). Their evidence points to a highly significant price level convergence effect, external position and output gap across almost all specifications. On the other hand the evidence on fiscal position is inconclusive, being insignificant and significant, but contrary in sign to prior expectations, in the OLS and GMM regressions, respectively. In the wake of these results, the output gap is thought to capture most of the effect that can come through the fiscal channel.

A special emphasis is given by Honohan and Lane (2003) to the external position effect captured by the nominal effective exchange rate, suggesting this variable plays an important role in explaining inflation differentials since Euro area countries have quite different trading patterns and hence show variability in exposure to currency fluctuations. This argument is further stressed in Honohan and Lane (2004), where the authors update the panel regressions in Honohan and Lane (2003) to cover the 1999-2003 period. Although the new evidence points to a less significant effect of the nominal effective exchange rate once the output gap is included in the regression specification, the overall interpretation of results is essentially unchanged. A novel exercise in Honohan and Lane (2004) is the distinction between exchange rate appreciation and depreciation. They are found to have asymmetric effects, where the latter variable has a stronger impact on inflation differentials than the former. This in turn helps explaining why the effect for the period 1999-2003 is slightly weaker than for 1999-2001, since the former includes a period of euro appreciation.

Horváth and Korpnická (2008) analyze inflation differentials in Euro area New Member (NM) states in 1997-2007, following the approach of Honohan and Lane (2003) whose results are used for comparison. Their main findings suggest that, vis-à-vis the Euro area, exchange rate appreciation and higher price level in NM states are associated with narrower inflation differentials, while fiscal deficit and positive output gap seem to lead to higher inflation differentials. The effect of price level seems to be more important in NM states than in the Euro area. Overall, the results indicate that real convergence factors rather than cyclical variation are likely to be more significant for inflation developments in NM states as compared to the Euro area.

A very comprehensive article in this second group is Égert (2007), where the analysis is extended for the EU-27 in 1996-2005. The author starts with a detailed review of the factors that can influence inflation differentials, namely structural and cyclical factors influencing services, house and good prices, and price level convergence. This is followed by a statistical approach consisting of an accounting framework and panel estimations through GMM. Like in the rest of the literature, no support for the Balassa-Samuelson effect is found. For the Euro area, the two most robust variables are inflation persistence and cyclical fluctuations. Second in order of importance are oil prices and regulated prices although oil prices are quantitatively negligible, particularly for the transition economies. The remaining variables studied (house prices, exchange rate influencing through import openness (pass-through), VAT and fiscal stance) are found to be less stable and 
dependent to a great extent on the measure of output gap, the time period and the estimation method used $^{12}$. When the Euro area is pooled together with transition economies, initially different comparative price levels and progress in real convergence captured by changes in the composition of HICP and the growth rate of per capita GDP tend to lead to significantly higher inflation rates.

Finally, an important additional contribution to the literature on inflation differentials that does not fit our main classification but is anyway worth mentioning is ECB (2003). This extensive study shows that inflation dispersion in the Euro area is not notably different from that observed in the United States, while inflation differentials are more persistent in the former. This is particularly relevant since the adjustment between regions of a monetary union is likely to be harder the less flexible the goods and factor markets of these regions are, a feature present in Europe in comparison to the United States. An inflation accounting exercise suggests that the diversity in inflation rates since 1999 is mirrored by a considerable diversity in profit margin changes and unit labour costs. Also, most countries with a relatively high degree of openness tend to have their inflation differentials accounted for to a larger extent by the evolution of import costs. Supporting evidence is found for the cyclical position measured by the output gap as a factor behind inflation differentials. Further evidence is found for the exchange rate as a significant variable, although its influence on inflation dispersion is regarded as temporary. Finally, some support is found for price level and income convergence as drivers of inflation differentials, especially for countries like Greece, Portugal, Ireland and Spain.

\section{Inflation in the Euro Area}

This section will focus first on a description of inflation differentials and basic measures of inflation divergence in the Euro area using various specifications of HICP subindices. Then we proceed to a comparison of inflation in the Euro area and the US regions (four main regions and then using data for eight regions?).

\subsection{Some stylized facts on inflation development in the Euro area}

We analyze inflation dispersion and its determinants in the Euro area (EA) with different composition of this group of countries: the EA12 (the Euro area consisting of 12 member states), the EA11 (EA12 without Luxembourg), the EA10 (EA11 without Greece) and the Euro area with the new EU Member States EA13 (EA12 including Slovenia), and briefly the EA15 group (EA13 including Cyprus and Malta).

In this paper, we use the Harmonized Index of Consumption Prices (henceforth HICP), which consists of harmonized indices of consumer prices for a standardized basket of goods and services consumed by a country, where weights are based on household expenditures. Our data covers the Euro area as a whole (and chosen aggregates excluding some countries such as the new EU member states for comparability of our results with previous studies) and individual countries for the period from January 1999 to December 2008. Apart from the overall HICP, we also used two decomposition of the overall HICP index. The first used the five main subindices: Services (overall index excluding goods), Industrial Goods excluding Energy, Energy, Processed Food and Unprocessed Food; and the second one detailed structure of the HICP (the twelve subindices) ${ }^{13}$

\footnotetext{
${ }^{12}$ The result obtained for the exchange rate stands in contrast with the findings of Honohan and Lane (2003), fact that Égert (2007) interprets as evidence of the sensitivity of the estimates to the extension of the period used by a couple of years. For transition economies the effect of the exchange rate is more relevant though weakening over time.

13 The time-series HICP Education until December 1999 is not available for Belgium.
} 
based on the COICOP classification. ${ }^{14}$

The change of domestic price level (annual percentage change of inflation $-\pi_{t}$ ) is computed for individual countries $(j)$ from monthly indexes of HICP using the following formula (see e.g. Altissimo et al., 2005; Gregoriou et al., 2007).

$$
\pi_{j, t}=\left(\ln I_{j, t}-\ln I_{j, t-12}\right) \cdot 100,
$$

where $I_{i, t}$ is the HICP for month $t$ and country $j$.

We start with some basic descriptive statistics which are based on unweighted and in the following step on weighted indices for the Euro area countries. Since the Euro area emerged, dispersion of average inflation rates has somewhat declined and then remained stable. Table 1 presents some unweighted measures of the HICP inflation rates for the Euro area countries over the analysed period (1999-2008). In addition, Figure 1 shows inflation differentials, their changes and the main divergence indicators in the Euro area (EA12) for the same period (i.e. from January 1999 to December 2008).

Table 1: Descriptive statistics for the Euro area, 1999-2008

\begin{tabular}{|l|c|c|c|}
\hline & mean & SD & CV \\
\hline Austria & 1.83 & 0.72 & 0.39 \\
Belgium & 2.20 & 0.64 & 0.29 \\
Finland & 1.96 & 0.76 & 0.39 \\
France & 1.85 & 0.59 & 0.32 \\
Germany & 1.60 & 0.74 & 0.46 \\
Greece & 3.09 & 0.62 & 0.20 \\
Ireland & 3.11 & 1.18 & 0.38 \\
Italy & 2.41 & 0.33 & 0.13 \\
Luxembourg & 2.37 & 1.26 & 0.53 \\
Netherlands & 2.42 & 1.27 & 0.53 \\
Portugal & 2.54 & 1.10 & 0.43 \\
Spain & 3.02 & 0.97 & 0.32 \\
\hline EA12 & 2.40 & 0.45 & 0.19 \\
\hline Slovenia & 5.11 & 2.32 & 0.45 \\
\hline EA13 & 2.61 & 0.55 & 0.21 \\
\hline Cyprus & 2.53 & 0.88 & 0.35 \\
Malta & 3.35 & 0.99 & 0.30 \\
\hline EA15 & 2.58 & 0.33 & 0.13 \\
\hline Note: Mean - unweighted average inflation, SD - unweighted standard deviation, CV - \\
variation coefficient. \\
Source: Eurostat (2009), own calculations.
\end{tabular}

In the first years after launching the Euro (1999-2002) inflation rates across Euro area countries converged and variation was somewhat reduced. The spread, defined as the difference between the highest and lowest national inflation rate, increased in 2000 (over 4\%) and a reduction was observed during the second half of 2003 and at the beginning of 2004 (around 2\%). ${ }^{15}$ Then the next wave of variation came, but it was not so significant as in 2000 when strong US dollar and rising commodity prices may have been one of the influences that brought about relatively high

\footnotetext{
${ }^{14}$ COICOP is the abbreviations for Classification of individual consumption by purpose used by the Eurostat.

${ }^{15}$ The spread decreased dramatically during the 90 's, see Égert et al. (2004).
} 
dispersion of inflation. Significant reduction of dispersion was observed during 2006 and 2007 with the lowest value $1.5 \%$ (July 2007). The end of our sample was characterised by a rising range, but this increase was rather limited and, apart from 3 months in mid-2008, did not surpass 2.7\%. The main disadvantage of this unweighted measure is its high sensitivity to outliers (one small country with relatively low or high inflation rate).

\section{Figure 1: HICP Dispersion Measures in the Euro area (EA12), 1999-2008}

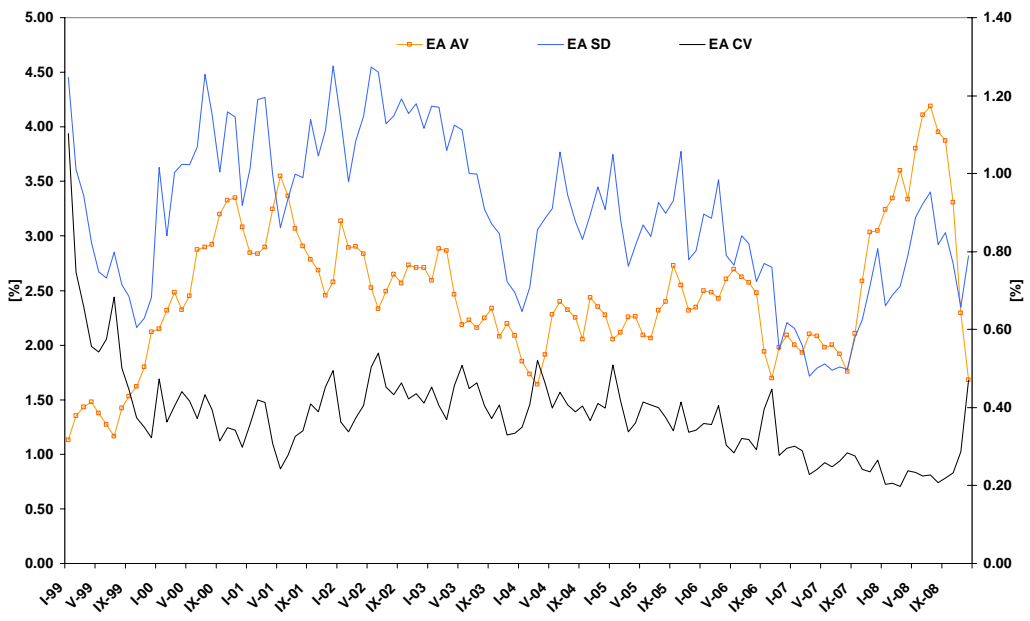

Note: EA AV - the EA12 unweighted average inflation (left axis), EA SD - the EA12 unweighted standard deviation (right axis), EA CV - the EA12 variation coefficient (right axis).

Source: Eurostat (2009), own calculation.

Standard deviation - as another simple measure - presents a very similar picture as the spread, but the level is different. After a reduction in 1999, it increased and remained stable within a narrow band around 1\% - with a drop at the end of 2003 - until the beginning of 2006 when it started decreasing and levelled out at around $0.5 \%$ in 2007 . This trend was interrupted in the second half of 2007 , but the $1 \%$ level was not reached. The spread between the minimum and maximum value of HICP inflation across euro area countries ${ }^{16}$, the range and the average inflation are depicted in Figure 2 (see below).

A relative measure of dispersion is the variation coefficient. ${ }^{17}$ An advantage of this measure is that inflation differentials usually increase during times of high inflation and standard deviation may be biased upwards (Égert et al., 2004.). ${ }^{18}$ The variation coefficient is adjusted from these scale effects. The relative smooth line seems to support the hypothesis of a positive link between mean inflation and inflation variation. The increase in inflation in 1999 or 2008 was connected only with a mild increase of variation, and the variation coefficient decreased after a spike and remained stable. There seems to be a structural change (level shift in 2003) when this measure achieved a new low in our time span. A similar change can be found in 2007 (due to rise in commodity and

\footnotetext{
${ }^{16}$ A particular interest may be devoted to the line showing movements of the minimum inflation rate among euro area countries. After subtracting this inflation from nominal interest rates of the ECB, it is obtained negative real interest rate. The minimum value has been marked in eight countries of the Euro area (EA12), the most often in Finland (35 months), Germany (31 months) and the Netherlands (17 months). It is also possible to think about implications for the new EU Member States, which are supposed to adopt the euro, stemming from the fact that some euro area countries have very low inflation.

17 Defined as standard deviation of inflation divided by mean inflation.

18 On the other hand, in case of very low inflation, the variation coefficient may increase beyond usual limits.
} 
agricultural prices). However, this development has been recently interrupted by the financial turmoil in the wake of the ongoing financial crisis that significantly reduced demand and has resulted in falling prices of these commodities. ${ }^{19}$

Figure 2: HICP Dispersion in the Euro area (EA12), 1999-2008

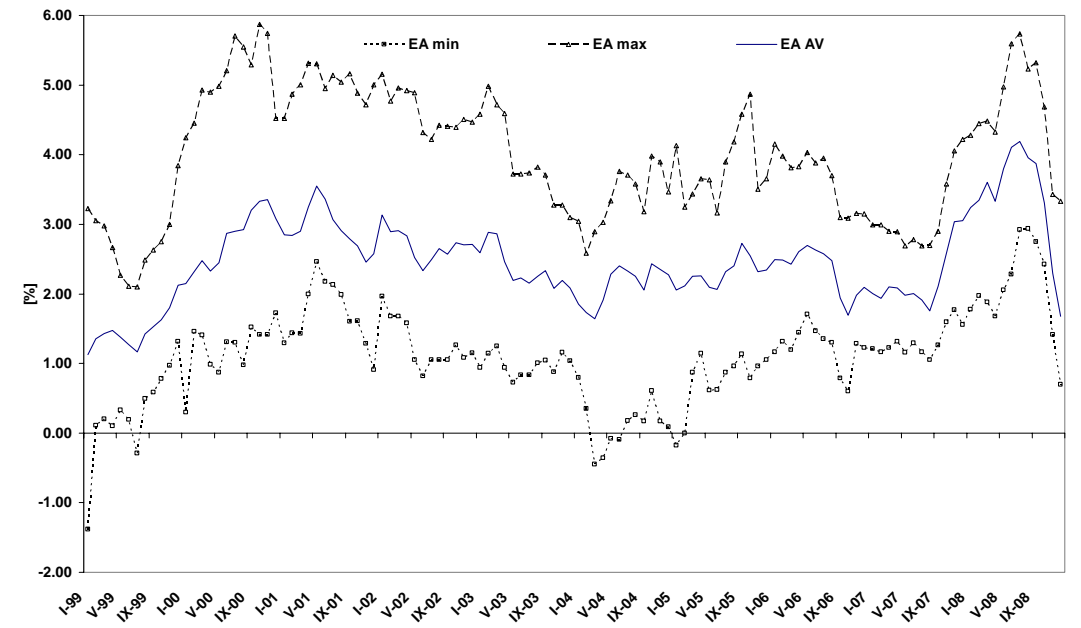

Note: EA min - the EA12 inflation rate (minimum), EA max - the EA12 inflation rate (maximum), EA AV - the EA12 unweighted average of inflation.

Source: Eurostat (2009), own calculation.

Because the unweighted measures may be influenced by small countries and their divergent numbers, it is convenient to complement the analysis by using weighted measures. This involves additional complications since the issue of choosing the right indicator for calculation of weights has to be dealt with. Égert et al. (2004) or Weber and Beck (2005) used nominal GDP. We prefer GDP valued in PPS $^{20}$ because these weights are adjusted for exchange rate and differences in prices and may offer a less distorted picture than weights based on nominal GDP. Even though the group of countries belonging to the Euro area is relatively homogeneous, the southern wing (Greece, Portugal, and Spain) has been persistently below the Euro area average. On the other hand, if nominal GDP is used, the impact of high income countries with relative high domestic price levels such as Ireland, Luxembourg, the Netherlands or Austria and Belgium would be overestimated. In this case their weights would be lower (higher) and this would assign them lower (higher) significance in the group measures than they should have had if we had used nominal GDP, and the bias is more important for lower income countries. ${ }^{21}$ In fact, these countries account for a relatively small part of the Euro area (around one third GDP in PPS), but their inflation rates influence the common measures of inflation dispersion.

Figure 3 illustrates the same development (the Euro area, 1999-2008) as Figure 1, but using weighted statistics instead (mean inflation, standard deviation and variation coefficient). The weighted measures should better reflect both country dimension and possible impact on the Euro

\footnotetext{
${ }^{19}$ A very similar picture is obtained when we analyze the group EA11 (without Greece).

20 Purchasing power standard is an artificial currency unit on the basis of euro, which expresses the average price level in the EU-25 countries.

21 The weights in PPS lie between $15.9 \%$ and $19.0 \%$ for the southern wing and between $14.3 \%$ and $15.0 \%$ for the high income countries. In the case of nominal GDP, the weights are between $12.9 \%$ and $16.4 \%$ a $14.6 \%$ and $15.8 \%$ respectively.
} 
area economy. The differences between the EA12 and the EA10 aggregates are not so large. ${ }^{22}$ The process of nominal convergence in the 90's has had positive impact on inflation and its volatility. In comparison with the unweighted statistics, the increase in 2000 was less pronounced and the peaks and troughs of inflation during our period are much flatter, apart from the latest spike in 2007. The weighted variation coefficient, which accounts for differences in economies and possible level shifts, does not show any significant divergence but there is again a shift in 2003 and in $2007 .^{23}$

\section{Figure 3: Weighted HICP Dispersion Measures in the Euro area (the EA12 and the EA10} groups), 1999-2008

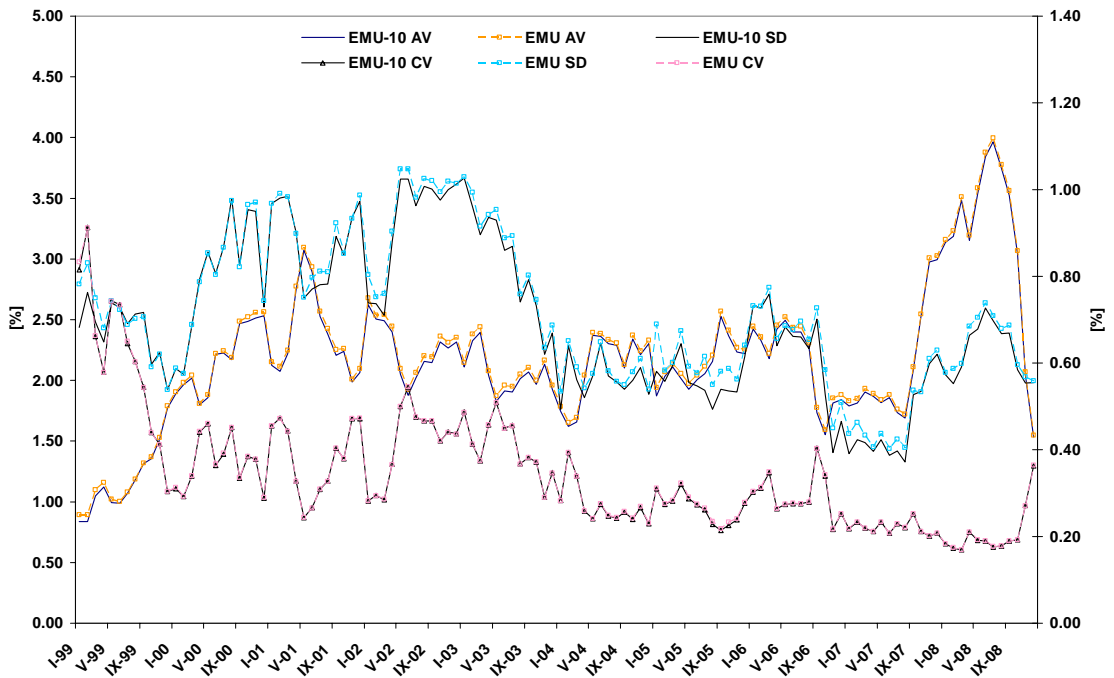

Note: EMU AV - the EA12 weighted average inflation (left axis), EMU SD - the EA12 weighted standard deviation (right axis), EMU CV - the EA12 variation coefficient (right axis). EMU-10 AV - the EA10 weighted average inflation (left axis), EMU-10 SD - the EA10 weighted standard deviation (right axis), EMU-10 CV - the EA10 variation coefficient (right axis).

Source: Eurostat (2009), own calculation.

Figure 3 shows the cross-country dispersion in HICP inflation in the Euro area for different specifications of the group. Relative high dispersion in the 90's was significantly reduced in the second half of this period with its minimum in mid-1997 (see Altissimo et al., 2005). ${ }^{24}$ Then a reverse trend started and, after a spike at the beginning of 1999 and a local minimum in the second half of 1999, the dispersion edged up in 2000 and 2001 to around 1.5\%. In 2003 the up-and-down movements in a narrow band $(1.0 \%-1.5 \%)$ were disrupted by a new trend resulting in a value of $0.53 \%$ in January $2004 .^{25}$ Afterwards, a new up-and-down movement came along, but the range was reduced $(0.6 \%-1.0 \%)$ in comparison with the previous one. A new reduction of dispersion began in early 2006 and then reached a minimum of $0.4 \%$ by the end of that year. This trend was

\footnotetext{
${ }^{22}$ The whole picture does not seem to be influenced by a group of included countries. Some studies preferred either the EA12 (for example ECB, 2003) or EA10 (for example Altissimo et al., 2005) for detailed analysis of inflation differentials.

${ }^{23}$ There is no significant difference of average inflation regarding the EA12 or the EA11 group of countries; apart from the fact that standard deviation was somewhat lower for EA11. This was also main reason why we analyses the EA12 and not the EA10 or the EA10 group of countries.

${ }^{24}$ This does hold for the EA10 group of countries, the EA11 and the Euro area (EA12) showed very similar patterns, but the reduction was less significant and more pronounced. It is not shown in Figure 4.

${ }^{25}$ Our results are similar to those described for example in Altissimo et al. (2005). Minor discrepancies are due to changes in the base year for the HICP and some revisions of the underlying time-series.
} 
discontinued due to the new spike in 2007. At the end of 2008 the dispersion stood at around 0.8. When looking at the EA11 and the EA12 groups, the picture is rather similar with some differences resulting from larger swings of inflation in Greece (included in the EA12), in particular in 2004-2006. Even the EA11 differentials followed very closely the EA10 differentials (without Greece and Luxembourg) and spreads between these values have been negligible over time. Therefore, the main factor seems to be connected with higher variability of inflation in Greece.

\subsection{Structural decomposition}

In this subsection we try to answer the following questions: Are inflation differentials in the Euro area more important compared with other monetary unions? What nature does inflation differentials in the Euro area have - are they sectoral phenomena (tradable vs. non-tradable)?

In Equation (1) we defined inflation rate for country $j$ and time $t$. The overall inflation differential $\delta_{t}^{j}$ between country $j$ and the Euro area for time $t$ is defined as:

$$
\delta_{t}^{j}=\left(\pi_{t}^{j}-\pi_{t}^{\text {euro }}\right)
$$

and the dispersion $\Delta_{t}$, measured by the root mean squared around the Euro area average, is denoted as:

$$
\Delta_{t}=\left(\frac{\sum_{j=1}^{N} \delta_{t}^{j 2}}{N}\right)^{1 / 2},
$$

where the denominator $N$ depends on the number of analyzed countries $(10,11,12$ or 13 and 15).

Because we use subindices the inflation rate for subindex $i$ of country $j$ for year $t$ is $\pi_{i, t}^{j}$, then the Euro area aggregate is $\pi_{i, t}^{\text {euro }}$. The inflation differential for subindex $i$ country $j$ and time $t$ with respect to the Euro area average $\delta_{i, t}^{j}$ is measured as:

$$
\delta_{i, t}^{j}=\left(\pi_{i, t}^{j}-\pi_{i, t}^{e u r o}\right),
$$

and the dispersion of inflation $\Delta_{i, t}$ for subindices $i$ is:

$$
\Delta_{i, t}=\left(\frac{\sum_{j=1}^{N} \delta_{j, t}^{j 2}}{N}\right)^{1 / 2} .
$$

Overall dispersion of inflation $\left(\Delta_{t}\right)$ is not calculated as the weighted average of the sectoral dispersions, but we follow Altissimo et al. (2005) and analyze the dispersion as the relative contribution of individual subindices. In order to calculate it, it has to be assumed that sectoral 
country weights (within the HICP index) are equal for the sample of countries $-\forall_{j} w_{i, j, t}=w_{i, t}$. We use the weights for 2008 and the Euro area for our empirical exercise (therefore $t$ is equal to 2008 $\left.-w_{i}=w_{i, 2008}=\forall_{t} w_{i, t}\right)$. The contribution of a sector $i$ to total inflation dispersion can be defined as:

$$
\frac{w_{i} \times \Delta_{i, t}}{\sum_{i} w_{i} \times \Delta_{i, t}} .
$$

Figure 4: Dispersion in HICP, the Euro area, y-on-y growth rate, 1999-2008

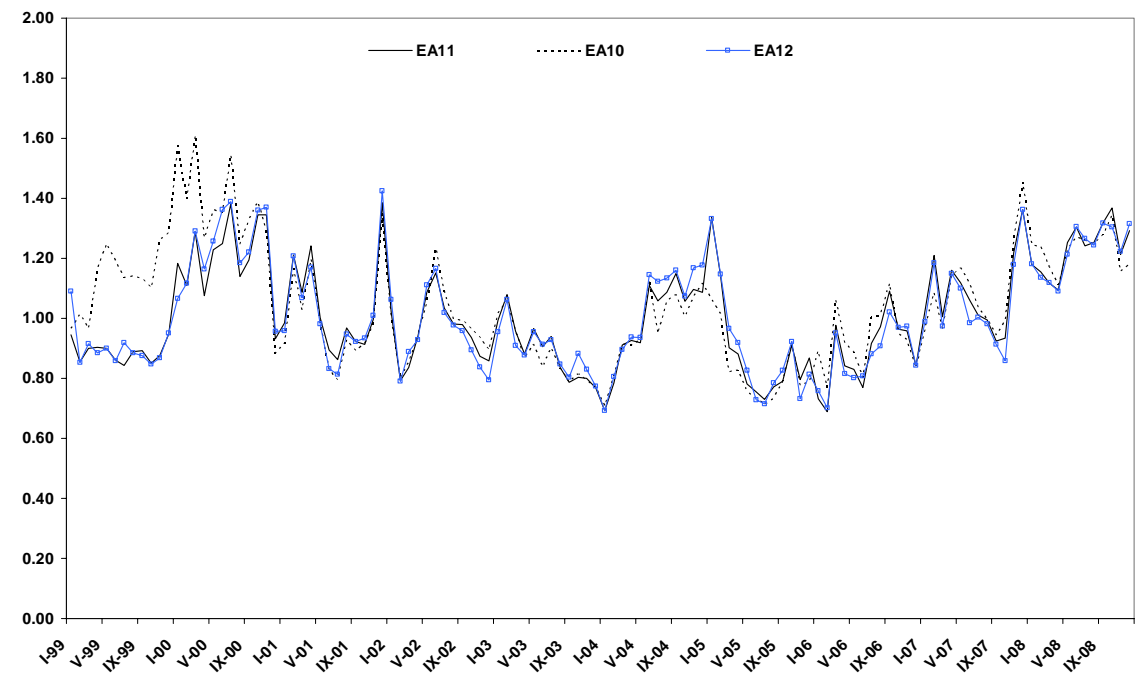

Note: EA12 - the Euro area, EA11 - the EA12 without Luxembourg, EA10 - the EA11 without Greece.

Source: Eurostat (2009), own calculation.

Decomposition of inflation variability is based on five subindices (their weights are shown in Table 2) and it can be used to explain sectoral influences on the overall dispersion of inflation. Corresponding charts are in the Appendix 3: Figure 1A to Figure 4A inclusive). They show dispersion of inflation rates resting upon five main sectors (Services, Industrial Goods, Energy, Processed and Unprocessed Food) within the overall HICP and the contributions of these individual sectors. Figure 4 shows how the aforementioned indices contributed to overall HICP inflation dispersion for there groups of Euro area countries.

Table 2: HICP weights, COICOP five subindices, the EA12, 2008

\begin{tabular}{|l|c|}
\hline Item & weight (\%o) \\
\hline Services (overall index excl. goods) & 409.29 \\
Non-energy industrial goods & 297.86 \\
Energy & 98.10 \\
Processed food & 118.36 \\
Unprocessed food & 76.01 \\
\hline Total & 1000.00 \\
\hline Note: The HICP weights are calculated for every year. \\
Source: Eurostat (2009).
\end{tabular}

Some implications of the decomposition used are worth mentioning. Prices of Services and 
the corresponding deflator of value added created by service sector are almost the same, prices of Industrial Goods include prices of imported (i.e. tradable) goods and prices of (non-tradable) services which have been used while goods being prepared for sale (see Altissimo et al., 2005). ${ }^{26}$ This might influence the impact of this sector on inflation dispersion.

In spite of the aforementioned problems, there are some conclusions that can be drawn from our analysis. The increased inflation in 2000-2002 was mainly due to the Services and Energy sectors. As Figure 1A shows, the dispersion of Services has surpassed that of the overall HICP in most years and Figure 2A confirms that the relative importance of this sector has increased against other subindices. ${ }^{27}$ Less significant was the impact of Energy because of its relative low weight in the HICP (around one fifth of the weight of Services). On the other hand, Industrial Goods excluding Energy has been loosing its importance (measured by its weight in HICP) with low dispersion. Conversely, in 2006 and 2007 its impact on dispersion gained some significance. The impact of Processed and Unprocessed Food subindices has remained limited; even though volatility in 2002 and in particular in 2004 was considerably high (their weights have been shrinking or levelling out later on.). A very special issue is connected with the Energy subindex, which has shown the highest volatility and despite low weight may be sealed as the main source of overall HICP dispersion.

\section{Table 3: HICP weights, COICOP 12 subindices, the EA12, 2008}

\begin{tabular}{|l|r|}
\hline Item & weight (\%o) \\
\hline Food and non-alcoholic beverages & 157.81 \\
Alcoholic beverages; tobacco & 37.19 \\
Clothing and footwear & 68.33 \\
Housing; water; electricity; gas and other fuels & 153.01 \\
Furnishings; household equip. and routine house maintenance & 70.09 \\
Health & 40.49 \\
Transport & 156.59 \\
Communication & 32.91 \\
Recreation and culture & 96.78 \\
Education & 10.42 \\
Restaurants and hotels & 92.76 \\
Miscellaneous goods and services & 83.61 \\
\hline Total & 1000.00 \\
Note: The HICP weights are calculated for every year. & \\
Source: Eurostat (2009). &
\end{tabular}

If we use the more detailed decomposition of the HICP (12 subindices), the overall picture is almost unchanged, but it is possible to see the main determinants of HICP index. Table 3 reports the weights, which were used for subindices in the Euro area HICP in 2008. We also calculated several composite indices, which represent main parts of household expenditures.

The subindex measuring price movements of food and Non-alcoholic Beverages importantly contributed to the dispersion in 1999, between 2002 and 2003 and in 2000 (in the

\footnotetext{
${ }^{26}$ For example prices of marketing services, prices for transporting, storing, delivering goods, etc. The Services subindex is a proxy for non-tradable sector in our article and this index may show the highest volatility - owing to the composition of this index covering different kinds of services - and thus the highest contribution to dispersion of overall HICP inflation.

${ }^{27}$ This is also verified by looking at the increase in the weight of Services in the HICP during this period. However, its maximum was reached in 2004.
} 
inverse direction pushing the dispersion lower). The price spike in 2007 and 2008 did not contributed so much due to more important influences stemming from other indices. The index has been less volatile since 2004. The subindex for Alcoholic Beverages and Tobacco showed a significant increase between 2003 and 2004, but due to its low weight its contribution to inflation dispersion was rather limited. While the subindex for Clothing and Footwear oscillated around the HICP index in our analysed period, the same does hold for the subindices Housing, Water and Energy and Fuels ${ }^{28}$, but one spike around 2000 and then again in 2005 contributed significantly to the dispersion of HICI inflation. The increase of fuel prices in 2006 and 2007 did not influence the dispersion significantly, because fuels have a very low weight in this subindex and even lower in the total HICP index. ${ }^{29}$ Relative high volatility showed the subindices Health and Education with some spikes, but their weights are negligible (around 5\% of the total HICP index) and therefore their contributions to dispersion of inflation were rather limited. ${ }^{30}$ Higher volatility was a characteristic pattern for the subindex Communication, but connected with the low importance of this subindex in HICP index, it was not one of the determinants of dispersion in HICP inflation. The subindex Miscellaneous Goods and Services that includes many different items showed high volatility too, in particular since 2004. It may be concluded that the subindices food and beverages, housing and goods and services connected with housing were the main drivers of inflation dispersion. Charts showing individual subindices and their contribution to the total dispersion of HICP inflation are in Appendix 4 (Figure 5A to Figure 10A inclusive).

\subsection{A comparison of U.S. regions and the Euro Area}

Having seen the dispersion of inflation across Euro area countries, one may ask whether these differences are a stylized fact in a monetary union or it is a particular problem of the Euro area. Due to the dimension of the Euro area (consisting of individual countries) a comparison can be made with another monetary union, namely the U.S.A. Angeloni and Ehrmann (2007) presented inflation differentials for the four US regions. The main problem is that inflation divergence among US regions is not directly comparable; in spite of this point some authors have used this for comparisons because there does not seem to be any other possibility. The most striking fact is that the 14 U.S. metropolitan areas (MSAs) ${ }^{31}$ are too small in comparison with Euro area countries and this may result in more volatile price indices, while the four main areas (U.S. Census regions) are too large in comparison with Euro area countries. For example Angeloni and Ehrmann (2007), Beck et al. (2006) or Fendel and Frenkel (2008) claim that the appropriate region would be somewhere in-between these aggregates and probably in the direction of U.S. Census regions. Due to the problem with data ${ }^{32}$ we used only data for every second month for three areas (Chicago, Los

\footnotetext{
${ }^{28}$ The same does hold true for the subindex Furnishings and Household Equipment and Maintenance or the subindices Transport, Recreation and Culture, Restaurant and Hotels.

${ }^{29}$ However, they influence production cost for goods and services and the pass-through seems to be more indirect.

${ }^{30}$ Some spikes may have been brought about changes of regulated or administrated prices, which are included in these subindices.

${ }^{31}$ The total number of metropolitan areas is 26 . However, for some areas are values available only for some periods or averages and yearly data. Therefore, we had to use the data only for 14 metropolitan areas: Atlanta, Boston, Chicago, Cleveland, Dallas, Detroit, Houston, Los Angeles, Miami, New York, Philadelphia, San Francisco, Seattle and Washington.

32 Data source Bureau of Labor Statistics (BLS) for the period from January 1999 to December 2008. The monthly indices are available only for three cities (Chicago, Los Angeles and New York), the data for the remaining cities are only every second month (biannual data). Data for Atlanta, Detroit, Houston, Miami, Philadelphia, San Francisco, and Seattle are released only in the even months, data for Boston, Cleveland, Dallas, and San Francisco only in odd months.
} 
Angeles, and New York) with full coverage. The basic statistics for the four U.S. regions are in Table 4, for the 14 U.S. metropolitan areas in Table 5 (see below).

\section{Table 4: Descriptive statistics for the U.S. regions I, 1999-2008}

\begin{tabular}{|l|c|c|c|}
\hline & mean & SD & CV \\
\hline North East & 0.99 & 2.73 & 0.36 \\
- North East A & 0.94 & 2.78 & 0.34 \\
- North East BC & 1.23 & 2.65 & 0.47 \\
\hline Mid West & 1.32 & 2.29 & 0.58 \\
- Mid West A & 1.30 & 2.24 & 0.58 \\
- Mid West BC & 1.34 & 2.30 & 0.58 \\
- Mid West D & 1.64 & 2.44 & 0.67 \\
\hline South & 1.30 & 2.52 & 0.51 \\
- South A & 1.19 & 2.74 & 0.44 \\
- South BC & 1.40 & 2.36 & 0.59 \\
- South D & 1.35 & 2.52 & 0.53 \\
\hline West & 1.17 & 2.56 & 0.46 \\
- West A & 1.12 & 2.88 & 0.39 \\
- West BC & 1.35 & 2.32 & 0.58 \\
\hline US average & 2.64 & 0.70 & 0.27 \\
\hline Note: A, BC and D are abbreviations for population of regions included in the aggregate: A-more than 1.5 \\
mil., BC - between 0.05 and 1.5 mil., D - less than 0.05 mil. Mean - unweighted average inflation, SD - \\
unweighted standard deviation, CV - variation coefficient. \\
Source: Table 3, own calculations.
\end{tabular}

The average inflation for the 4 U.S. regions has been around 2.8 percent (see Figure 5). The dispersion, minimum and maximum values have been within a relatively narrow band - in some month approached 6 percent (maximum 5.66\%) or close to zero for some regions and some months (and the minimum was reached in December $2008-0.32 \%$ ). Inflations rates typically varied between 2 and 4 percent (modus was around 3.1 percent). The average inflation for the euro area countries has been around 2.5 percent. The dispersion and minimum and maximum values have been within a relatively broad band - in some month approached 6 percent (maximum 5.87\%) or were significantly below zero (minimum $-1.38 \%$ ) for some euro area countries and some months. Inflations rates usually varied between 1 and 4 percent (modus was around 2 percent). It may be pointed out that the modus inflation rate for the Euro area is around $2 \%$, for the U.S. regions around $3 \%$ (see Figure 6).

An analysis of inflation in the 14 U.S. metropolitan areas can be found for example in Bick and Nautz (2008). 
Figure 5: Dispersion of US inflation, the 4 U.S. Census regions, 1999-2008 (left) and some measures of dispersion of US inflation, the 4 U.S. Census regions, 1999-2008 (right)

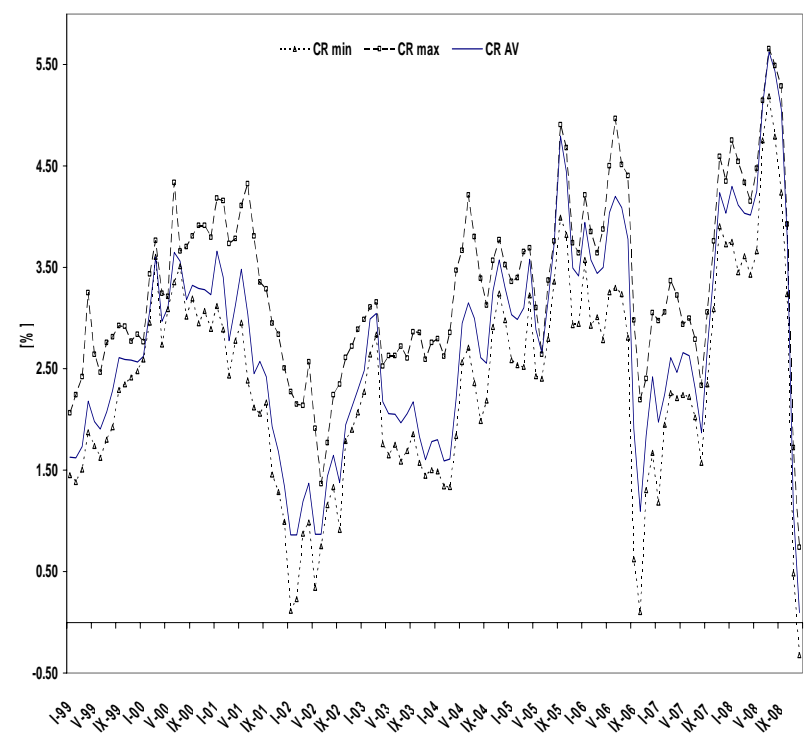

Note: CR - 4 U.S. Census regions, CR min - the inflation rate (minimum), CR max - the inflation rate (maximum). All statistics are unweighted.

Source: BLS (2009), own calculations.

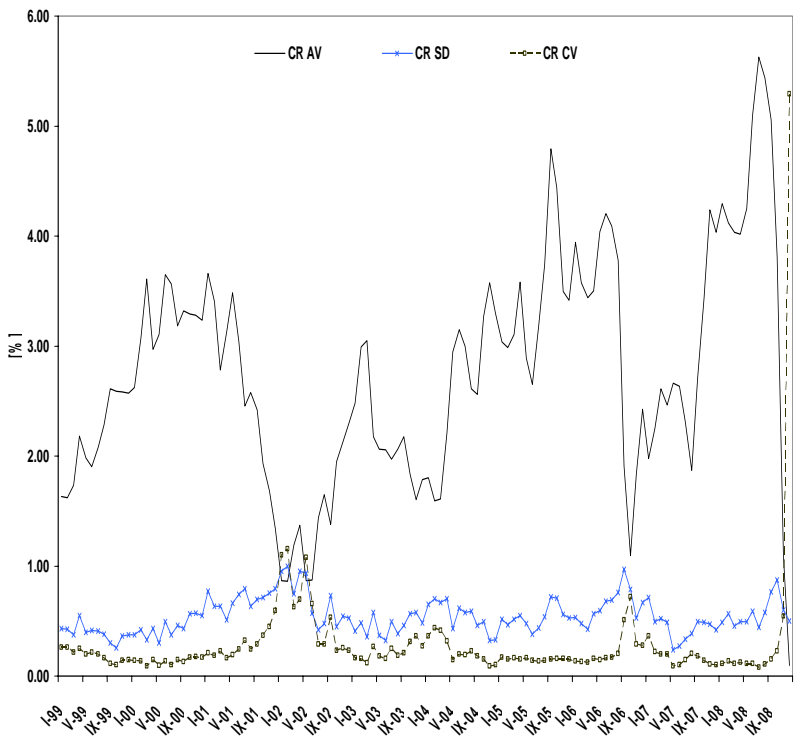

Note: $\mathrm{CR}-4$ U.S. Census regions, CR AV - average, CR SD - standard deviation, $\mathrm{CR} \mathrm{CV}$ - variation coefficient. All statistics are unweighted.

Source: BLS (2009), own calculations.

The distribution of inflation rates in the Euro area and the 4 U.S. Census regions is illustrated in Figure 6. These figures reveal some additional information about the distribution of inflation differentials over the last ten years. Both distributions are shifted to the right, i.e. the majority of inflation rates were above zero. For the US regions 25 percent of observed inflation differentials were below 2.06 or above 3.46 percent, for the euro area countries 25 percent were below 1.73 or above 3.15 percent.

Table 5: Descriptive statistics for the U.S. regions II, 1999-2008

\begin{tabular}{|l|c|c|c|}
\hline & mean & SD & CV \\
\hline Atlanta & 2.34 & 0.87 & 0.37 \\
Boston & 3.13 & 0.85 & 0.27 \\
Chicago & 2.50 & 0.65 & 0.26 \\
Cleveland & 2.41 & 0.96 & 0.40 \\
Dallas & 2.47 & 0.98 & 0.40 \\
Detroit & 2.46 & 0.54 & 0.22 \\
Houston & 2.38 & 1.13 & 0.47 \\
Los Angeles & 2.97 & 0.90 & 0.30 \\
Miami & 3.07 & 1.28 & 0.42 \\
New York & 2.88 & 0.73 & 0.25 \\
Philadelphia & 2.66 & 0.91 & 0.34 \\
San Francisco & 3.02 & 1.21 & 0.40 \\
Seattle & 2.96 & 0.93 & 0.31 \\
Washington & 2.71 & 0.98 & 0.36 \\
\hline US average & 2.64 & 0.70 & 0.27 \\
\hline Note: Mean - unweighted average inflation, SD - unweighted standard deviation, CV - \\
variation coefficient. Source: BLS (2009), own calculations.
\end{tabular}


The dispersion of inflation in the Euro area has been higher in comparison with regional differentials in some euro area countries. ${ }^{33}$ Only for comparison we added figures for the new members of the Euro area (without those for Slovakia that joined the Euro area in January 2009). ${ }^{34}$ However, if we compare the dispersion in the whole Euro area with the dispersion observed in the US (measured by unweighted standard deviation), the result is quite favourable. The dispersion among US cities has been constant around $0.7 \%$ since 1999 for MSAs (or around 0.5\%, but somewhat more volatile for U.S. Census regions). ${ }^{35}$

Table 6: Inflation differentials - the Euro Area and the U.S. I., 1999-2008

\begin{tabular}{|c|c|c|c|c|c|c|c|c|c|c|c|c|c|}
\hline & & 1999 & 2000 & 2001 & 2002 & 2003 & 2004 & 2005 & 2006 & 2007 & 2008 & SD & $\mathrm{AD}$ \\
\hline \multirow{15}{*}{ 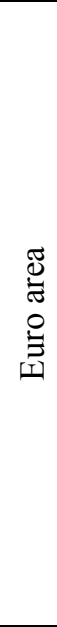 } & Austria & -0.1 & -0.6 & -0.2 & -0.6 & -0.7 & -0.2 & -0.6 & -0.3 & -0.4 & -0.1 & 0.37 & 0.39 \\
\hline & Belgium & -0.3 & -0.5 & -0.1 & -1.0 & -0.3 & -0.4 & -0.5 & -0.2 & -0.0 & -1.1 & 0.57 & 0.44 \\
\hline & Finland & -0.5 & -0.4 & -0.3 & -0.5 & -0.7 & -2.2 & -1.1 & -0.7 & -1.1 & -1.8 & 1.11 & 0.93 \\
\hline & France & -0.4 & -0.7 & -0.6 & -0.1 & -0.4 & -0.0 & -0.5 & -0.2 & -0.3 & -0.4 & 0.32 & 0.36 \\
\hline & Germany & -0.4 & -0.3 & -0.6 & -1.1 & -0.9 & -0.1 & -0.1 & -0.5 & -0.0 & -0.4 & 0.37 & 0.47 \\
\hline & Greece & -0.6 & -1.1 & -1.4 & -1.2 & -1.1 & -0.7 & -1.2 & -1.2 & -0.8 & -0.6 & 0.31 & 1.00 \\
\hline & Ireland & -2.1 & -2.1 & -2.2 & -2.2 & -1.0 & -0.0 & -0.3 & -1.0 & -0.1 & -0.3 & 1.07 & 1.13 \\
\hline & Italy & -0.4 & -0.3 & -0.2 & -0.6 & -0.6 & -0.0 & -0.1 & -0.2 & -0.3 & -0.8 & 0.33 & 0.33 \\
\hline & Luxembourg & -0.6 & -1.7 & -1.1 & -0.5 & -0.4 & -1.1 & -1.2 & -0.3 & -1.2 & -0.9 & 0.91 & 0.90 \\
\hline & Netherlands & -0.2 & -0.4 & -3.0 & -0.9 & -0.4 & -1.1 & -0.2 & -0.2 & -1.5 & -0.1 & 1.22 & 0.79 \\
\hline & Portugal & -0.0 & -1.3 & -1.8 & -1.6 & -0.3 & -0.2 & -0.3 & -0.6 & -0.3 & -0.7 & 0.84 & 0.73 \\
\hline & Spain & -1.0 & -1.5 & -0.4 & -1.7 & -0.7 & -0.9 & -1.5 & -0.8 & -1.2 & -0.1 & 0.54 & 0.97 \\
\hline & Cyprus & -1.8 & -1.2 & -0.0 & -0.8 & -0.3 & -1.5 & -0.8 & -0.4 & -0.7 & -0.2 & 0.83 & 0.77 \\
\hline & Malta & -2.6 & -1.5 & -1.5 & -0.2 & -0.5 & -0.5 & -1.1 & -1.2 & -0.0 & -3.3 & 1.55 & 1.22 \\
\hline & Slovenia & -6.0 & -6.0 & -4.8 & -4.6 & -2.7 & -0.9 & -0.2 & -1.0 & -2.5 & -0.2 & 2.32 & 2.90 \\
\hline \multirow{4}{*}{ 孞 } & North East & -0.2 & -0.1 & -0.0 & -0.5 & -0.9 & -0.3 & -0.1 & -0.4 & -0.2 & -0.7 & 0.32 & 0.36 \\
\hline & Mid West & -0.2 & -0.1 & -0.5 & -0.3 & -0.2 & -0.2 & -0.2 & -0.8 & -0.3 & -0.4 & 0.32 & 0.34 \\
\hline & South & -0.2 & -0.4 & -0.4 & -0.1 & -0.2 & -0.0 & -0.3 & -0.1 & -0.3 & -0.1 & 0.28 & 0.20 \\
\hline & West & -0.1 & -0.5 & -1.0 & -0.2 & -0.4 & -0.1 & -0.4 & -0.5 & -0.1 & -0.1 & 0.44 & 0.37 \\
\hline
\end{tabular}

Note: The differences are calculated as $\left\{\left[\ln x_{t}^{i}-\ln x_{t-12}^{i}\right]-\left[\ln x_{t}^{j}-\ln x_{t-12}^{j}\right]\right\}$, where $i$ are countries/regions numbers, $j$ are numbers for the groups (the EA12 average and the U.S. average). SD - unweighted standard deviation, $\mathrm{AD}$ - unweighted average absolute deviation: $\frac{1}{N} \sum_{j=1}^{N}\left|\pi_{t}^{j}-\pi_{t}^{\text {euro }}\right|$.

Source: BLS (2009); Eurostat (2009), own calculations.

As a next step, we added standard deviations and average absolute deviations of inflation so that one could easily compare the nature of inflation differentials (see an overview in Table 6 or grouped results in Table 7). The standard deviation measures volatility of inflation differentials and the absolute mean average shows differences against the EA12 average. It can be seen that some countries have not shown many changes (they have kept having lower or higher rates of inflation), but their average is significantly above the average. If the number of years with inflation above the

\footnotetext{
33 For example Angeloni and Ehrmann (2007) mentioned regions in some countries (Germany, Italy, and Spain).

34 The most interesting is the significant reduction of high inflation differentials in Slovenia and a spike in 2008 after the Euro adoption.

35 The significant drop in inflation rate resulted in other extreme, which reveals one of the problems of simple statistical measures - for very low values the variation coefficient increases over all limits (because the average inflation in U.S. regions is close to zero value), for discussion see for example ECB (2003). This problem emerged while analyzing the 14 U.S. metropolitan areas that have showed higher volatility of inflation.
} 
EA12 average are compared, it may be seen the similarity of U.S. regions (the only outlier seems to be the Mid West regions) or a similar pattern for some Euro area countries: there are three groups countries with positive differentials for the most years of our time span such as Ireland, Italy, Luxembourg, the Netherlands, Portugal or Spain, or even for all years - Greece, countries with negative differentials such as Austria, France and Germany and countries with similar numbers of both years. More striking are the differences by looking at the number of changes (i.e. situation when the sign of inflation differential has changed). These numbers are equal to three apart from the Mid West region and South region in the U.S., the variability for Euro area countries is in six cases equal to two, with countries that showed three or four changes or only one change or no change at all.

\section{Figure 6: Distribution of inflation rates, the Euro area (left) and the U.S. regions (right),} 1999-2008
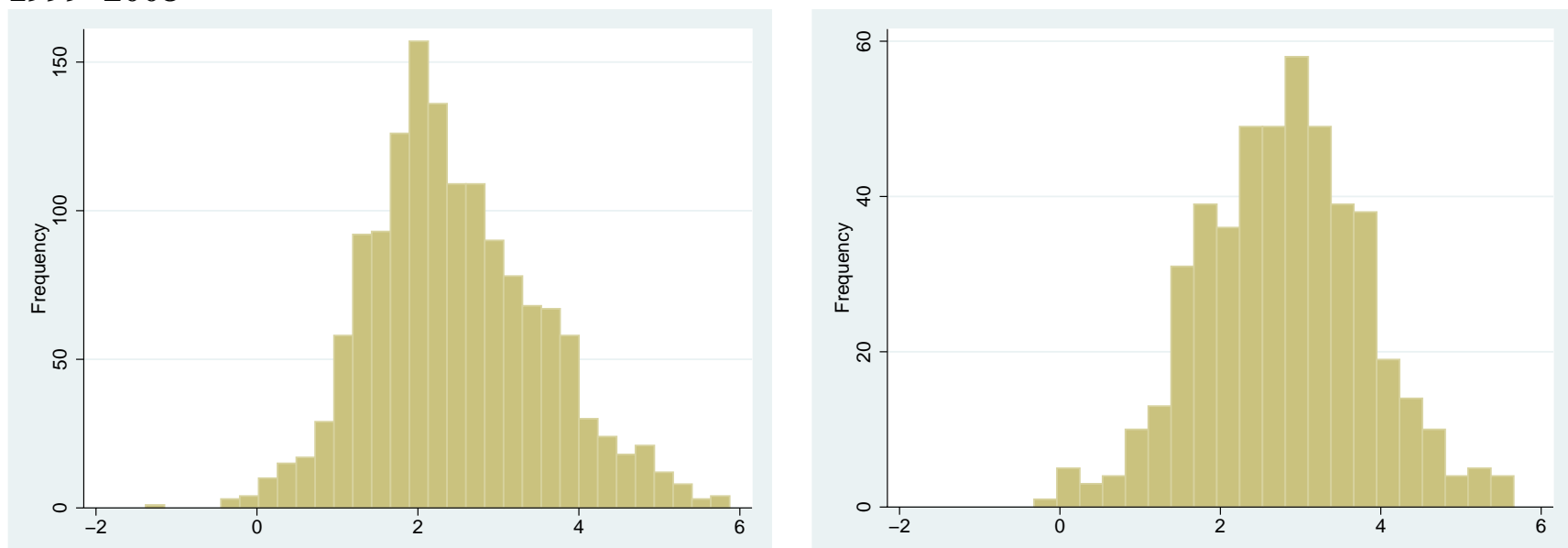

Note: the Euro area - inflation rates for 12 countries (left picture), the U.S. regions - the 4 U.S. Census regions (right picture). The yearly inflation rates for regions (countries) from January 1999 to December 2008 (1 440 observation for the Euro area, 480 observations for the U.S. regions). Source: BLS (2009), Eurostat (2009), own calculations.

So far we have discussed the issue of inflation persistence in the Euro area. Table 3 illustrates that differences in inflation have tended to be more stable, persistent and larger in Euro area countries (for example only positive value of inflation differentials have been recorded in Greece and apart from the year 2008 in Ireland and Spain; conversely, only negative values in Germany and with one year exemption in Austria and France). As noted by Cecchetti et al. (2002) or ECB (2003), inflation differentials may be viewed as one pattern of the Euro area. Conversely, the U.S. has shown more rapid changes of inflation differentials between years and the differentials have been rather smaller in relative terms. Only for comparison we added the figures for new member states which have joined the Euro area in recent years. One can see the differential and that there was no smooth process of convergence towards the Euro area average, for example in Slovenia a real convergence process started around the year $2002 .^{36}$

\footnotetext{
${ }^{36}$ Slovenia endorsed and then realized very special measures in coordination with the Bank of Slovenia: firstly they stabilized the exchange rate of national currency (the Slovenian tolar against the euro, see for example Weyerstrass, 2008), secondly, government kept using measures such as informal agreements with main labour unions (Slovenian labour market is highly unionized), limited increases of administered prices, counter-cyclical adjustment of excise duties on fuels, changes of foreign trade regimes (see for example IMAD, 2007) so that it could fulfill the Maastricht convergence criterion (inflation rate).
} 
Table 7: Inflation differentials - the Euro Area and the U.S. II., 1999-2008

\begin{tabular}{|l|c|c|c|}
\hline & + & - & changes \\
\hline Austria & 2 & 8 & 4 \\
Belgium & 6 & 4 & 2 \\
Finland & 4 & 6 & 2 \\
France & 1 & 9 & 2 \\
Germany & 1 & 9 & 2 \\
Greece & 10 & 0 & 0 \\
Ireland & 8 & 2 & 3 \\
Italy & 8 & 2 & 4 \\
Luxembourg & 8 & 2 & 3 \\
Netherlands & 5 & 5 & 2 \\
Portugal & 7 & 3 & 2 \\
Spain & 9 & 1 & 1 \\
\hline Cyprus & 8 & 2 & 2 \\
Malta & 5 & 5 & 8 \\
Slovenia & 10 & 0 & 0 \\
\hline North East & 6 & 4 & 3 \\
Mid West & 2 & 8 & 1 \\
South & 4 & 6 & 6 \\
West & 5 & 5 & 3 \\
\hline
\end{tabular}

Notes: +- means the number of years with inflation above the EA12 average, - - means the number of years with inflation below the EA12 average, changes - the number of changes of sings.

Source: Table 6, own calculations.

\section{Model and Data}

There are different approaches regarding empirical methodology in the literature (see Section 2). We follow the one suggested in Honohan and Lane (2003) which emphasized the role of key macroeconomic variables when searching for an explanation of observed inflation differentials: the role of exchange rate, phase of an economic cycle (measured by the output gap), fiscal policy, and a proxy for price level in the economy. Honohan and Lane (2003) and Honohan and Lane (2004) focus on the impact of the aforementioned variables in a panel of Euro area countries using yearly and quarterly data over 1999-2001 and 1999-2003 respectively. Our longer time span covers years from 1999 to 2007 . It enables us to assess the impact of exchange rate movements and price convergence that may be very important for catching-up countries, which may be somewhat difficult having shorter spans due to possible lags in underlying transmission channels.

To start with, the general specification in Honohan and Lane (2003) for inflation differentials takes this form:

$$
\pi_{i, t}-\pi_{t}^{E}=\beta\left(z_{i, t}-z_{t}^{E}\right)+\delta\left(\left[P_{i, t-1}-P_{i, t-1}^{\mathfrak{̊}}\right]-\left[P_{i, t-1}^{E}-P_{i, t-1}^{E ̊ ̊ ̊}\right]\right)+\varepsilon_{i, t}
$$

where $\pi_{i, t}$ and $\pi_{t}^{E}$ are the national and Euro area inflation rates, $z_{i, t}$ and $z_{t}^{E}$ represent the domestic and Euro area variables having impact on the inflation rate, $P_{i, t}$ and $P_{t}^{E}$ are the national and Euro area price levels and $P_{i, t-1}^{\AA ̊}$ and $P_{t-1}^{E \AA ̊}$ denote the national and Euro area equilibrium price levels.

The Euro area is supposed to be a convergence club where trade flows and institutions should reduce income and productivity differentials in the course of time. This leads Honohan and 
Lane (2003) to assume a common long-run national and Euro area price level. This simplifying assumption allows us to rewrite (7) in the following form

$$
\pi_{i, t}-\pi_{t}^{E}=\beta\left(z_{i, t}-z_{t}^{E}\right)+\delta\left(P_{i, t-1}-P_{i, t-1}^{\stackrel{̊}{a}}\right)+\varepsilon_{i, t}
$$

Equation (8) can in turn be rewritten as

$$
\pi_{i, t}=\psi_{t}+\beta z_{i, t}+\delta P_{i, t-1}+\varepsilon_{i, t}
$$

where term $\psi_{t}$ represents the time dummies. The main function of the time dummies $\left(\psi_{t}\right)$ in (8) is to capture the common movements in inflation.

Defining the vector of variables $Z$ according to Honohan and Lane (2003) allows us to compare our results with the previous studies, thus $z=\left(\Delta N E E R_{i, t-1}, G A P_{i, t}, F I S C_{i, t}\right)$, where $\triangle N E E R_{i, t-1}$ is the lagged change of nominal effective exchange rate, GAP $P_{i, t}$ represents the output gap, $F I S C_{i, t}$ denotes the cyclically-adjusted fiscal deficit and $P_{i, t}$ is the lagged comparative price level. ${ }^{37}$ Having this specification, we can write equation (9) as

$$
\pi_{i, t}=\psi_{t}+\beta_{1} \Delta N E E R_{i, t}+\beta_{2} G A P_{i, t}+\beta_{3} F_{I S C} C_{i, t}+\delta P_{i, t-1}+\varepsilon_{i, t}
$$

Therefore, the regression should explain inflation differentials across Euro area countries as idiosyncratic national movements. Regarding the coefficients and their signs in our regression, the coefficient $\delta$ is expected to be negative because of the link between lower price level and higher rate of inflation (as a result of nominal convergence in case of a monetary union, where the exchange rate channel is closed). ${ }^{38}$ Because movements of exchange rate may slow down inflation rate, one can expect a negative sign for parameter $\beta_{1}$. Closing of an output gap, i.e. a (robust) economic growth creates inflationary pressures, thus the sign of the parameter $\beta_{2}$ is expected to be positive. Fiscal stance (e.g. deficit) increases aggregate demand and may be associated with higher inflation rates (with or without impact on output gap) and vice versa, this leads to an assumption of a negative sign of the parameter $\beta_{3}$. Equation (10) was estimated by two-step Generalized Method of Moments (GMM), using lagged values of endogenous variables as instruments. We rely on this method because of the potential endogeneity of some variables to inflation rate in our model, namely output gap and fiscal balance.

The next section shows the results both for annual and quarterly data. We used three different databases for the analysis, two for the annual regressions (OECD database plus HICP data for the sake of comparison with previous studies such as Honohan and Lane (2003) and Eurostat database) and one for the quarterly (Eurostat). The main problem with quarterly data is that some variables are only available at an annual frequency, namely fiscal deficit and comparative price

\footnotetext{
${ }^{37}$ The comparative price level is the price level for Household Final Consumption Expenditure (HFCE) whose values are similar to the price level for Final Consumption Expenditures. We use the Eurostat dataset covering all the EU countries and partially our own calculations.

${ }^{38}$ The change of comparative price level can be influenced by two factors: higher domestic inflation compared with other countries or changes of an exchange rate, see for example Lewis (2007) or Žd'árek (2008) related to new EU Member States. Some threats and challenges for these states aiming at the euro adoption associated with the on-going financial crisis are mentioned in Dainau, Lungu (2009).
} 
level. Therefore, a quarterly observation has to be created from the corresponding yearly observation. In order to achieve this, we used the standard procedure for interpolation - the quadratic match procedure. ${ }^{39}$ Also for the quarterly series, output gap is obtained after generating the series for potential output using the Hodrick-Prescott filter with a smoothing parameter of 1600. Due to end-of-sample bias in the HP Filter used for the construction of the output gap, quarterly regressions cover up to the last quarter of 2007. Although it is possible to raise some doubts regarding the reliability of the results obtained from these interpolated series, quarterly data leads to higher degrees of freedom, which may be viewed as an advantage.

\section{Results}

In order to assess the robustness of results we consider different measures of inflation. For the OECD data this implies the following measures: HICP (total index), HICP excluding Energy, HICP excluding Energy and Unprocessed Food, Wages, GDP Deflator, Total Domestic Expenditure Deflator and Private Final Consumption Expenditure Deflator. In the case of Eurostat data, the inflation measures considered were: HICP (total index), HICP excluding Energy, HICP excluding Energy and Unprocessed Foods, Labour Cost Index, GDP Deflator based on national currencies and GDP Deflator based on Euro.

Results are summarized in the Appendices A and B in Table 1A to Table 12A inclusive. Table 1A shows the results of OLS estimates for OECD data for different group specifications of the Euro area. Since output gap and fiscal balance can be endogenous to inflation, the remaining tables focus on the GMM estimates of the different databases (OECD, Eurostat annual and Eurostat quarterly $)^{40}$, where these two variables are instrumented by their lagged values.

The OLS estimates in Table 1A show mixed evidence depending on the group considered. In the case of EA10 support is found for price level convergence in the three HICP measures of inflation. This evidence vanishes once we consider an expanded Euro area; both EA11 and EA12 show no statistically significant variables. On the other hand GMM estimates for OECD data (Table 2A) show a statistically significant output gap across all HICP measures and all Euro area specifications with the expected positive sign. Price level convergence is only found significant for the EA10 specification and for the alternative HICP measures.

The regressions with the Eurostat annual database show a similar picture for the aggregates EA10, EA11 and EA12 but not so much for the two remaining aggregates. Overall there is widespread support for the role of the output gap, which is statistically significant at the $1 \%$ level across all models and almost all group specifications (the effect for EA13 and especially EA15 is slightly weaker). Price level convergence is again found highly significant for HICP measures of the EA10 group and slightly less significant for the two core measures of HICP (excluding Energy and Energy and Unprocessed Food) in the case of EA15. The nominal effective exchange rate is found statistically significant but with an almost negligible effect in the GDP deflator specifications of EA10. As price level convergence, nominal effective exchange rate is found significant for the EA15 specification with the core measures of HICP. The overall evidence for the fiscal variable is disappointing, being rarely significant and with opposite-than-expected sign when found significant. This fragility is also encountered in Honohan and Lane (2003), who state that most of the impact of the fiscal variable is channelled through the output gap variable.

Finally, Table 6A and Table 8A show the quarterly estimates with one and four lags

\footnotetext{
39 See Fernández (1981) for a discussion of interpolation methods.

40 Analogous tables for OLS are available on request.
} 
respectively. In the one lag specification, output gap is found statistically significant across groups EA10, EA11 and EA12 but only when the labour cost index is used as dependent variable. The fiscal variable comes out significant across some models and group specifications but, as in the previous regressions, it shows the wrong sign so we do not dwell on this result. The nominal effective exchange rate is statistically significant once we expand the Euro area specification, in particular for EA13 and EA15 and for the three HICP measures. Strong evidence for price level convergence is found across groups, in particular for the GDP deflator measures of inflation. As expected, for the expanded specifications of Euro area groups this evidence in favour of price level convergence applies also to the two core inflation measures and the labour cost index. The evidence from the quarterly estimation with four lags is particularly inconclusive: no variable is significant across groups and/or specifications. While evidence in favour of output gap is overwhelming for EA10, it is inexistent for other group specifications. The aforementioned problem with the fiscal variable is still relevant here. For the nominal effective exchange rate and price level convergence there is only some weak evidence in groups EA15 and EA11 respectively.

The overall results point to the relevance of cyclical factors ${ }^{41}$ and to a lesser extent real convergence factors, since national output gaps come out as the most relevant variable in explaining inflation differentials in the Euro area, followed by a relatively weaker but still non-negligible price level convergence effect. Nevertheless the coefficients for the output gap are somewhat smaller than in previous studies (lying between 0.005 and 0.013 ). For our proxy for the process of price level convergence the coefficients lie between -0.02 and $-0.05 .{ }^{42}$

As opposed to Honohan and Lane (2003) and Honohan and Lane (2004), almost no support is found for the nominal effective exchange rate, a result that can be explained by the extension of the time span used for the analysis ${ }^{43}$. In the wake of this result, it is possible to state that after almost ten years of common currency, exchange rate movements have a diminished impact on inflation differentials, which in turn implies that the policy concern of minimizing the impact of real exchange rate overshooting becomes a second order concern.

As a robustness check we exclude the variable fiscal balance. The results for annual and quarterly data estimated by the GMM method are slightly changed (they are shown in Appendix Table 6A to Table 9A inclusive). Output gap is highly significant and the variable NEER is insignificant. The only change is that the variable (a proxy) for price convergence turns to be significant (at 10 per cent level) for some specifications. ${ }^{44}$ We further explored including other variables that may have impact on inflation differentials: GDP per person employed as a measure of productivity and GDP per capita as a measure of income level. Nevertheless both variables were not significant across different specifications or group of countries. ${ }^{45}$

We also tried as a sensitivity check to drop one country at a time for GMM method and total HICP index (results are in Appendix, Table 12A). ${ }^{46}$ Output gap is highly positive and other

\footnotetext{
${ }^{41}$ A result that is somewhat in line with Hofmann and Remsperger (2005).

${ }^{42}$ For example, a coefficient of -0.05 implies that a country with a price level $20 \%$ below the Euro area average is likely to experience inflation $1 \%$ above the area average.

${ }^{43}$ This result is also expected by these authors, who view the effect of effective exchange rates as temporary.

${ }^{44}$ The picture change if one looks at the results for the Euro area consisting of the three new members - then the lagged value (one lag) of the NEER is highly significant. These results are similar to those obtained for full specification.

${ }^{45}$ The results are slightly changed - results for GMM and yearly data are not reported here but are available upon request).

${ }^{46}$ We report results for yearly data (Eurostat), total HICP index and GMM method. Stability of our results is also confirmed when we use OECD data which are not reported in this study.
} 
variables are insignificant. Exclusion of Ireland leads to significance of the proxy for price level convergence. A reason may be that the relative high price levels in Ireland and Luxembourg being together in the regression may reduce significance of this variable. Otherwise, our results are relatively stable: estimates of coefficient or variation of t-statistics are slightly changed for the output gap (highly significant), NEER and price level (CPL) remain insignificant across specifications, being the exclusion of Ireland (CPL is positive). The variable which varies is the proxy for fiscal policy (different level of significance) and when dropping three countries (France, Ireland, and Luxembourg) it turns to be insignificant.

As a next robustness check we include productivity (AMECO database) defined as gross value added at 2000 prices per person employed in relation to the EA12 average (for industry excluding building and construction) ${ }^{47}$ and income level (GDP per capita, Eurostat data) that may have impact on inflation differentials. Both variables are in levels and we used not only current year, but also one lag variables which may influence the long-run equilibrium price level. We employ only GMM method, three different HICP measures and Eurostat (yearly data). ${ }^{48}$ While labour productivity is not significant across different specifications or group of countries, GDP per capita is significant for some specifications (the total HICP index) and groups of countries. We also investigate the impact of excluding the fiscal variable. The results are reported in Appendix, see Table 10A and Table 11A.

\section{Conclusions}

In this paper we studied inflation differentials in the Euro area and their determinants. We follow one of the two main approaches that can be found in the literature on the subject, namely a descriptive analysis backed by panel regressions.

Regarding the descriptive analysis, we first studied the dynamics of inflation using unweighted measures (mean, standard deviation and variation coefficient), and then switched to weighted. Secondly, we studied the decomposition of the total HICP index based on five main subindices and then twelve main subindices corresponding to the COICOP classification. Inflation differentials in the Euro area seem to be a characteristic pattern of the monetary union and they tend to be significant and long-lasting. As the main drivers of dispersion can be marked the Services sector (a proxy for non-tradable sector), which contributed to the dispersion of inflation in an important way. Conversely, some sectors that can be referred to as tradable (industrial goods apart from energy) seem to have relatively low power in determining and explaining dispersion of prices. The more detailed analysis based on twelve subindices revealed that highly volatile indices are those that do have relative low weight in the HICP index (such as Communications) and/or cover prices of goods and services that are regulated (administered - for example Health or Education) and an adjustment of those prices, if it is linked to other tendencies may result in significant dispersion of inflation. We found in this detailed analysis that among the main drivers were the Food and beverages and the Housing, Furnishing and goods and services appertained to these subindices.

A brief comparison between the Euro area and U.S. regions only confirmed that while inflation differentials in the U.S. are short-term and a sign of adjustment, the differentials of inflation in the Euro area had a structural pattern and are connected with different reactions of

\footnotetext{
${ }^{47}$ As a proxy for Balassa-Samuelson effect. Values only for manufacturing industry seems to be too narrow definition. Problems with data capturing productivity growth are discussed in Égert (2007).

${ }^{48}$ Results for Eurostat quarterly data are available from authors on request.
} 
individual Euro area economies to common shocks.

For the panel regressions we used two annual and one quarterly databases and three to five different specifications for the Euro area. The general model includes as independent variables proxies for the output gap, price level convergence, fiscal position and nominal effective exchange rate. It additionally presents time dummies that capture Euro area aggregates, so the regressions should therefore explain inflation differentials across Euro area countries as idiosyncratic national movements.

The overall results from the GMM estimations point to the relevance of cyclical factors and to a lesser extent real convergence factors (output gaps and price level convergence respectively). Coefficients for the output gap were somewhat smaller than in previous studies (lying between 0.005 and 0.013 ). For price level convergence the coefficients lie between -0.02 and -0.05 . For example, a coefficient of -0.05 implies that a country with a price level $20 \%$ below the Euro area average is likely to experience inflation $1 \%$ above the area average. Almost no support is found for the nominal effective exchange rate, a result that can be explained by the extension of the time span used for the analysis and allows us to state that after almost ten years of common currency, exchange rate movements have a diminished impact on inflation differentials, which in turn implies that the policy concern of minimizing the impact of real exchange rate overshooting becomes a second order concern.

The present analysis can be extended to include additional variables that may play a role in explaining differentials like for example productivity levels (accounting for the so-called Balassa-Samuelson effect) or oil prices. The other possibility seems to be a structural model for the Euro area. More importantly, it could be complemented with an up-to-date stylized New Keynesian model. The current financial crisis is shaking the foundations both of the economies all across the globe and of modern economic theory. In the wake of these events, and although the outcome is unpredictable, traditional (national) influences which have been important for a currency union have been superseded by external (global) influences that can be expected to play a more important role in the future. Therefore the role of external factors affecting inflation rates can be expected to rise, with national ones playing a relatively minor role. On the other hand, the impact of the fiscal measures taken so far (and the ones probably yet to be taken) is difficult to estimate but will most likely play a role in the path of inflation, especially after the differentiation that markets are already making of the previously homogeneous European countries. The same does hold true for repercussions of increased money supply by central banks all over the world. These unprecedented levels have not been seen for years. However, finding the exact timing to undo the current excessive money growth is extremely difficult and the impact of the current measures therefore depends on developments of many factors that are beyond the scope of monetary authorities' instruments. 


\section{Appendix}

\section{Tables - OLS estimations}

Table 1A: Inflation differentials in Euro area. OLS estimates for OECD data 1999-2007

\begin{tabular}{|l|c|c|c|c|c|c|c|}
\hline & $(1)$ & $(2)$ & $(3)$ & $(4)$ & $(5)$ & $(6)$ & $(7)$ \\
\hline EA10 & & & & & & & \\
OG_ & 0.000114 & 0.000486 & $-9.00 \mathrm{e}-05$ & -0.148 & -0.00629 & -0.00608 & -0.00558 \\
& $(0.003)$ & $(0.003)$ & $(0.003)$ & $(0.094)$ & $(0.007)$ & $(0.008)$ & $(0.006)$ \\
DNEER_1 & 0.000683 & $4.96 \mathrm{e}-05$ & 0.000156 & 0.0105 & 0.00200 & 0.00195 & 0.00197 \\
& $(0.001)$ & $(0.001)$ & $(0.001)$ & $(0.026)$ & $(0.002)$ & $(0.002)$ & $(0.002)$ \\
GPB & $3.34 \mathrm{e}-08$ & $3.51 \mathrm{e}-08$ & $1.67 \mathrm{e}-08$ & $6.34 \mathrm{e}-06^{*}$ & $3.74 \mathrm{e}-07$ & $3.38 \mathrm{e}-07$ & $2.63 \mathrm{e}-07$ \\
& $(0.000)$ & $(0.000)$ & $(0.000)$ & $(0.000)$ & $(0.000)$ & $(0.000)$ & $(0.000)$ \\
PPP_1 & $-0.0393 * * *$ & $-0.0424^{* * *}$ & $-0.0400^{* * *}$ & $1.042^{*}$ & -0.00583 & 0.00776 & 0.000596 \\
& $(0.013)$ & $(0.012)$ & $(0.013)$ & $(0.601)$ & $(0.040)$ & $(0.032)$ & $(0.030)$ \\
Adjusted $R^{2}$ & 0.946 & 0.923 & 0.915 & 0.053 & 0.721 & 0.777 & 0.804 \\
\hline EA11 & & & & & & & \\
\hline OG & 0.000367 & 0.000625 & 0.000322 & -0.0655 & -0.00624 & -0.00613 & -0.00603 \\
& $(0.003)$ & $(0.003)$ & $(0.003)$ & $(0.060)$ & $(0.007)$ & $(0.007)$ & $(0.006)$ \\
DNEER_1 & 0.000301 & -0.000335 & -0.000302 & 0.00453 & 0.00119 & 0.000847 & 0.000945 \\
& $(0.001)$ & $(0.001)$ & $(0.001)$ & $(0.018)$ & $(0.002)$ & $(0.002)$ & $(0.002)$ \\
GPB & $6.90 \mathrm{e}-08$ & $7.00 \mathrm{e}-08$ & $5.39 \mathrm{e}-08$ & $5.70 \mathrm{e}-06$ & $3.95 \mathrm{e}-07$ & $3.35 \mathrm{e}-07$ & $2.72 \mathrm{e}-07$ \\
& $(0.000)$ & $(0.000)$ & $(0.000)$ & $(0.000)$ & $(0.000)$ & $(0.000)$ & $(0.000)$ \\
PPP_1 & -0.0235 & -0.0254 & -0.0220 & $1.038^{*}$ & 0.0287 & 0.0502 & 0.0358 \\
& $(0.019)$ & $(0.020)$ & $(0.022)$ & $(0.563)$ & $(0.052)$ & $(0.051)$ & $(0.044)$ \\
Adjusted $R^{2}$ & 0.939 & 0.915 & 0.903 & -0.054 & 0.707 & 0.767 & 0.777 \\
\hline EA12 & & & & & & & \\
\hline OOG & 0.000124 & 0.000375 & $6.07 \mathrm{e}-05$ & -0.00611 & -0.00680 & -0.00571 & -0.00560 \\
& $(0.003)$ & $(0.003)$ & $(0.003)$ & $(0.081)$ & $(0.007)$ & $(0.007)$ & $(0.006)$ \\
DNEER_1 & $-2.33 \mathrm{e}-05$ & -0.000545 & -0.000473 & -0.000841 & 0.00125 & 0.00108 & 0.000901 \\
& $(0.001)$ & $(0.001)$ & $(0.001)$ & $(0.018)$ & $(0.002)$ & $(0.001)$ & $(0.001)$ \\
GPB & $5.47 \mathrm{e}-08$ & $5.94 \mathrm{e}-08$ & $4.41 \mathrm{e}-08$ & $8.98 \mathrm{e}-066^{*}$ & $3.80 \mathrm{e}-07$ & $3.55 \mathrm{e}-07$ & $2.81 \mathrm{e}-07$ \\
& $(0.000)$ & $(0.000)$ & $(0.000)$ & $(0.000)$ & $(0.000)$ & $(0.000)$ & $(0.000)$ \\
PPP_1 & -0.0192 & -0.0205 & -0.0177 & $1.323^{* *}$ & 0.0264 & 0.0459 & 0.0340 \\
& $(0.018)$ & $(0.018)$ & $(0.021)$ & $(0.594)$ & $(0.049)$ & $(0.049)$ & $(0.042)$ \\
Adjusted $R^{2}$ & 0.944 & 0.924 & 0.913 & -0.060 & 0.730 & 0.779 & 0.794 \\
\hline
\end{tabular}

Notes: Models (1), (2), (3), (4), (5), (6) and (7) include as dependent variable the growth rate in HICP, HICP less Energy, HICP less Energy and Unprocessed Foods, Wages, GDP Deflator, Total Domestic Expenditure Deflator and Private Final Consumption Expenditure Deflator respectively. OG, DNEER 1, GPB and PPP 1 account for Output Gap, lagged differenced Nominal Effective Exchange Rate, Cyclically Adjusted Government Primary Balance and lagged Price Level Indicator based on PPP respectively. $* * *, * *$ and * denote significance at 1, 5 and $10 \%$ levels respectively. Time dummies included. Robust standard errors in parentheses. All computations done using commands for StataSE 10.0. 


\section{Tables - GMM estimations}

Table 2A: Inflation differentials in Euro area. GMM estimates for OECD data 1999-2007

\begin{tabular}{|c|c|c|c|c|c|c|c|}
\hline & (1) & (2) & (3) & (4) & (5) & (6) & (7) \\
\hline \multicolumn{8}{|l|}{ EA10 } \\
\hline $\mathrm{OG}$ & $\begin{array}{c}0.00659 * * * \\
(0.002)\end{array}$ & $\begin{array}{c}0.00636^{* * *} \\
(0.002)\end{array}$ & $\begin{array}{c}0.00750 * * * \\
(0.002)\end{array}$ & $\begin{array}{l}-0.0151 \\
(0.083)\end{array}$ & $\begin{array}{c}0.00936^{*} \\
(0.006)\end{array}$ & $\begin{array}{c}0.0108 * * \\
(0.005)\end{array}$ & $\begin{array}{c}0.00755^{*} \\
(0.004)\end{array}$ \\
\hline GPB & $\begin{array}{c}-1.21 \mathrm{e}-07 \\
(0.000)\end{array}$ & $\begin{array}{c}-1.69 \mathrm{e}-07 \\
(0.000)\end{array}$ & $\begin{array}{c}-1.10 \mathrm{e}-07 \\
(0.000)\end{array}$ & $\begin{array}{c}-8.41 \mathrm{e}-06 \\
(0.000)\end{array}$ & $\begin{array}{c}3.06 \mathrm{e}-07 \\
(0.000)\end{array}$ & $\begin{array}{c}6.65 \mathrm{e}-07 \\
(0.000)\end{array}$ & $\begin{array}{c}2.55 \mathrm{e}-07 \\
(0.000)\end{array}$ \\
\hline DNEER_1 & $\begin{array}{c}0.000482 \\
(0.001)\end{array}$ & $\begin{array}{c}-0.000184 \\
(0.001)\end{array}$ & $\begin{array}{c}-3.52 \mathrm{e}-05 \\
(0.001)\end{array}$ & $\begin{array}{c}-0.00304 \\
(0.018)\end{array}$ & $\begin{array}{c}0.00176 \\
(0.001)\end{array}$ & $\begin{array}{c}0.00203 * \\
(0.001)\end{array}$ & $\begin{array}{c}0.00181 * \\
(0.001)\end{array}$ \\
\hline PPP_1 & $\begin{array}{c}-0.0483 * * * \\
(0.012)\end{array}$ & $\begin{array}{c}-0.0512 * * * \\
(0.012)\end{array}$ & $\begin{array}{c}-0.0500 * * * \\
(0.013)\end{array}$ & $\begin{array}{c}0.744 \\
(0.509)\end{array}$ & $\begin{array}{l}-0.0245 \\
(0.034)\end{array}$ & $\begin{array}{c}-0.00844 \\
(0.028)\end{array}$ & $\begin{array}{l}-0.0146 \\
(0.025)\end{array}$ \\
\hline Adjusted $R^{2}$ & 0.942 & 0.920 & 0.908 & . & 0.712 & 0.764 & 0.797 \\
\hline \multicolumn{8}{|l|}{ EA11 } \\
\hline $\mathrm{OG}$ & $\begin{array}{c}0.00465 * * * \\
(0.001)\end{array}$ & $\begin{array}{c}0.00445 * * * \\
(0.001)\end{array}$ & $\begin{array}{c}0.00547 * * * \\
(0.002)\end{array}$ & $\begin{array}{l}-0.0500 \\
(0.082)\end{array}$ & $\begin{array}{c}0.00510 \\
(0.003)\end{array}$ & $\begin{array}{c}0.00521 * \\
(0.003)\end{array}$ & $\begin{array}{l}0.00415 \\
(0.003)\end{array}$ \\
\hline GPB & $\begin{array}{c}-7.82 \mathrm{e}-08 \\
(0.000)\end{array}$ & $\begin{array}{c}-1.14 \mathrm{e}-07 \\
(0.000)\end{array}$ & $\begin{array}{c}-7.17 \mathrm{e}-08 \\
(0.000)\end{array}$ & $\begin{array}{c}-1.59 \mathrm{e}-05 \\
(0.000)\end{array}$ & $\begin{array}{c}1.73 e-07 \\
(0.000)\end{array}$ & $\begin{array}{c}3.88 \mathrm{e}-07 \\
(0.000)\end{array}$ & $\begin{array}{c}9.46 \mathrm{e}-08 \\
(0.000)\end{array}$ \\
\hline DNEER_1 & $\begin{array}{c}0.000119 \\
(0.001)\end{array}$ & $\begin{array}{c}-0.000561 \\
(0.001)\end{array}$ & $\begin{array}{c}-0.000458 \\
(0.001)\end{array}$ & $\begin{array}{l}-0.0135 \\
(0.021)\end{array}$ & $\begin{array}{c}0.000915 \\
(0.001)\end{array}$ & $\begin{array}{c}0.000904 \\
(0.001)\end{array}$ & $\begin{array}{c}0.000723 \\
(0.001)\end{array}$ \\
\hline PPP_1 & $\begin{array}{r}-0.0227 \\
(0.019)\end{array}$ & $\begin{array}{r}-0.0243 \\
(0.020)\end{array}$ & $\begin{array}{l}-0.0213 \\
(0.022)\end{array}$ & $\begin{array}{c}0.817 \\
(0.595)\end{array}$ & $\begin{array}{l}0.0298 \\
(0.052)\end{array}$ & $\begin{array}{l}0.0497 \\
(0.050)\end{array}$ & $\begin{array}{l}0.0367 \\
(0.044)\end{array}$ \\
\hline Adjusted $R^{2}$ & 0.941 & 0.919 & 0.906 & . & 0.714 & 0.773 & 0.780 \\
\hline \multicolumn{8}{|l|}{ EA12 } \\
\hline $\mathrm{OG}$ & $\begin{array}{c}0.00504 * * * \\
(0.002)\end{array}$ & $\begin{array}{c}0.00477 * * * \\
(0.002)\end{array}$ & $\begin{array}{c}0.00586 * * * \\
(0.002)\end{array}$ & $\begin{array}{c}-0.0793 \\
(0.138)\end{array}$ & $\begin{array}{c}0.00591 \\
(0.004)\end{array}$ & $\begin{array}{c}0.00499 \\
(0.003)\end{array}$ & $\begin{array}{c}0.00413 \\
(0.003)\end{array}$ \\
\hline GPB & $\begin{array}{c}-6.49 \mathrm{e}-08 \\
(0.000)\end{array}$ & $\begin{array}{c}-1.46 \mathrm{e}-07 \\
(0.000)\end{array}$ & $\begin{array}{c}-8.63 e-08 \\
(0.000)\end{array}$ & $\begin{array}{c}-2.64 \mathrm{e}-05^{*} \\
(0.000)\end{array}$ & $\begin{array}{c}4.11 \mathrm{e}-07 \\
(0.000)\end{array}$ & $\begin{array}{c}4.42 \mathrm{e}-07 \\
(0.000)\end{array}$ & $\begin{array}{c}1.52 \mathrm{e}-07 \\
(0.000)\end{array}$ \\
\hline DNEER_1 & $\begin{array}{c}-0.000178 \\
(0.001)\end{array}$ & $\begin{array}{c}-0.000776 \\
(0.001)\end{array}$ & $\begin{array}{c}-0.000646 \\
(0.001)\end{array}$ & $\begin{array}{l}-0.0213 \\
(0.030)\end{array}$ & $\begin{array}{c}0.00117 \\
(0.001)\end{array}$ & $\begin{array}{c}0.00106 \\
(0.001)\end{array}$ & $\begin{array}{c}0.000695 \\
(0.001)\end{array}$ \\
\hline PPP_1 & $\begin{array}{r}-0.0196 \\
(0.019)\end{array}$ & $\begin{array}{r}-0.0209 \\
(0.019)\end{array}$ & $\begin{array}{l}-0.0183 \\
(0.022)\end{array}$ & $\begin{array}{c}0.852 \\
(0.690)\end{array}$ & $\begin{array}{c}0.0251 \\
(0.050)\end{array}$ & $\begin{array}{c}0.0449 \\
(0.050)\end{array}$ & $\begin{array}{c}0.0330 \\
(0.043)\end{array}$ \\
\hline Adjusted $R^{2}$ & 0.944 & 0.924 & 0.912 & . & 0.730 & 0.784 & 0.796 \\
\hline
\end{tabular}

Notes: Models (1), (2), (3), (4), (5), (6) and (7) include as dependent variable the growth rate in HICP, HICP less Energy, HICP less Energy and Unprocessed Foods, Wages, GDP Deflator, Total Domestic Expenditure Deflator and Private Final Consumption Expenditure Deflator respectively. OG, DNEER 1, GPB CA and PPP 1 account for Output Gap, lagged differenced Nominal Effective Exchange Rate, Cyclically Adjusted Government Primary Balance and lagged Price Level Indicator based on PPP respectively. Output Gap (OG) and Cyclically Adjusted Government Primary Balance (GPB) are instrumented by their lagged values. $* * * * *$ and $*$ denote significance at 1,5 and $10 \%$ levels respectively. Time dummies included. Robust standard errors in parentheses. All computations done using commands for StataSE 10.0. 
Table 3A: Inflation differentials in Euro area. GMM estimates for Eurostat annual data 1999-2007

\begin{tabular}{|c|c|c|c|c|c|c|}
\hline & $(1)$ & $(2)$ & (3) & (4) & $(5)$ & $(6)$ \\
\hline \multicolumn{7}{|l|}{ EA10 } \\
\hline $\mathrm{OG}$ & $\begin{array}{c}0.00902 * * * \\
(0.001)\end{array}$ & $\begin{array}{c}0.00974 * * * \\
(0.001)\end{array}$ & $\begin{array}{c}0.0102 * * * \\
(0.001)\end{array}$ & $\begin{array}{c}0.0103 * * * \\
(0.004)\end{array}$ & $\begin{array}{c}0.0136 * * * \\
(0.003)\end{array}$ & $\begin{array}{c}0.0136 * * * \\
(0.003)\end{array}$ \\
\hline GGD & $\begin{array}{c}1.51 \mathrm{e}-07 \\
(0.000)\end{array}$ & $\begin{array}{c}1.37 \mathrm{e}-07 \\
(0.000)\end{array}$ & $\begin{array}{c}1.56 \mathrm{e}-07 \\
(0.000)\end{array}$ & $\begin{array}{c}1.19 \mathrm{e}-07 \\
(0.000)\end{array}$ & $\begin{array}{c}7.48 \mathrm{e}-08 \\
(0.000)\end{array}$ & $\begin{array}{c}7.48 \mathrm{e}-08 \\
(0.000)\end{array}$ \\
\hline DNEER_1 & $\begin{array}{c}-0.000745 \\
(0.001)\end{array}$ & $\begin{array}{c}-0.00121 \\
(0.001)\end{array}$ & $\begin{array}{c}-0.00118 \\
(0.001)\end{array}$ & $\begin{array}{c}-0.00305 \\
(0.002)\end{array}$ & $\begin{array}{c}-0.00269 * * \\
(0.001)\end{array}$ & $\begin{array}{c}-0.00269^{* *} \\
(0.001)\end{array}$ \\
\hline CPL_HFCE1 & $\begin{array}{c}-0.0337 * * * \\
(0.010)\end{array}$ & $\begin{array}{c}-0.0394 * * * \\
(0.009)\end{array}$ & $\begin{array}{c}-0.0370 * * * \\
(0.010)\end{array}$ & $\begin{array}{c}-0.00864 \\
(0.018)\end{array}$ & $\begin{array}{r}-0.0281 \\
(0.027)\end{array}$ & $\begin{array}{r}-0.0281 \\
(0.027)\end{array}$ \\
\hline Adjusted $R^{2}$ & 0.931 & 0.905 & 0.890 & 0.917 & 0.843 & 0.843 \\
\hline \multicolumn{7}{|l|}{ EA11 } \\
\hline $\mathrm{OG}$ & $\begin{array}{c}0.00674 * * * \\
(0.002)\end{array}$ & $\begin{array}{c}0.00716^{* * * *} \\
(0.002)\end{array}$ & $\begin{array}{c}0.00792 * * * \\
(0.002)\end{array}$ & $\begin{array}{c}0.00781 * \\
(0.004)\end{array}$ & $\begin{array}{c}0.0106^{* * *} \\
(0.003)\end{array}$ & $\begin{array}{c}0.0107 * * * \\
(0.003)\end{array}$ \\
\hline GGD & $\begin{array}{c}8.38 \mathrm{e}-08 \\
(0.000)\end{array}$ & $\begin{array}{c}6.57 \mathrm{e}-08 \\
(0.000)\end{array}$ & $\begin{array}{c}7.29 \mathrm{e}-08 \\
(0.000)\end{array}$ & $\begin{array}{c}1.14 \mathrm{e}-07 \\
(0.000)\end{array}$ & $\begin{array}{c}5.93 \mathrm{e}-08 \\
(0.000)\end{array}$ & $\begin{array}{c}5.53 \mathrm{e}-08 \\
(0.000)\end{array}$ \\
\hline DNEER_1 & $\begin{array}{c}-0.000403 \\
(0.001)\end{array}$ & $\begin{array}{c}-0.000825 \\
(0.001)\end{array}$ & $\begin{array}{c}-0.000817 \\
(0.001)\end{array}$ & $\begin{array}{c}-0.00203 \\
(0.003)\end{array}$ & $\begin{array}{c}-0.00217 \\
(0.001)\end{array}$ & $\begin{array}{c}-0.00226 \\
(0.001)\end{array}$ \\
\hline CPL_HFCE1 & $\begin{array}{c}-0.00864 \\
(0.018)\end{array}$ & $\begin{array}{r}-0.0121 \\
(0.019)\end{array}$ & $\begin{array}{c}-0.00843 \\
(0.021)\end{array}$ & $\begin{array}{l}0.0173 \\
(0.032)\end{array}$ & $\begin{array}{c}0.000858 \\
(0.027)\end{array}$ & $\begin{array}{c}-0.000815 \\
(0.026)\end{array}$ \\
\hline Adjusted $R^{2}$ & 0.926 & 0.898 & 0.881 & 0.882 & 0.837 & 0.841 \\
\hline \multicolumn{7}{|l|}{ EA12 } \\
\hline $\mathrm{OG}$ & $\begin{array}{c}0.00605 * * * \\
(0.002)\end{array}$ & $\begin{array}{c}0.00714 * * * \\
(0.002)\end{array}$ & $\begin{array}{c}0.00785 * * * \\
(0.002)\end{array}$ & $\begin{array}{c}0.00750 * \\
(0.004)\end{array}$ & $\begin{array}{c}0.00827 * * \\
(0.003)\end{array}$ & $\begin{array}{c}0.00839 * * \\
(0.003)\end{array}$ \\
\hline GGD & $\begin{array}{c}1.02 \mathrm{e}-07 * \\
(0.000)\end{array}$ & $\begin{array}{c}8.34 \mathrm{e}-08 \\
(0.000)\end{array}$ & $\begin{array}{c}8.64 \mathrm{e}-08 \\
(0.000)\end{array}$ & $\begin{array}{c}9.94 \mathrm{e}-08 \\
(0.000)\end{array}$ & $\begin{array}{c}8.15 \mathrm{e}-08 \\
(0.000)\end{array}$ & $\begin{array}{l}7.78 \mathrm{e}-08 \\
(0.000)\end{array}$ \\
\hline DNEER_1 & $\begin{array}{c}-0.000853 \\
(0.001)\end{array}$ & $\begin{array}{c}-0.00117 \\
(0.001)\end{array}$ & $\begin{array}{c}-0.00106 \\
(0.001)\end{array}$ & $\begin{array}{c}-0.00150 \\
(0.002)\end{array}$ & $\begin{array}{c}-0.000837 \\
(0.002)\end{array}$ & $\begin{array}{c}-0.000919 \\
(0.002)\end{array}$ \\
\hline CPL_HFCE1 & $\begin{array}{c}-0.00903 \\
(0.017)\end{array}$ & $\begin{array}{c}-0.0116 \\
(0.018)\end{array}$ & $\begin{array}{c}-0.00849 \\
(0.020)\end{array}$ & $\begin{array}{l}0.0140 \\
(0.032)\end{array}$ & $\begin{array}{c}-0.00351 \\
(0.026)\end{array}$ & $\begin{array}{c}-0.00519 \\
(0.025)\end{array}$ \\
\hline Adjusted $R^{2}$ & 0.934 & 0.909 & 0.894 & 0.891 & 0.849 & 0.852 \\
\hline \multicolumn{7}{|l|}{ EA13 } \\
\hline $\mathrm{OG}$ & $\begin{array}{c}0.00844 * * \\
(0.004)\end{array}$ & $\begin{array}{c}0.00638 * * * \\
(0.002)\end{array}$ & $\begin{array}{c}0.00702 * * * \\
(0.002)\end{array}$ & $\begin{array}{l}0.00659 \\
(0.005)\end{array}$ & $\begin{array}{c}0.00832 * * \\
(0.003)\end{array}$ & $\begin{array}{c}0.00868 * * * \\
(0.003)\end{array}$ \\
\hline GGD & $\begin{array}{c}1.20 \mathrm{e}-07^{*} \\
(0.000)\end{array}$ & $\begin{array}{c}6.86 \mathrm{e}-08 \\
(0.000)\end{array}$ & $\begin{array}{c}7.10 \mathrm{e}-08 \\
(0.000)\end{array}$ & $\begin{array}{c}1.41 \mathrm{e}-07 \\
(0.000)\end{array}$ & $\begin{array}{c}8.85 \mathrm{e}-08 \\
(0.000)\end{array}$ & $\begin{array}{c}7.23 \mathrm{e}-08 \\
(0.000)\end{array}$ \\
\hline DNEER_1 & $\begin{array}{c}-0.00257 \\
(0.002)\end{array}$ & $\begin{array}{c}-0.00421 * * * \\
(0.001)\end{array}$ & $\begin{array}{c}-0.00463 * * * \\
(0.001)\end{array}$ & $\begin{array}{c}-0.00270 \\
(0.003)\end{array}$ & $\begin{array}{c}-0.00280 \\
(0.002)\end{array}$ & $\begin{array}{c}-0.00127 \\
(0.001)\end{array}$ \\
\hline CPL_HFCE1 & $\begin{array}{c}-0.0159 \\
(0.027)\end{array}$ & $\begin{array}{r}-0.0221 \\
(0.015)\end{array}$ & $\begin{array}{r}-0.0201 \\
(0.017)\end{array}$ & $\begin{array}{r}-0.0261 \\
(0.029)\end{array}$ & $\begin{array}{c}-0.0218 \\
(0.023)\end{array}$ & $\begin{array}{c}-0.00437 \\
(0.017)\end{array}$ \\
\hline Adjusted $R^{2}$ & 0.858 & 0.906 & 0.891 & 0.887 & 0.845 & 0.865 \\
\hline
\end{tabular}


Table 3A: Inflation differentials in Euro area. GMM estimates for Eurostat annual data 1999-2007 (cont.)

\begin{tabular}{|l|c|c|c|c|c|c|}
\hline & $(1)$ & $(2)$ & $(3)$ & $(4)$ & $(5)$ & $(6)$ \\
\hline EA15 & & & & & & \\
\hline OG & $0.00572^{*}$ & $0.00432^{* *}$ & $0.00501 * *$ & 0.00623 & $0.00747^{* *}$ & $0.00756^{* * *}$ \\
& $(0.003)$ & $(0.002)$ & $(0.002)$ & $(0.004)$ & $(0.003)$ & $(0.003)$ \\
GGD & $1.40 \mathrm{e}-07 * *$ & $7.91 \mathrm{e}-08$ & $7.66 \mathrm{e}-08$ & $1.83 \mathrm{e}-07 *$ & $1.22 \mathrm{e}-07$ & $9.94 \mathrm{e}-08$ \\
& $(0.000)$ & $(0.000)$ & $(0.000)$ & $(0.000)$ & $(0.000)$ & $(0.000)$ \\
DNEER_1 & -0.00217 & $-0.00376^{* * *}$ & $-0.00437 * *$ & -0.00113 & -0.00218 & -0.000238 \\
& $(0.002)$ & $(0.001)$ & $(0.001)$ & $(0.003)$ & $(0.002)$ & $(0.001)$ \\
CPL_HFCE1 & -0.0194 & $-0.0262^{* *}$ & $-0.0248^{* *}$ & -0.0244 & -0.0218 & -0.0105 \\
& $(0.015)$ & $(0.011)$ & $(0.012)$ & $(0.019)$ & $(0.017)$ & $(0.014)$ \\
Adjusted $R^{2}$ & 0.882 & 0.921 & 0.902 & 0.901 & 0.870 & 0.885 \\
\hline
\end{tabular}

Notes: Models (1), (2), (3), (4), (5) and (6) include as dependent variable the growth rate in HICP, HICP less Energy, HICP less Energy and Unprocessed Foods, Labour Cost Index, GDP Deflator based on national currencies, and GDP Deflator based on Euro respectively. OG, DNEER_1, GGD and CPL_HFCE1 account for Output Gap, lagged differenced Nominal Effective Exchange Rate, Government General Deficit and lagged Comparative Price Level (Household Final Consumption Expenditure)respectively. Output Gap (OG) and Government General Deficit (GGD) are instrumented by their lagged values. ${ }^{* * *},{ }^{* *}$ and ${ }^{*}$ denote significance at the 1,5 and $10 \%$ levels respectively. Time dummies included. Robust standard errors in parentheses. All computations done using commands for StataSE 10.0. 
Table 4A: Inflation differentials in Euro area. GMM estimates for Eurostat quarterly data 1999-2007 (1 lag)

\begin{tabular}{|c|c|c|c|c|c|c|}
\hline & (1) & (2) & (3) & (4) & $(5)$ & (6) \\
\hline \multicolumn{7}{|l|}{ EA10 } \\
\hline $\mathrm{OG}$ & $\begin{array}{c}0.00406 \\
(0.007)\end{array}$ & $\begin{array}{c}0.00343 \\
(0.008)\end{array}$ & $\begin{array}{c}0.00434 \\
(0.008)\end{array}$ & $\begin{array}{c}0.0286^{* *} \\
(0.013)\end{array}$ & $\begin{array}{l}0.00757 \\
(0.009)\end{array}$ & $\begin{array}{c}0.00757 \\
(0.009)\end{array}$ \\
\hline GGD & $\begin{array}{c}5.75 \mathrm{e}-08^{*} \\
(0.000)\end{array}$ & $\begin{array}{c}6.10 \mathrm{e}-08 * \\
(0.000)\end{array}$ & $\begin{array}{c}6.21 \mathrm{e}-08 \\
(0.000)\end{array}$ & $\begin{array}{c}2.66 \mathrm{e}-07 * * * \\
(0.000)\end{array}$ & $\begin{array}{c}5.32 \mathrm{e}-08 \\
(0.000)\end{array}$ & $\begin{array}{c}5.32 \mathrm{e}-08 \\
(0.000)\end{array}$ \\
\hline DNEER_1 & $\begin{array}{c}0.000472 \\
(0.001)\end{array}$ & $\begin{array}{c}0.000754 \\
(0.001)\end{array}$ & $\begin{array}{c}0.000360 \\
(0.001)\end{array}$ & $\begin{array}{c}0.00394 \\
(0.002)\end{array}$ & $\begin{array}{c}-0.000124 \\
(0.002)\end{array}$ & $\begin{array}{c}-0.000124 \\
(0.002)\end{array}$ \\
\hline CPL_HFCE1 & $\begin{array}{c}-0.00467 \\
(0.008)\end{array}$ & $\begin{array}{c}-0.00759 \\
(0.008)\end{array}$ & $\begin{array}{c}-0.00522 \\
(0.008)\end{array}$ & $\begin{array}{c}-0.00462 \\
(0.015)\end{array}$ & $\begin{array}{c}-0.0402 * * * \\
(0.013)\end{array}$ & $\begin{array}{c}-0.0402 * * * \\
(0.013)\end{array}$ \\
\hline Adjusted $R^{2}$ & 0.943 & 0.919 & 0.910 & 0.894 & 0.869 & 0.869 \\
\hline \multicolumn{7}{|l|}{ EA11 } \\
\hline $\mathrm{OG}$ & $\begin{array}{c}0.00480 \\
(0.007)\end{array}$ & $\begin{array}{c}0.00441 \\
(0.007)\end{array}$ & $\begin{array}{c}0.00584 \\
(0.008)\end{array}$ & $\begin{array}{c}0.0306 * * \\
(0.014)\end{array}$ & $\begin{array}{c}0.00829 \\
(0.008)\end{array}$ & $\begin{array}{c}0.00816 \\
(0.008)\end{array}$ \\
\hline GGD & $\begin{array}{c}4.50 \mathrm{e}-08^{*} \\
(0.000)\end{array}$ & $\begin{array}{c}4.79 \mathrm{e}-08 * \\
(0.000)\end{array}$ & $\begin{array}{c}4.63 \mathrm{e}-08 \\
(0.000)\end{array}$ & $\begin{array}{c}2.45 \mathrm{e}-07 * * * \\
(0.000)\end{array}$ & $\begin{array}{c}3.95 \mathrm{e}-08 \\
(0.000)\end{array}$ & $\begin{array}{l}4.05 \mathrm{e}-08 \\
(0.000)\end{array}$ \\
\hline DNEER_1 & $\begin{array}{c}0.00191 \\
(0.001)\end{array}$ & $\begin{array}{c}0.00225^{*} \\
(0.001)\end{array}$ & $\begin{array}{l}0.00195 \\
(0.001)\end{array}$ & $\begin{array}{c}0.00587 * * \\
(0.003)\end{array}$ & $\begin{array}{c}0.000966 \\
(0.002)\end{array}$ & $\begin{array}{c}0.000821 \\
(0.002)\end{array}$ \\
\hline CPL_HFCE1 & $\begin{array}{c}-0.00980 \\
(0.007)\end{array}$ & $\begin{array}{c}-0.0123 \\
(0.008)\end{array}$ & $\begin{array}{l}-0.0109 \\
(0.008)\end{array}$ & $\begin{array}{c}-0.00834 \\
(0.017)\end{array}$ & $\begin{array}{c}-0.0383 * * * \\
(0.012)\end{array}$ & $\begin{array}{c}-0.0383 * * * \\
(0.012)\end{array}$ \\
\hline Adjusted $R^{2}$ & 0.934 & 0.908 & 0.895 & 0.861 & 0.860 & 0.863 \\
\hline \multicolumn{7}{|l|}{ EA12 } \\
\hline $\mathrm{OG}$ & $\begin{array}{c}0.000440 \\
(0.005)\end{array}$ & $\begin{array}{c}0.000402 \\
(0.005)\end{array}$ & $\begin{array}{c}0.00150 \\
(0.006)\end{array}$ & $\begin{array}{c}0.0231 * \\
(0.012)\end{array}$ & $\begin{array}{c}0.00130 \\
(0.007)\end{array}$ & $\begin{array}{c}0.00114 \\
(0.007)\end{array}$ \\
\hline GGD & $\begin{array}{c}5.06 \mathrm{e}-08 * * \\
(0.000)\end{array}$ & $\begin{array}{c}5.63 \mathrm{e}-08 * * \\
(0.000)\end{array}$ & $\begin{array}{c}5.31 \mathrm{e}-08^{*} \\
(0.000)\end{array}$ & $\begin{array}{c}2.39 \mathrm{e}-07 * * * \\
(0.000)\end{array}$ & $\begin{array}{c}5.28 \mathrm{e}-08 \\
(0.000)\end{array}$ & $\begin{array}{c}5.35 \mathrm{e}-08 \\
(0.000)\end{array}$ \\
\hline DNEER_1 & $\begin{array}{c}0.00160 \\
(0.001)\end{array}$ & $\begin{array}{c}0.00225^{*} \\
(0.001)\end{array}$ & $\begin{array}{c}0.00188 \\
(0.001)\end{array}$ & $\begin{array}{c}0.00481 * \\
(0.003)\end{array}$ & $\begin{array}{c}-0.000699 \\
(0.002)\end{array}$ & $\begin{array}{c}-0.000847 \\
(0.002)\end{array}$ \\
\hline CPL_HFCE1 & $\begin{array}{c}-0.00961 \\
(0.007)\end{array}$ & $\begin{array}{c}-0.0119 * \\
(0.007)\end{array}$ & $\begin{array}{c}-0.0108 \\
(0.007)\end{array}$ & $\begin{array}{r}-0.0101 \\
(0.016)\end{array}$ & $\begin{array}{c}-0.0370 * * * \\
(0.011)\end{array}$ & $\begin{array}{c}-0.0371 * * * \\
(0.011)\end{array}$ \\
\hline Adjusted $R^{2}$ & 0.940 & 0.919 & 0.908 & 0.875 & 0.867 & 0.870 \\
\hline \multicolumn{7}{|l|}{ EA13 } \\
\hline $\mathrm{OG}$ & $\begin{array}{c}-0.00379 \\
(0.010)\end{array}$ & $\begin{array}{c}0.00219 \\
(0.005)\end{array}$ & $\begin{array}{c}0.00309 \\
(0.006)\end{array}$ & $\begin{array}{c}0.0171 \\
(0.012)\end{array}$ & $\begin{array}{c}0.000319 \\
(0.008)\end{array}$ & $\begin{array}{c}0.00206 \\
(0.007)\end{array}$ \\
\hline GGD & $\begin{array}{c}1.35 \mathrm{e}-08 \\
(0.000)\end{array}$ & $\begin{array}{c}4.69 \mathrm{e}-08 * \\
(0.000)\end{array}$ & $\begin{array}{c}4.46 \mathrm{e}-08 \\
(0.000)\end{array}$ & $\begin{array}{c}2.09 \mathrm{e}-07 * * * \\
(0.000)\end{array}$ & $\begin{array}{c}2.35 \mathrm{e}-08 \\
(0.000)\end{array}$ & $\begin{array}{c}3.93 \mathrm{e}-08 \\
(0.000)\end{array}$ \\
\hline DNEER_1 & $\begin{array}{c}-0.00605 * * * \\
(0.002)\end{array}$ & $\begin{array}{c}-0.00187^{* *} \\
(0.001)\end{array}$ & $\begin{array}{c}-0.00229 * * \\
(0.001)\end{array}$ & $\begin{array}{c}-0.00325^{*} \\
(0.002)\end{array}$ & $\begin{array}{c}-0.00474 * * * \\
(0.001)\end{array}$ & $\begin{array}{c}-0.000459 \\
(0.001)\end{array}$ \\
\hline CPL_HFCE1 & $\begin{array}{c}0.00737 \\
(0.017)\end{array}$ & $\begin{array}{c}-0.0235^{* * *} \\
(0.006)\end{array}$ & $\begin{array}{c}-0.0226 * * * \\
(0.007)\end{array}$ & $\begin{array}{c}-0.0319 * * \\
(0.014)\end{array}$ & $\begin{array}{c}-0.0270^{* *} \\
(0.011)\end{array}$ & $\begin{array}{c}-0.0173^{*} \\
(0.009)\end{array}$ \\
\hline Adjusted $R^{2}$ & 0.885 & 0.912 & 0.900 & 0.878 & 0.873 & 0.877 \\
\hline
\end{tabular}

(Table 4 A continues at the next page...) 


\section{Table 4A: Inflation differentials in Euro area. GMM estimates for Eurostat quarterly data 1999-2007 (1 lag) (cont.)}

\begin{tabular}{|l|c|c|c|c|c|c|}
\hline & $(1)$ & $(2)$ & $(3)$ & $(4)$ & $(5)$ & $(6)$ \\
\hline EA15 & & & & & \\
\hline OG & -0.00277 & 0.00243 & 0.00231 & 0.0159 & 0.00230 & 0.00356 \\
& $(0.007)$ & $(0.004)$ & $(0.005)$ & $(0.010)$ & $(0.006)$ & $(0.006)$ \\
GGD & $2.54 \mathrm{e}-08$ & $3.13 \mathrm{e}-08$ & $2.42 \mathrm{e}-08$ & $2.77 \mathrm{e}-07 * * *$ & $5.98 \mathrm{e}-08^{*}$ & $6.18 \mathrm{e}-08 *$ \\
& $(0.000)$ & $(0.000)$ & $(0.000)$ & $(0.000)$ & $(0.000)$ & $(0.000)$ \\
DNEER_1 & $-0.00591 * * *$ & $-0.00301 * * *$ & $-0.00338^{* * *}$ & -0.00165 & $-0.00399 * * *$ & -0.000383 \\
& $(0.002)$ & $(0.001)$ & $(0.001)$ & $(0.002)$ & $(0.001)$ & $(0.001)$ \\
CPL_HFCE1 & -0.000162 & $-0.0168 * * *$ & $-0.0161 * * *$ & $-0.0318^{* * *}$ & $-0.0279 * * *$ & -0.0116 \\
& $(0.010)$ & $(0.005)$ & $(0.005)$ & $(0.011)$ & $(0.008)$ & $(0.007)$ \\
Adjusted $R^{2}$ & 0.893 & 0.914 & 0.897 & 0.883 & 0.888 & 0.885 \\
\hline
\end{tabular}

Notes: Models (1), (2), (3), (4), (5) and (6) include as dependent variable the growth rate in HICP, HICP less Energy, HICP less Energy and Unprocessed Foods, Labour Cost Index, GDP Deflator based on national currencies, and GDP Deflator based on Euro respectively. OG, DNEER 1, GGD andCPL_HFCEI account for Output Gap, lagged differenced Nominal Effective Exchange Rate, Government General Deficit and lagged Comparative Price Level (Household Final Consumption Expenditure) respectively. Output Gap (OG) and Government General Deficit (GGD) are instrumented by their lagged values. ***,** and * denote significance at the 1,5 and 10\% levels respectively. Time dummies included. Robust standard errors in parentheses. All computations done using commands for StataSE 10.0. 
Table 5A: Inflation differentials in Euro area. GMM estimates for Eurostat quarterly data 1999-2007 (4 lags)

\begin{tabular}{|c|c|c|c|c|c|c|}
\hline & (1) & (2) & (3) & (4) & (5) & (6) \\
\hline \multicolumn{7}{|l|}{ EA10 } \\
\hline$\overline{\mathrm{OG}}$ & $\begin{array}{c}0.131^{* * *} \\
(0.038)\end{array}$ & $\begin{array}{c}0.109^{* * *} \\
(0.032)\end{array}$ & $\begin{array}{c}0.107^{* * *} \\
(0.032)\end{array}$ & $\begin{array}{c}0.169^{* * *} \\
(0.050)\end{array}$ & $\begin{array}{c}0.117^{* * * *} \\
(0.034)\end{array}$ & $\begin{array}{c}0.117^{* * *} \\
(0.034)\end{array}$ \\
\hline GGD & $\begin{array}{c}1.75 \mathrm{e}-07 \\
(0.000)\end{array}$ & $\begin{array}{c}1.62 \mathrm{e}-07 \\
(0.000)\end{array}$ & $\begin{array}{c}1.79 \mathrm{e}-07 \\
(0.000)\end{array}$ & $\begin{array}{c}1.69 \mathrm{e}-07 \\
(0.000)\end{array}$ & $\begin{array}{c}1.03 \mathrm{e}-07 \\
(0.000)\end{array}$ & $\begin{array}{c}1.03 \mathrm{e}-07 \\
(0.000)\end{array}$ \\
\hline DNEER_4 & $\begin{array}{c}0.00583 \\
(0.015)\end{array}$ & $\begin{array}{c}0.00442 \\
(0.012)\end{array}$ & $\begin{array}{c}0.00439 \\
(0.012)\end{array}$ & $\begin{array}{c}0.00547 \\
(0.027)\end{array}$ & $\begin{array}{c}0.00409 \\
(0.014)\end{array}$ & $\begin{array}{c}0.00409 \\
(0.014)\end{array}$ \\
\hline CPL_HFCE4 & $\begin{array}{l}-0.0129 \\
(0.074)\end{array}$ & $\begin{array}{l}-0.0208 \\
(0.060)\end{array}$ & $\begin{array}{l}-0.0188 \\
(0.060)\end{array}$ & $\begin{array}{l}0.0215 \\
(0.071)\end{array}$ & $\begin{array}{c}-0.00772 \\
(0.065)\end{array}$ & $\begin{array}{c}-0.00772 \\
(0.065)\end{array}$ \\
\hline Adjusted $R^{2}$ & . & . & . & 0.057 & . & . \\
\hline \multicolumn{7}{|l|}{ EA11 } \\
\hline$\overline{\mathrm{OG}}$ & $\begin{array}{c}0.00265 \\
(0.004)\end{array}$ & $\begin{array}{c}0.000101 \\
(0.005)\end{array}$ & $\begin{array}{c}-0.00287 \\
(0.005)\end{array}$ & $\begin{array}{c}0.00930 \\
(0.011)\end{array}$ & $\begin{array}{c}-0.00932 \\
(0.008)\end{array}$ & $\begin{array}{c}-0.00968 \\
(0.008)\end{array}$ \\
\hline GGD & $\begin{array}{c}9.73 \mathrm{e}-08^{* * *} * \\
(0.000)\end{array}$ & $\begin{array}{c}8.92 \mathrm{e}-08^{* * *} * \\
(0.000)\end{array}$ & $\begin{array}{c}9.69 \mathrm{e}-08^{* * *} * \\
(0.000)\end{array}$ & $\begin{array}{c}1.31 \mathrm{e}-07 \\
(0.000)\end{array}$ & $\begin{array}{c}1.02 \mathrm{e}-07^{* *} \\
(0.000)\end{array}$ & $\begin{array}{c}1.02 \mathrm{e}-07 * * \\
(0.000)\end{array}$ \\
\hline DNEER_4 & $\begin{array}{c}6.86 \mathrm{e}-05 \\
(0.001)\end{array}$ & $\begin{array}{c}-0.000522 \\
(0.001)\end{array}$ & $\begin{array}{c}-0.000679 \\
(0.001)\end{array}$ & $\begin{array}{c}-0.00162 \\
(0.015)\end{array}$ & $\begin{array}{c}-0.00144 \\
(0.002)\end{array}$ & $\begin{array}{c}-0.00148 \\
(0.002)\end{array}$ \\
\hline CPL_HFCE4 & $\begin{array}{c}-0.0289^{* * *} \\
(0.010)\end{array}$ & $\begin{array}{c}-0.0332 * * * \\
(0.011)\end{array}$ & $\begin{array}{c}-0.0343 * * * \\
(0.012)\end{array}$ & $\begin{array}{c}0.00504 \\
(0.318)\end{array}$ & $\begin{array}{l}-0.0256 \\
(0.024)\end{array}$ & $\begin{array}{l}-0.0257 \\
(0.023)\end{array}$ \\
\hline Adjusted $R^{2}$ & 0.934 & 0.910 & 0.895 & 0.893 & 0.867 & 0.869 \\
\hline \multicolumn{7}{|l|}{ EA12 } \\
\hline OG & $\begin{array}{c}-0.0554 \\
(0.061)\end{array}$ & $\begin{array}{l}-0.0555 \\
(0.062)\end{array}$ & $\begin{array}{c}-0.0657 \\
(0.073)\end{array}$ & $\begin{array}{l}-0.0503 \\
(0.073)\end{array}$ & $\begin{array}{c}-0.0725 \\
(0.081)\end{array}$ & $\begin{array}{l}-0.0704 \\
(0.079)\end{array}$ \\
\hline GGD & $\begin{array}{c}1.77 \mathrm{e}-07^{*} \\
(0.000)\end{array}$ & $\begin{array}{c}1.64 \mathrm{e}-07 * \\
(0.000)\end{array}$ & $\begin{array}{c}1.77 \mathrm{e}-07 \\
(0.000)\end{array}$ & $\begin{array}{c}1.72 \mathrm{e}-07 \\
(0.000)\end{array}$ & $\begin{array}{c}1.78 \mathrm{e}-07 \\
(0.000)\end{array}$ & $\begin{array}{c}1.75 \mathrm{e}-07 \\
(0.000)\end{array}$ \\
\hline DNEER_4 & $\begin{array}{c}-0.00213 \\
(0.003)\end{array}$ & $\begin{array}{c}-0.00240 \\
(0.003)\end{array}$ & $\begin{array}{c}-0.00259 \\
(0.003)\end{array}$ & $\begin{array}{c}-0.00289 \\
(0.003)\end{array}$ & $\begin{array}{c}-0.00227 \\
(0.004)\end{array}$ & $\begin{array}{c}-0.00226 \\
(0.004)\end{array}$ \\
\hline CPL_HFCE4 & $\begin{array}{r}-0.0334 \\
(0.028)\end{array}$ & $\begin{array}{r}-0.0367 \\
(0.028)\end{array}$ & $\begin{array}{c}-0.0381 \\
(0.033)\end{array}$ & $\begin{array}{r}-0.0149 \\
(0.033)\end{array}$ & $\begin{array}{l}-0.0369 \\
(0.036)\end{array}$ & $\begin{array}{c}-0.0380 \\
(0.036)\end{array}$ \\
\hline Adjusted $R^{2}$ & 0.644 & 0.553 & 0.383 & 0.757 & 0.422 & 0.446 \\
\hline \multicolumn{7}{|l|}{ EA13 } \\
\hline $\mathrm{OG}$ & $\begin{array}{c}-0.0708 \\
(0.082)\end{array}$ & $\begin{array}{c}-0.0568 \\
(0.067)\end{array}$ & $\begin{array}{l}-0.0688 \\
(0.080)\end{array}$ & $\begin{array}{c}-0.0559 \\
(0.081)\end{array}$ & $\begin{array}{l}-0.0814 \\
(0.094)\end{array}$ & $\begin{array}{l}-0.0699 \\
(0.085)\end{array}$ \\
\hline GGD & $\begin{array}{c}2.03 \mathrm{e}-07 * \\
(0.000)\end{array}$ & $\begin{array}{c}1.47 \mathrm{e}-07 \\
(0.000)\end{array}$ & $\begin{array}{c}1.61 \mathrm{e}-07 \\
(0.000)\end{array}$ & $\begin{array}{c}1.95 \mathrm{e}-07 * \\
(0.000)\end{array}$ & $\begin{array}{c}1.71 \mathrm{e}-07 \\
(0.000)\end{array}$ & $\begin{array}{c}1.53 \mathrm{e}-07 \\
(0.000)\end{array}$ \\
\hline DNEER_4 & $\begin{array}{c}-0.00120 \\
(0.002)\end{array}$ & $\begin{array}{c}-0.00170 \\
(0.002)\end{array}$ & $\begin{array}{c}-0.00170 \\
(0.002)\end{array}$ & $\begin{array}{c}-0.00169 \\
(0.002)\end{array}$ & $\begin{array}{c}-0.00120 \\
(0.002)\end{array}$ & $\begin{array}{c}0.000179 \\
(0.002)\end{array}$ \\
\hline CPL_HFCE4 & $\begin{array}{r}-0.0149 \\
(0.022)\end{array}$ & $\begin{array}{l}-0.0314 \\
(0.020)\end{array}$ & $\begin{array}{l}-0.0316 \\
(0.024)\end{array}$ & $\begin{array}{l}-0.0287 \\
(0.020)\end{array}$ & $\begin{array}{l}-0.0228 \\
(0.024)\end{array}$ & $\begin{array}{c}-0.00422 \\
(0.022)\end{array}$ \\
\hline Adjusted $R^{2}$ & 0.534 & 0.534 & 0.333 & 0.754 & 0.381 & 0.466 \\
\hline
\end{tabular}


Table 5A: Inflation differentials in Euro area. GMM estimates for Eurostat quarterly data 1999-2007 (4 lags) (cont.)

\begin{tabular}{|l|c|c|c|c|c|c|}
\hline & $(1)$ & $(2)$ & $(3)$ & $(4)$ & $(5)$ & $(6)$ \\
\hline EA15 & & & & & & \\
\hline OG & -0.0538 & -0.0430 & -0.0499 & -0.0546 & -0.0488 & -0.0439 \\
& $(0.050)$ & $(0.042)$ & $(0.048)$ & $(0.060)$ & $(0.047)$ & $(0.047)$ \\
GGD & $1.75 \mathrm{e}-07 * *$ & $1.12 \mathrm{e}-07 *$ & $1.16 \mathrm{e}-07$ & $2.11 \mathrm{e}-07 * *$ & $1.61 \mathrm{e}-07 *$ & $1.37 \mathrm{e}-07 *$ \\
& $(0.000)$ & $(0.000)$ & $(0.000)$ & $(0.000)$ & $(0.000)$ & $(0.000)$ \\
DNEER_4 & -0.00190 & $-0.00293 * *$ & $-0.00341 * * *$ & -0.000998 & -0.00165 & 0.000130 \\
& $(0.002)$ & $(0.001)$ & $(0.001)$ & $(0.002)$ & $(0.001)$ & $(0.001)$ \\
CPL_HFCE4 & -0.00996 & -0.0197 & -0.0167 & -0.0153 & -0.00839 & 0.00289 \\
& $(0.016)$ & $(0.012)$ & $(0.014)$ & $(0.018)$ & $(0.015)$ & $(0.014)$ \\
Adjusted $R^{2}$ & 0.668 & 0.675 & 0.560 & 0.762 & 0.696 & 0.696 \\
\hline
\end{tabular}

Notes: Models (1), (2), (3), (4), (5) and (6) include as dependent variable the growth rate in HICP, HICP less Energy, HICP less Energy and Unprocessed Foods, Labour Cost Index, GDP Deflator based on national currencies, and GDP Deflator based on Euro respectively. OG, DNEER 1, GGD andCPL_HFCE1 account for Output Gap, lagged differenced Nominal Effective Exchange Rate, Government General Deficit and lagged Comparative Price Level (Household Final Consumption Expenditure) respectively. Output Gap (OG) and Government General Deficit (GGD) are instrumented by their lagged values. $* * *, * *$ and $*$ denote significance at the 1,5 and $10 \%$ levels respectively. Time dummies included. Robust standard errors in parentheses. All computations done using commands for StataSE 10.0. 


\subsection{GMM estimates - modified specifications}

Table 6A: Inflation differentials in Euro area I., GMM estimates for OECD yearly data, 1999-2007

\begin{tabular}{|l|c|c|c|c|c|c|c|}
\hline & $(1)$ & $(2)$ & $(3)$ & $(4)$ & $(5)$ & $(6)$ & $(7)$ \\
\hline EA10 & & & & & & & \\
\hline OG & $0.00544^{* * *}$ & $0.00584^{* * *}$ & $0.00620^{* * *}$ & $0.0168^{* * *}$ & $0.00729^{* * *}$ & $0.00765^{* * *}$ & $0.00562^{* * *}$ \\
& $(0.001)$ & $(0.001)$ & $(0.001)$ & $(0.003)$ & $(0.001)$ & $(0.001)$ & $(0.001)$ \\
DNEER_1 & -0.000270 & -0.000493 & -0.000666 & 0.000296 & -0.000510 & -0.000393 & -0.000468 \\
& $(0.000)$ & $(0.000)$ & $(0.000)$ & $(0.001)$ & $(0.001)$ & $(0.001)$ & $(0.001)$ \\
PPP_1 & $-0.0382^{* * *}$ & $-0.0441^{* * *}$ & $-0.0409 * * *$ & -0.00630 & $-0.0641 * * *$ & $-0.0342^{* * *}$ & $-0.0410^{* * *}$ \\
& $(0.009)$ & $(0.009)$ & $(0.009)$ & $(0.025)$ & $(0.012)$ & $(0.012)$ & $(0.011)$ \\
Adjusted $R^{2}$ & 0.482 & 0.611 & 0.547 & 0.415 & 0.579 & 0.503 & 0.477 \\
\hline EA11 & & & & & & & \\
\hline OG & $0.00448^{* * *}$ & $0.00476^{* * *}$ & $0.00532^{* * *}$ & $0.0168^{* * *}$ & $0.00617^{* * *}$ & $0.00610^{* * *}$ & $0.00503 * * *$ \\
& $(0.001)$ & $(0.001)$ & $(0.001)$ & $(0.003)$ & $(0.001)$ & $(0.001)$ & $(0.001)$ \\
DNEER_1 & -0.000158 & -0.000336 & -0.000497 & 0.000295 & -0.000230 & -0.000105 & -0.000312 \\
& $(0.000)$ & $(0.000)$ & $(0.000)$ & $(0.001)$ & $(0.001)$ & $(0.001)$ & $(0.001)$ \\
PPP_1 & $-0.0406^{* * *}$ & $-0.0465^{* * *}$ & $-0.0451^{* * *}$ & -0.00630 & $-0.0604 * * *$ & $-0.0324 * * *$ & $-0.0378^{* * *}$ \\
& $(0.007)$ & $(0.007)$ & $(0.007)$ & $(0.025)$ & $(0.009)$ & $(0.010)$ & $(0.009)$ \\
Adjusted $R^{2}$ & 0.521 & 0.636 & 0.575 & 0.415 & 0.550 & 0.440 & 0.461 \\
\hline EA12 & & & & & & & \\
\hline OG & $0.00437^{* * *}$ & $0.00475^{* * *}$ & $0.00539^{* * *}$ & $0.0162^{* * *}$ & $0.00517^{* * *}$ & $0.00614^{* * *}$ & $0.00472^{* * *}$ \\
& $(0.001)$ & $(0.001)$ & $(0.001)$ & $(0.003)$ & $(0.001)$ & $(0.001)$ & $(0.001)$ \\
DNEER_1 & -0.00332 & -0.000468 & -0.000611 & -0.000507 & -0.000783 & $-9.69 \mathrm{e}-05$ & -0.000463 \\
& $(0.000)$ & $(0.000)$ & $(0.000)$ & $(0.001)$ & $(0.001)$ & $(0.001)$ & $(0.000)$ \\
PPP_1 & $-0.0354 * * *$ & $-0.0412^{* * *}$ & $-0.0402^{* * *}$ & 0.0256 & $-0.0477 * * *$ & $-0.0319^{* * * *}$ & $-0.0340^{* * *}$ \\
& $(0.006)$ & $(0.007)$ & $(0.007)$ & $(0.023)$ & $(0.011)$ & $(0.010)$ & $(0.008)$ \\
Adjusted $R^{2}$ & 0.453 & 0.585 & 0.516 & 0.383 & 0.334 & 0.387 & 0.432 \\
\hline
\end{tabular}

Notes: Models (1), (2), (3), (4), (5), (6) and (7) include as dependent variable the growth rate in HICP, HICP less Energy, HICP less Energy and Unprocessed Foods, Wages, GDP Deflator, Total Domestic Expenditure Deflator and Private Final Consumption Expenditure Deflator respectively. OG, DNEER 1, GPB CA and PPP 1 account for Output Gap, lagged differenced Nominal Effective Exchange Rate, Cyclically Adjusted Government Primary Balance and lagged Price Level Indicator based on PPP respectively. Output Gap (OG) and Cyclically Adjusted Government Primary Balance $(G P B)$ are instrumented by their lagged values. ***,** and * denote significance at 1,5 and $10 \%$ levels respectively. Time dummies included. Robust standard errors in parentheses. All computations done using commands for StataSE 10.0. 
Table 7A: Inflation differentials in the Euro area I., GMM estimates for Eurostat yearly data 1999-2007

\begin{tabular}{|c|c|c|c|c|c|c|}
\hline & (1) & (2) & (3) & (4) & $(5)$ & $(6)$ \\
\hline \multicolumn{7}{|l|}{ EA10 } \\
\hline $\mathrm{OG}$ & $\begin{array}{c}0.00723 * * * \\
(0.001)\end{array}$ & $\begin{array}{c}0.00793 * * * \\
(0.001)\end{array}$ & $\begin{array}{c}0.00817 * * * \\
(0.001)\end{array}$ & $\begin{array}{c}0.0111 * * * \\
(0.002)\end{array}$ & $\begin{array}{c}0.0100 * * * \\
(0.001)\end{array}$ & $\begin{array}{c}0.00998 * * * \\
(0.001)\end{array}$ \\
\hline DNEER_1 & $\begin{array}{c}-0.000601 \\
(0.001)\end{array}$ & $\begin{array}{c}-0.000652 \\
(0.001)\end{array}$ & $\begin{array}{c}-0.000849 \\
(0.001)\end{array}$ & $\begin{array}{c}-0.000994 \\
(0.001)\end{array}$ & $\begin{array}{c}-0.000996 \\
(0.001)\end{array}$ & $\begin{array}{c}-0.00112 \\
(0.001)\end{array}$ \\
\hline CPL_HFCF1 & $\begin{array}{c}-0.0385 * * * \\
(0.006)\end{array}$ & $\begin{array}{c}-0.0453 * * * \\
(0.005)\end{array}$ & $\begin{array}{c}-0.0432 * * * \\
(0.005)\end{array}$ & $\begin{array}{c}-0.00678 \\
(0.010)\end{array}$ & $\begin{array}{c}-0.0631 * * * \\
(0.008)\end{array}$ & $\begin{array}{c}-0.0627 * * * \\
(0.008)\end{array}$ \\
\hline Adjusted $R^{2}$ & 0.495 & 0.629 & 0.552 & 0.329 & 0.535 & 0.524 \\
\hline \multicolumn{7}{|l|}{ EA11 } \\
\hline $\mathrm{OG}$ & $\begin{array}{c}0.00610 * * * \\
(0.001)\end{array}$ & $\begin{array}{c}0.00658 * * * \\
(0.001)\end{array}$ & $\begin{array}{c}0.00716 * * * \\
(0.001)\end{array}$ & $\begin{array}{c}0.00942 * * * \\
(0.002)\end{array}$ & $\begin{array}{c}0.00858 * * * \\
(0.001)\end{array}$ & $\begin{array}{c}0.00897 * * * \\
(0.001)\end{array}$ \\
\hline DNEER_1 & $\begin{array}{c}-0.000661 \\
(0.001)\end{array}$ & $\begin{array}{c}-0.000730 \\
(0.001)\end{array}$ & $\begin{array}{c}-0.00101 \\
(0.001)\end{array}$ & $\begin{array}{c}-0.000828 \\
(0.001)\end{array}$ & $\begin{array}{c}-0.00120 \\
(0.001)\end{array}$ & $\begin{array}{c}-0.00117 \\
(0.001)\end{array}$ \\
\hline CPL_HFCF1 & $\begin{array}{c}-0.0364 * * * \\
(0.005)\end{array}$ & $\begin{array}{c}-0.0420 * * * \\
(0.005)\end{array}$ & $\begin{array}{c}-0.0412 * * * \\
(0.005)\end{array}$ & $\begin{array}{r}-0.0207 \\
(0.014)\end{array}$ & $\begin{array}{c}-0.0520 * * * \\
(0.007)\end{array}$ & $\begin{array}{c}-0.0502 * * * \\
(0.007)\end{array}$ \\
\hline Adjusted $R^{2}$ & 0.527 & 0.650 & 0.585 & 0.276 & 0.529 & 0.499 \\
\hline \multicolumn{7}{|l|}{ EA12 } \\
\hline $\mathrm{OG}$ & $\begin{array}{c}0.00575 * * * \\
(0.001)\end{array}$ & $\begin{array}{c}0.00653 * * * \\
(0.001)\end{array}$ & $\begin{array}{c}0.00720 * * * \\
(0.001)\end{array}$ & $\begin{array}{c}0.00940 * * * \\
(0.003)\end{array}$ & $\begin{array}{c}0.00686 * * * \\
(0.002)\end{array}$ & $\begin{array}{c}0.00720 * * * \\
(0.002)\end{array}$ \\
\hline DNEER_1 & $\begin{array}{c}-0.000770 \\
(0.001)\end{array}$ & $\begin{array}{c}-0.000851 \\
(0.001)\end{array}$ & $\begin{array}{c}-0.00112 \\
(0.001)\end{array}$ & $\begin{array}{c}-0.000636 \\
(0.001)\end{array}$ & $\begin{array}{c}-0.00188^{*} \\
(0.001)\end{array}$ & $\begin{array}{c}-0.00183^{*} \\
(0.001)\end{array}$ \\
\hline CPL_HFCF1 & $\begin{array}{c}-0.0345 * * * \\
(0.005)\end{array}$ & $\begin{array}{c}-0.0402 * * * \\
(0.005)\end{array}$ & $\begin{array}{c}-0.0397 * * * \\
(0.005)\end{array}$ & $\begin{array}{c}-0.0216 \\
(0.014)\end{array}$ & $\begin{array}{c}-0.0470 * * * \\
(0.007)\end{array}$ & $\begin{array}{c}-0.0450 * * * \\
(0.007)\end{array}$ \\
\hline Adjusted $R^{2}$ & 0.468 & 0.608 & 0.542 & 0.256 & 0.289 & 0.265 \\
\hline \multicolumn{7}{|l|}{ EA13 } \\
\hline $\mathrm{OG}$ & $\begin{array}{c}0.00516 * * * \\
(0.001)\end{array}$ & $\begin{array}{c}0.00577 * * * \\
(0.001)\end{array}$ & $\begin{array}{c}0.00636 * * * \\
(0.001)\end{array}$ & $\begin{array}{c}0.00858 * * * \\
(0.003)\end{array}$ & $\begin{array}{c}0.00652 * * * \\
(0.002)\end{array}$ & $\begin{array}{c}0.00736^{* * *} * \\
(0.002)\end{array}$ \\
\hline DNEER_1 & $\begin{array}{c}-0.00146 \\
(0.001)\end{array}$ & $\begin{array}{c}-0.00243^{* * *} \\
(0.001)\end{array}$ & $\begin{array}{c}-0.00289 * * * \\
(0.001)\end{array}$ & $\begin{array}{c}-0.00156 \\
(0.002)\end{array}$ & $\begin{array}{c}-0.00221 * \\
(0.001)\end{array}$ & $\begin{array}{c}-0.00117 \\
(0.001)\end{array}$ \\
\hline CPL_HFCF1 & $\begin{array}{c}-0.0577 * * * \\
(0.011)\end{array}$ & $\begin{array}{c}-0.0464 * * * \\
(0.007)\end{array}$ & $\begin{array}{c}-0.0460 * * * \\
(0.007)\end{array}$ & $\begin{array}{c}-0.0646 * * * \\
(0.018)\end{array}$ & $\begin{array}{c}-0.0624 * * * \\
(0.012)\end{array}$ & $\begin{array}{c}-0.0320 * * * \\
(0.007)\end{array}$ \\
\hline Adjusted $R^{2}$ & 0.382 & 0.599 & 0.553 & 0.203 & 0.304 & 0.234 \\
\hline \multicolumn{7}{|l|}{ EA15 } \\
\hline $\mathrm{OG}$ & $\begin{array}{c}0.00361 * * * \\
(0.001)\end{array}$ & $\begin{array}{c}0.00390 * * * \\
(0.001)\end{array}$ & $\begin{array}{c}0.00452 * * * \\
(0.001)\end{array}$ & $\begin{array}{c}0.00710 * * * \\
(0.003)\end{array}$ & $\begin{array}{c}0.00568 * * * \\
(0.002)\end{array}$ & $\begin{array}{c}0.00657 * * * \\
(0.002)\end{array}$ \\
\hline DNEER_1 & $\begin{array}{c}-0.000316 \\
(0.001)\end{array}$ & $\begin{array}{c}-0.000629 \\
(0.001)\end{array}$ & $\begin{array}{c}-0.00111 \\
(0.001)\end{array}$ & $\begin{array}{c}-0.000425 \\
(0.001)\end{array}$ & $\begin{array}{c}-0.000702 \\
(0.001)\end{array}$ & $\begin{array}{c}9.09 \mathrm{e}-05 \\
(0.001)\end{array}$ \\
\hline CPL_HFCF1 & $\begin{array}{c}-0.0402 * * * \\
(0.008)\end{array}$ & $\begin{array}{c}-0.0342 * * * \\
(0.006)\end{array}$ & $\begin{array}{c}-0.0345^{* * *} \\
(0.006)\end{array}$ & $\begin{array}{c}-0.0559 * * * \\
(0.013)\end{array}$ & $\begin{array}{c}-0.0565 * * * \\
(0.009)\end{array}$ & $\begin{array}{c}-0.0297 * * * \\
(0.008)\end{array}$ \\
\hline Adjusted $R^{2}$ & 0.248 & 0.418 & 0.377 & 0.172 & 0.239 & 0.159 \\
\hline
\end{tabular}

Notes: Models (1), (2), (3), (4), (5) and (6) include as dependent variable the growth rate in HICP, HICP less Energy and Unprocessed Foods, Labour Cost Index, GDP Deflator based on national currencies, and GDP Deflator based on Euro respectively. OG, DNEER 4, GGD and CPL HFCE4 account for Output Gap, lagged differenced Nominal Effective Exchange Rate, Government General Deficit and lagged Comparative Price Level (Household Final Consumption Expenditure) respectively. Output Gap $(O G)$ is instrumented by their lagged values. ***,** and * denote significance at the 1, 5 and $10 \%$ levels respectively. Robust standard errors in parentheses. All computations done using commands for StataSE 10.0. 
Table 8A: Inflation differentials in the Euro area I., GMM estimates for Eurostat quarterly data 1999-2007 (1 lag)

\begin{tabular}{|c|c|c|c|c|c|c|}
\hline & $(1)$ & (2) & (3) & (4) & (5) & (6) \\
\hline \multicolumn{7}{|l|}{ EA10 } \\
\hline OG & $\begin{array}{c}0.00800^{*} \\
(0.004)\end{array}$ & $\begin{array}{c}0.00694 \\
(0.004)\end{array}$ & $\begin{array}{c}0.00872^{*} \\
(0.005)\end{array}$ & $\begin{array}{c}0.0208^{* *} \\
(0.008)\end{array}$ & $\begin{array}{c}0.0133^{*} \\
(0.007)\end{array}$ & $\begin{array}{c}0.0144 * * \\
(0.007)\end{array}$ \\
\hline DNEER_1 & $\begin{array}{c}-0.000804 \\
(0.001)\end{array}$ & $\begin{array}{c}-0.000889 \\
(0.001)\end{array}$ & $\begin{array}{c}-0.00114^{*} \\
(0.001)\end{array}$ & $\begin{array}{c}-0.00240^{* *} \\
(0.001)\end{array}$ & $\begin{array}{c}-0.00194^{* *} \\
(0.001)\end{array}$ & $\begin{array}{c}-0.00178^{*} \\
(0.001)\end{array}$ \\
\hline CPL_HFCF1 & $\begin{array}{c}-0.0269 * * * \\
(0.005)\end{array}$ & $\begin{array}{c}-0.0316^{* * *} \\
(0.005)\end{array}$ & $\begin{array}{c}-0.0290 * * * \\
(0.005)\end{array}$ & $\begin{array}{l}0.0108 \\
(0.010)\end{array}$ & $\begin{array}{c}-0.0469 * * * \\
(0.007)\end{array}$ & $\begin{array}{c}-0.0471 * * * \\
(0.007)\end{array}$ \\
\hline Adjusted $R^{2}$ & 0.229 & 0.393 & 0.254 & . & 0.145 & 0.090 \\
\hline \multicolumn{7}{|l|}{ EA11 } \\
\hline OG & $\begin{array}{c}0.00369 \\
(0.006)\end{array}$ & $\begin{array}{c}0.00305 \\
(0.006)\end{array}$ & $\begin{array}{c}0.00425 \\
(0.007)\end{array}$ & $\begin{array}{c}0.0247 * * \\
(0.013)\end{array}$ & $\begin{array}{c}0.00853 \\
(0.008)\end{array}$ & $\begin{array}{c}0.00985 \\
(0.007)\end{array}$ \\
\hline DNEER_1 & $\begin{array}{c}0.00189 \\
(0.001)\end{array}$ & $\begin{array}{c}0.00226^{*} \\
(0.001)\end{array}$ & $\begin{array}{c}0.00180 \\
(0.001)\end{array}$ & $\begin{array}{c}0.00489 * * \\
(0.002)\end{array}$ & $\begin{array}{c}0.000725 \\
(0.002)\end{array}$ & $\begin{array}{c}0.000706 \\
(0.002)\end{array}$ \\
\hline CPL_HFCF1 & $\begin{array}{c}-0.0117^{*} \\
(0.007)\end{array}$ & $\begin{array}{c}-0.0143 * \\
(0.007)\end{array}$ & $\begin{array}{r}-0.0129 \\
(0.008)\end{array}$ & $\begin{array}{c}-0.0244 \\
(0.016)\end{array}$ & $\begin{array}{c}-0.0383 * * * \\
(0.011)\end{array}$ & $\begin{array}{c}-0.0363^{* * *} \\
(0.011)\end{array}$ \\
\hline Adjusted $R^{2}$ & 0.941 & 0.919 & 0.907 & 0.880 & 0.874 & 0.875 \\
\hline \multicolumn{7}{|l|}{ EA12 } \\
\hline OG & $\begin{array}{c}0.00488^{*} \\
(0.003)\end{array}$ & $\begin{array}{c}0.00438^{*} \\
(0.003)\end{array}$ & $\begin{array}{c}0.00565^{* *} \\
(0.003)\end{array}$ & $\begin{array}{c}0.00914^{*} \\
(0.005)\end{array}$ & $\begin{array}{c}0.00854 \\
(0.006)\end{array}$ & $\begin{array}{c}0.0104 * \\
(0.006)\end{array}$ \\
\hline DNEER_1 & $\begin{array}{c}-0.000221 \\
(0.000)\end{array}$ & $\begin{array}{c}-0.000414 \\
(0.000)\end{array}$ & $\begin{array}{c}-0.000787 \\
(0.001)\end{array}$ & $\begin{array}{c}-0.000378 \\
(0.001)\end{array}$ & $\begin{array}{c}-0.00230^{* * *} \\
(0.001)\end{array}$ & $\begin{array}{c}-0.00209^{* * *} \\
(0.001)\end{array}$ \\
\hline CPL_HFCF1 & $\begin{array}{c}-0.0302 * * * \\
(0.004)\end{array}$ & $\begin{array}{c}-0.0344 * * * \\
(0.004)\end{array}$ & $\begin{array}{c}-0.0332 * * * \\
(0.004)\end{array}$ & $\begin{array}{c}-0.0177^{*} \\
(0.009)\end{array}$ & $\begin{array}{c}-0.0404 * * * \\
(0.005)\end{array}$ & $\begin{array}{c}-0.0385 * * * \\
(0.006)\end{array}$ \\
\hline Adjusted $R^{2}$ & 0.227 & 0.399 & 0.269 & -0.015 & 0.046 & -0.029 \\
\hline \multicolumn{7}{|l|}{ EA13 } \\
\hline OG & $\begin{array}{c}0.00671^{*} \\
(0.004)\end{array}$ & $\begin{array}{c}0.00555^{* *} \\
(0.003)\end{array}$ & $\begin{array}{c}0.00673^{* *} \\
(0.003)\end{array}$ & $\begin{array}{c}0.00837 \\
(0.006)\end{array}$ & $\begin{array}{c}0.00989 \\
(0.006)\end{array}$ & $\begin{array}{c}0.0104^{*} \\
(0.006)\end{array}$ \\
\hline DNEER_1 & $\begin{array}{c}-0.00182^{* * *} \\
(0.001)\end{array}$ & $\begin{array}{c}-0.00252^{* * * *} \\
(0.001)\end{array}$ & $\begin{array}{c}-0.00293^{* * * *} \\
(0.001)\end{array}$ & $\begin{array}{c}-0.00232 * * \\
(0.001)\end{array}$ & $\begin{array}{c}-0.00278^{* * *} * \\
(0.001)\end{array}$ & $\begin{array}{c}-0.000961 \\
(0.001)\end{array}$ \\
\hline CPL_HFCF1 & $\begin{array}{c}-0.0491 * * * \\
(0.006)\end{array}$ & $\begin{array}{c}-0.0376^{* * *} \\
(0.004)\end{array}$ & $\begin{array}{c}-0.0368 * * * \\
(0.004)\end{array}$ & $\begin{array}{c}-0.0512 * * * \\
(0.009)\end{array}$ & $\begin{array}{c}-0.0514 * * * \\
(0.007)\end{array}$ & $\begin{array}{c}-0.0224 * * * \\
(0.006)\end{array}$ \\
\hline Adjusted $R^{2}$ & 0.323 & 0.505 & 0.430 & 0.125 & 0.181 & -0.074 \\
\hline \multicolumn{7}{|l|}{ EA15 } \\
\hline $\mathrm{OG}$ & $\begin{array}{c}0.000699 \\
(0.006)\end{array}$ & $\begin{array}{c}0.00453 \\
(0.004)\end{array}$ & $\begin{array}{c}0.00443 \\
(0.004)\end{array}$ & $\begin{array}{c}0.0155^{*} \\
(0.009)\end{array}$ & $\begin{array}{c}0.00484 \\
(0.005)\end{array}$ & $\begin{array}{c}0.00385 \\
(0.005)\end{array}$ \\
\hline DNEER_1 & $\begin{array}{c}-0.00453^{* * * *} \\
(0.001)\end{array}$ & $\begin{array}{c}-0.00180^{* * * *} \\
(0.001)\end{array}$ & $\begin{array}{c}-0.00219^{* * * *} \\
(0.001)\end{array}$ & $\begin{array}{c}-0.00193 \\
(0.001)\end{array}$ & $\begin{array}{c}-0.00321 * * * \\
(0.001)\end{array}$ & $\begin{array}{c}-0.000731 \\
(0.001)\end{array}$ \\
\hline CPL_HFCF1 & $\begin{array}{c}-0.00242 \\
(0.010)\end{array}$ & $\begin{array}{c}-0.0200 * * * \\
(0.005)\end{array}$ & $\begin{array}{c}-0.0191 * * * \\
(0.005)\end{array}$ & $\begin{array}{c}-0.0429 * * * \\
(0.010)\end{array}$ & $\begin{array}{c}-0.0316^{* * *} \\
(0.008)\end{array}$ & $\begin{array}{c}-0.0123 * \\
(0.007)\end{array}$ \\
\hline Adjusted $R^{2}$ & 0.892 & 0.912 & 0.895 & 0.883 & 0.887 & 0.886 \\
\hline
\end{tabular}

Notes: Models (1), (2), (3), (4), (5) and (6) include as dependent variable the growth rate in HICP, HICP less Energy and Unprocessed Foods, Labour Cost Index, GDP Deflator based on national currencies, and GDP Deflator based on Euro respectively. OG, DNEER 4, GGD and CPL HFCE4 account for Output Gap, lagged differenced Nominal Effective Exchange Rate, Government General Deficit and lagged Comparative Price Level (Household Final Consumption Expenditure) respectively. Output Gap $(O G)$ is instrumented by their lagged values. ***,** and * denote significance at the 1,5 and $10 \%$ levels respectively. Robust standard errors in parentheses. All computations done using commands for StataSE 10.0. 
Table 9A: Inflation differentials in the Euro area I., GMM estimates for Eurostat quarterly data 1999-2007 (4 lags)

\begin{tabular}{|c|c|c|c|c|c|c|}
\hline & (1) & (2) & (3) & (4) & $(5)$ & (6) \\
\hline \multicolumn{7}{|l|}{ EA10 } \\
\hline $\mathrm{OG}$ & $\begin{array}{l}0.0540 \\
(0.078)\end{array}$ & $\begin{array}{l}0.0575 \\
(0.084)\end{array}$ & $\begin{array}{l}0.0619 \\
(0.091)\end{array}$ & $\begin{array}{l}0.0390 \\
(0.067)\end{array}$ & $\begin{array}{l}0.0727 \\
(0.108)\end{array}$ & $\begin{array}{c}0.0773 \\
(0.114)\end{array}$ \\
\hline DNEER_4 & $\begin{array}{c}-4.94 \mathrm{e}-05 \\
(0.001)\end{array}$ & $\begin{array}{c}-0.000118 \\
(0.002)\end{array}$ & $\begin{array}{c}-0.000326 \\
(0.002)\end{array}$ & $\begin{array}{c}-0.000339 \\
(0.001)\end{array}$ & $\begin{array}{c}-0.000268 \\
(0.002)\end{array}$ & $\begin{array}{c}-0.000371 \\
(0.002)\end{array}$ \\
\hline CPL_HFCF4 & $\begin{array}{c}-0.0386 * * \\
(0.018)\end{array}$ & $\begin{array}{c}-0.0447 * * \\
(0.019)\end{array}$ & $\begin{array}{c}-0.0429 * * \\
(0.021)\end{array}$ & $\begin{array}{c}-0.000488 \\
(0.015)\end{array}$ & $\begin{array}{c}-0.0635 * * * \\
(0.024)\end{array}$ & $\begin{array}{c}-0.0636 * * \\
(0.025)\end{array}$ \\
\hline Adjusted $R^{2}$ & . & . & . &. & $x^{\circ}$ & 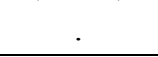 \\
\hline \multicolumn{7}{|l|}{ EA11 } \\
\hline $\mathrm{OG}$ & $\begin{array}{c}0.114 \\
(0.220)\end{array}$ & $\begin{array}{c}0.106 \\
(0.204)\end{array}$ & $\begin{array}{c}0.132 \\
(0.254)\end{array}$ & $\begin{array}{l}0.0703 \\
(0.132)\end{array}$ & $\begin{array}{c}0.172 \\
(0.320)\end{array}$ & $\begin{array}{c}0.176 \\
(0.328)\end{array}$ \\
\hline DNEER_4 & $\begin{array}{c}-0.000402 \\
(0.004)\end{array}$ & $\begin{array}{c}-0.000760 \\
(0.004)\end{array}$ & $\begin{array}{c}-0.000824 \\
(0.005)\end{array}$ & $\begin{array}{c}-0.00114 \\
(0.003)\end{array}$ & $\begin{array}{c}-0.00134 \\
(0.006)\end{array}$ & $\begin{array}{c}-0.00125 \\
(0.007)\end{array}$ \\
\hline CPL_HFCF4 & $\begin{array}{c}0.00861 \\
(0.069)\end{array}$ & $\begin{array}{c}0.00317 \\
(0.065)\end{array}$ & $\begin{array}{l}0.0123 \\
(0.081)\end{array}$ & $\begin{array}{l}0.0105 \\
(0.045)\end{array}$ & $\begin{array}{l}0.0295 \\
(0.103)\end{array}$ & $\begin{array}{l}0.0307 \\
(0.105)\end{array}$ \\
\hline Adjusted $R^{2}$ & 0.076 & . & . & 0.755 & . & . \\
\hline \multicolumn{7}{|l|}{ EA12 } \\
\hline $\mathrm{OG}$ & $\begin{array}{l}0.0810 \\
(0.251)\end{array}$ & $\begin{array}{l}0.0900 \\
(0.277)\end{array}$ & $\begin{array}{c}0.121 \\
(0.374)\end{array}$ & $\begin{array}{l}0.0954 \\
(0.303)\end{array}$ & $\begin{array}{l}0.0530 \\
(0.173)\end{array}$ & $\begin{array}{l}0.0719 \\
(0.227)\end{array}$ \\
\hline DNEER_4 & $\begin{array}{c}-0.00237 \\
(0.008)\end{array}$ & $\begin{array}{c}-0.00269 \\
(0.009)\end{array}$ & $\begin{array}{c}-0.00380 \\
(0.012)\end{array}$ & $\begin{array}{c}-0.00252 \\
(0.010)\end{array}$ & $\begin{array}{c}-0.00230 \\
(0.006)\end{array}$ & $\begin{array}{c}-0.00279 \\
(0.007)\end{array}$ \\
\hline CPL_HFCF4 & $\begin{array}{c}-0.0390 \\
(0.027)\end{array}$ & $\begin{array}{c}-0.0448 \\
(0.030)\end{array}$ & $\begin{array}{l}-0.0463 \\
(0.041)\end{array}$ & $\begin{array}{l}-0.0259 \\
(0.034)\end{array}$ & $\begin{array}{c}-0.0486 * * * \\
(0.018)\end{array}$ & $\begin{array}{c}-0.0478 * * \\
(0.024)\end{array}$ \\
\hline Adjusted $R^{2}$ & $\cdot$ & $\cdot$ & . & $\cdot$ & . & . \\
\hline \multicolumn{7}{|l|}{ EA13 } \\
\hline $\mathrm{OG}$ & $\begin{array}{c}0.156 \\
(0.816)\end{array}$ & $\begin{array}{l}0.0827 \\
(0.254)\end{array}$ & $\begin{array}{c}0.117 \\
(0.359)\end{array}$ & $\begin{array}{c}0.173 \\
(0.906)\end{array}$ & $\begin{array}{c}0.118 \\
(0.621)\end{array}$ & $\begin{array}{c}0.127 \\
(0.655)\end{array}$ \\
\hline DNEER_4 & $\begin{array}{c}-0.00419 \\
(0.020)\end{array}$ & $\begin{array}{c}-0.00391 \\
(0.009)\end{array}$ & $\begin{array}{c}-0.00532 \\
(0.012)\end{array}$ & $\begin{array}{c}-0.00461 \\
(0.022)\end{array}$ & $\begin{array}{c}-0.00387 \\
(0.015)\end{array}$ & $\begin{array}{c}-0.00324 \\
(0.016)\end{array}$ \\
\hline CPL_HFCF4 & $\begin{array}{c}-0.0763 \\
(0.120)\end{array}$ & $\begin{array}{l}-0.0536 \\
(0.034)\end{array}$ & $\begin{array}{c}-0.0574 \\
(0.048)\end{array}$ & $\begin{array}{l}-0.0810 \\
(0.134)\end{array}$ & $\begin{array}{l}-0.0734 \\
(0.091)\end{array}$ & $\begin{array}{l}-0.0433 \\
(0.095)\end{array}$ \\
\hline Adjusted $R^{2}$ & . & . & . & . & & . \\
\hline \multicolumn{7}{|l|}{ EA15 } \\
\hline $\mathrm{OG}$ & $\begin{array}{c}0.271 \\
(1.454)\end{array}$ & $\begin{array}{c}0.280 \\
(1.483)\end{array}$ & $\begin{array}{c}0.317 \\
(1.677)\end{array}$ & $\begin{array}{c}0.263 \\
(1.246)\end{array}$ & $\begin{array}{c}0.264 \\
(1.414)\end{array}$ & $\begin{array}{c}0.221 \\
(1.173)\end{array}$ \\
\hline DNEER_4 & $\begin{array}{c}0.00617 \\
(0.036)\end{array}$ & $\begin{array}{c}0.00330 \\
(0.028)\end{array}$ & $\begin{array}{c}0.00375 \\
(0.032)\end{array}$ & $\begin{array}{c}0.00603 \\
(0.030)\end{array}$ & $\begin{array}{c}0.00579 \\
(0.035)\end{array}$ & $\begin{array}{c}0.00608 \\
(0.029)\end{array}$ \\
\hline CPL_HFCF4 & $\begin{array}{c}-0.0646 \\
(0.244)\end{array}$ & $\begin{array}{c}-0.0643 \\
(0.206)\end{array}$ & $\begin{array}{c}-0.0668 \\
(0.234)\end{array}$ & $\begin{array}{r}-0.0723 \\
(0.211)\end{array}$ & $\begin{array}{r}-0.0607 \\
(0.237)\end{array}$ & $\begin{array}{c}-0.0403 \\
(0.196)\end{array}$ \\
\hline Adjusted $R^{2}$ & . & . & . & $\cdot$ & . & $\cdot$ \\
\hline $\begin{array}{l}\text { Notes: Models (1 } \\
\text { Foods, Labour Co } \\
\text { GGD and CPL_H } \\
\text { lagged Comparat } \\
\text { lagged values. ** }\end{array}$ & (4), (5) and & aclude as depe & variable the & th rate in $H I C$ & $\overline{C P}$ less Ener & $\begin{array}{l}\text { d Unprocesse } \\
D G, D N E E R \_4 \\
\text { eral Deficit an } \\
\text { nented by thei }\end{array}$ \\
\hline
\end{tabular}




\subsection{GMM estimates - robustness check}

Table 10A: Inflation differentials in the Euro area - robustness check I. GMM estimates for Eurostat yearly data 1999-2007

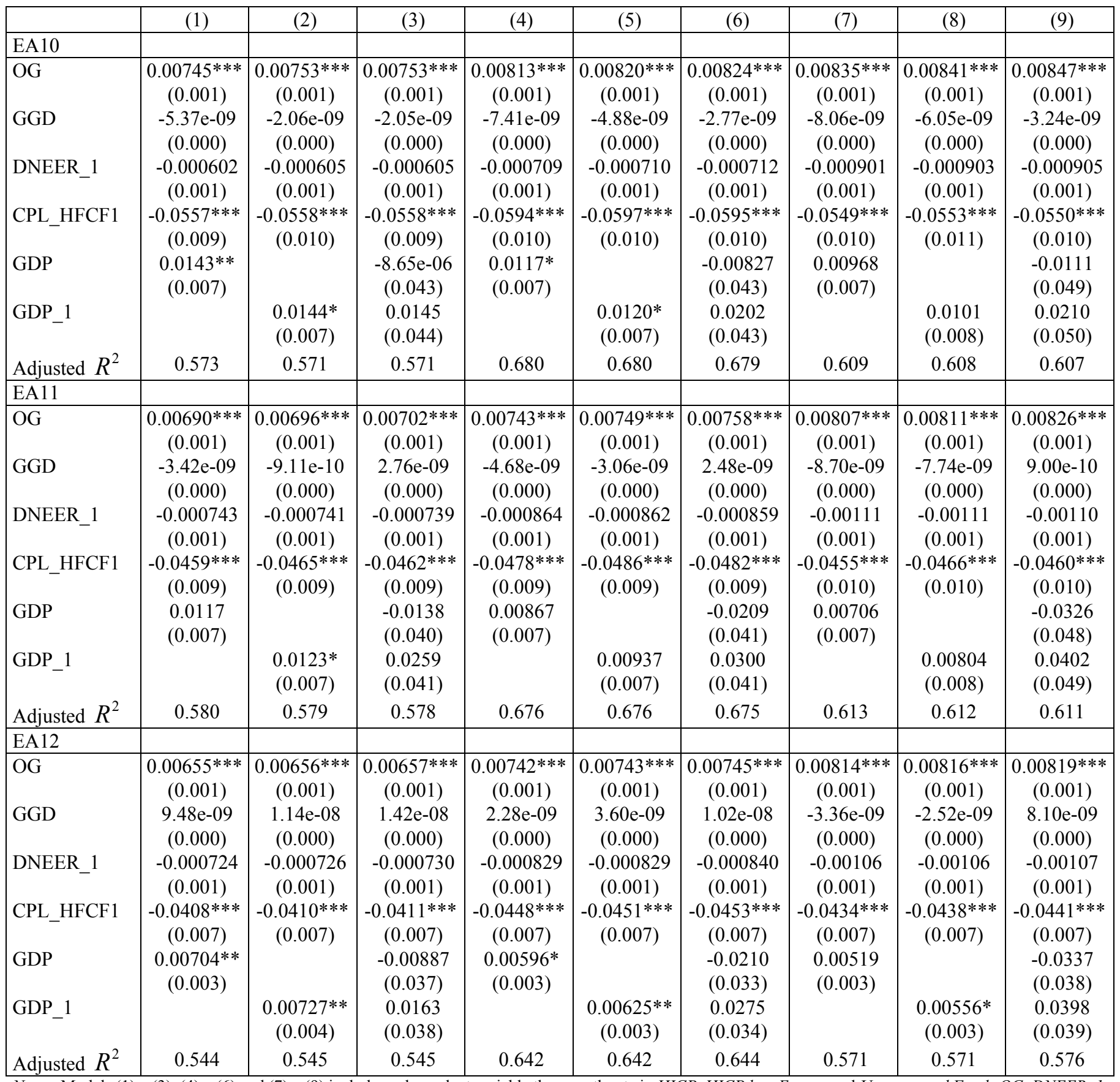

Notes: Models (1) - (3), (4) - (6) and (7) - (9) include as dependent variable the growth rate in HICP, HICP less Energy and Unprocessed Foods OG, DNEER_1, GGD, CPL HFCE1, GDP and GDP 1 account for Output Gap, lagged differenced Nominal Effective Exchange Rate, Government General Deficit and lagged Comparative Price Level (Household Final Consumption Expenditure), GDP per capita and lagged GDP per capita respectively. Output Gap (OG) is instrumented by their lagged values. $* * *, * *$ and $*$ denote significance at the 1,5 and $10 \%$ levels respectively. Robust standard errors in parentheses. All computations done using commands for StataSE 10.0. 


\section{Table 11A: Inflation differentials in the Euro area - robustness check II. GMM estimates for Eurostat yearly data 1999-2007}

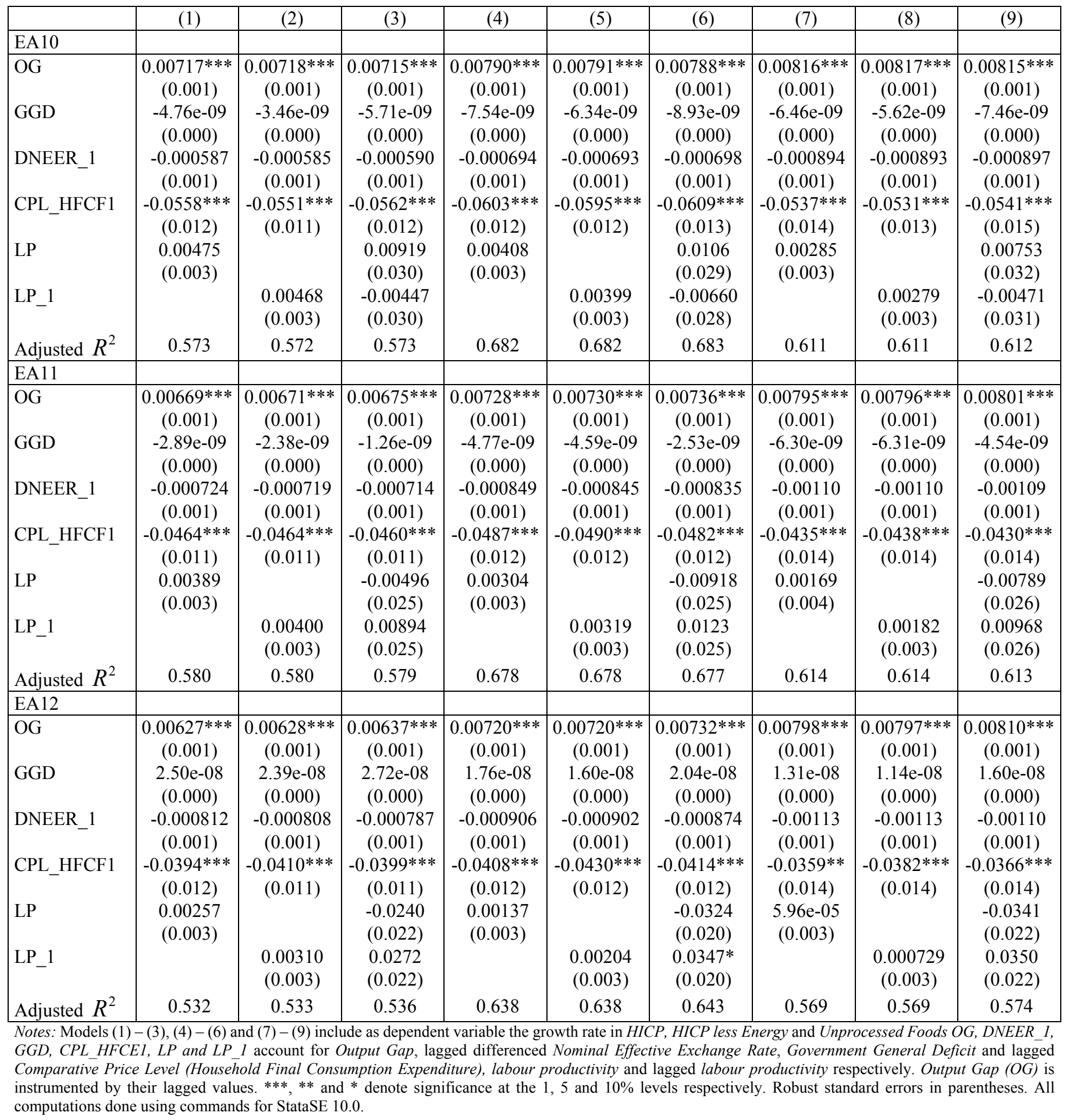


Table 12A: Stepwise regression, GMM, Eurostat yearly data, total HICP, 1999-2008

\begin{tabular}{|c|c|c|c|c|c|c|c|c|c|c|c|c|c|}
\hline & EA12 & $\mathrm{AT}$ & $\mathrm{BE}$ & $\mathrm{DE}$ & ES & FI & FR & GR & IE & \begin{tabular}{|c|} 
IT \\
\end{tabular} & LU & NL & PT \\
\hline $\mathrm{OG}$ & $\begin{array}{c}0.00610^{* * *} \\
(0.002)\end{array}$ & $\begin{array}{c}0.00578 * * * \\
(0.002)\end{array}$ & $\begin{array}{c}0.00593 * * * \\
(0.002)\end{array}$ & $\begin{array}{c}0.00632 * * * \\
(0.002)\end{array}$ & $\begin{array}{c}0.00582 * * * \\
(0.002)\end{array}$ & $\begin{array}{c}0.00559 * * * \\
(0.002)\end{array}$ & $\begin{array}{c}0.00640 * * * \\
(0.002)\end{array}$ & $\begin{array}{c}0.00608 * * * \\
(0.002)\end{array}$ & $\begin{array}{c}0.00630 * * * \\
(0.002)\end{array}$ & $\begin{array}{c}0.00564 * * * \\
(0.002)\end{array}$ & $\begin{array}{c}0.00637 * * * \\
(0.002)\end{array}$ & $\begin{array}{c}0.00619 * * * \\
(0.002)\end{array}$ & $\begin{array}{c}0.00625 * * * \\
(0.002)\end{array}$ \\
\hline GGD & $\begin{array}{c}1.02 \mathrm{e}-07 * \\
(0.000)\end{array}$ & $\begin{array}{c}1.11 \mathrm{e}-07 * \\
(0.000)\end{array}$ & $\begin{array}{c}1.20 \mathrm{e}-07 * * \\
(0.000)\end{array}$ & $\begin{array}{c}1.55 \mathrm{e}-07^{* *} \\
(0.000)\end{array}$ & $\begin{array}{c}8.99 \mathrm{e}-08 * \\
(0.000)\end{array}$ & $\begin{array}{c}1.39 \mathrm{e}-07^{* *} \\
(0.000)\end{array}$ & $\begin{array}{c}6.18 \mathrm{e}-08 \\
(0.000)\end{array}$ & $\begin{array}{c}1.03 \mathrm{e}-07 * \\
(0.000)\end{array}$ & $\begin{array}{c}7.13 \mathrm{e}-08 \\
(0.000)\end{array}$ & $\begin{array}{c}1.24 \mathrm{e}-07 * \\
(0.000)\end{array}$ & $\begin{array}{c}7.16 \mathrm{e}-08 \\
(0.000)\end{array}$ & $\begin{array}{c}9.78 \mathrm{e}-08^{*} \\
(0.000)\end{array}$ & $\begin{array}{c}9.52 \mathrm{e}-08^{*} \\
(0.000)\end{array}$ \\
\hline DNEER_1 & $\begin{array}{c}-0.000851 \\
(0.001)\end{array}$ & $\begin{array}{c}-0.00101 \\
(0.001)\end{array}$ & $\begin{array}{c}-0.00101 \\
(0.001)\end{array}$ & $\begin{array}{c}-0.000644 \\
(0.001)\end{array}$ & $\begin{array}{c}-0.000579 \\
(0.001)\end{array}$ & $\begin{array}{c}-0.000118 \\
(0.001)\end{array}$ & $\begin{array}{c}-0.00144 \\
(0.001)\end{array}$ & $\begin{array}{c}-0.000783 \\
(0.001)\end{array}$ & $\begin{array}{c}-0.00113 \\
(0.001)\end{array}$ & $\begin{array}{c}-0.00106 \\
(0.001)\end{array}$ & $\begin{array}{c}-0.000635 \\
(0.001)\end{array}$ & $\begin{array}{c}-0.000922 \\
(0.001)\end{array}$ & $\begin{array}{c}-0.000972 \\
(0.001)\end{array}$ \\
\hline CPL_HFCF1 & $\begin{array}{c}-0.00923 \\
(0.017)\end{array}$ & $\begin{array}{c}-0.00891 \\
(0.017)\end{array}$ & $\begin{array}{c}-0.00858 \\
(0.017)\end{array}$ & $\begin{array}{l}-0.0104 \\
(0.017)\end{array}$ & $\begin{array}{c}-0.00481 \\
(0.020)\end{array}$ & $\begin{array}{c}0.00542 \\
(0.021)\end{array}$ & $\begin{array}{l}-0.0142 \\
(0.015)\end{array}$ & $\begin{array}{c}-0.00946 \\
(0.022)\end{array}$ & $\begin{array}{c}-0.0284 * * * \\
(0.010)\end{array}$ & $\begin{array}{r}-0.0103 \\
(0.017)\end{array}$ & $\begin{array}{l}-0.0109 \\
(0.018)\end{array}$ & $\begin{array}{c}-0.00802 \\
(0.017)\end{array}$ & $\begin{array}{c}0.000153 \\
(0.022)\end{array}$ \\
\hline Adjusted $R^{2}$ & 0.934 & 0.934 & 0.933 & 0.944 & 0.928 & 0.933 & 0.939 & 0.933 & 0.953 & 0.927 & 0.927 & 0.929 & 0.927 \\
\hline
\end{tabular}

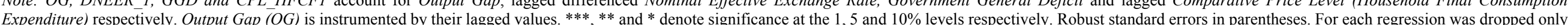
one country. Robust standard errors in parentheses. All computations done using commands for StataSE 10.0. 


\section{Dispersion in HICP I - five main sectors}

Figure 1A: Dispersion in HICP: services vs. HICP (left) and industrial good vs. HICP (right), y-on-y growth rates, the EA12 group of countries, 1999-2008
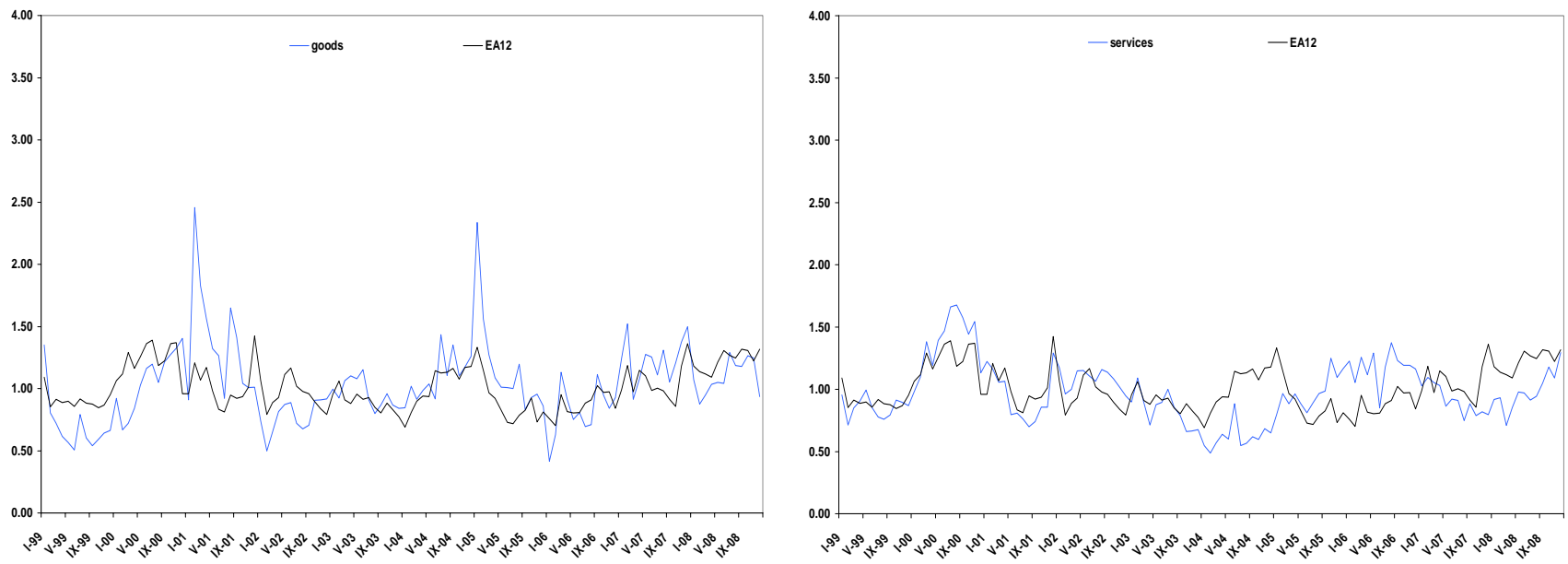

Note: services - the subindex Services (overall index excl. goods), industrial goods - the subindex Non-energy industrial goods, EA12 - the overall HICP index for the Euro area (EA12).

Source: BLS (2009), own calculations.

Figure 2A: Dispersion in HICP: energy vs. HICP (left) and processed and unprocessed food vs. HICP (right), y-on-y growth rates, the EA12 group of countries, 1999-2008
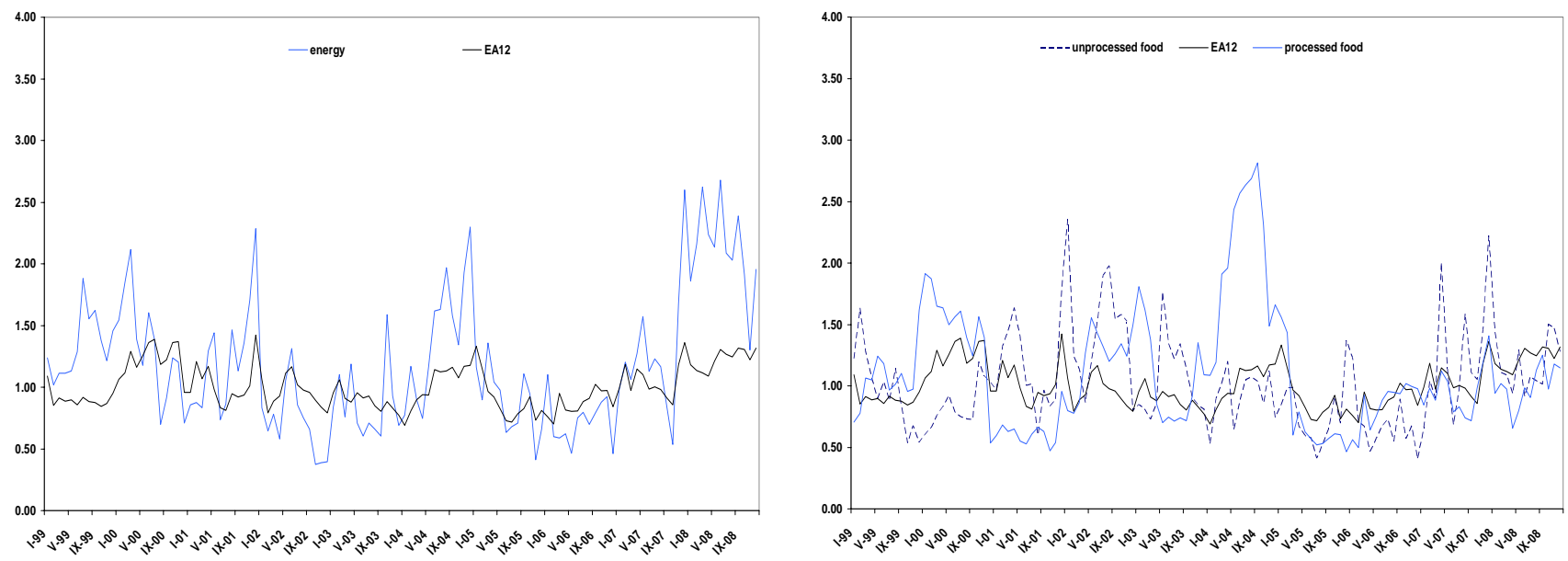

Note: energy - the subindex Energy, processed and unprocessed food - the subindices Processed food and Unprocessed food, EA12 - the overall HICP index for the Euro area (EA12).

Source: BLS (2009), own calculations. 
Figure 3A: Relative contributions of the main sectors to the overall HICP dispersion, the EA12 group of countries, 1999-2008

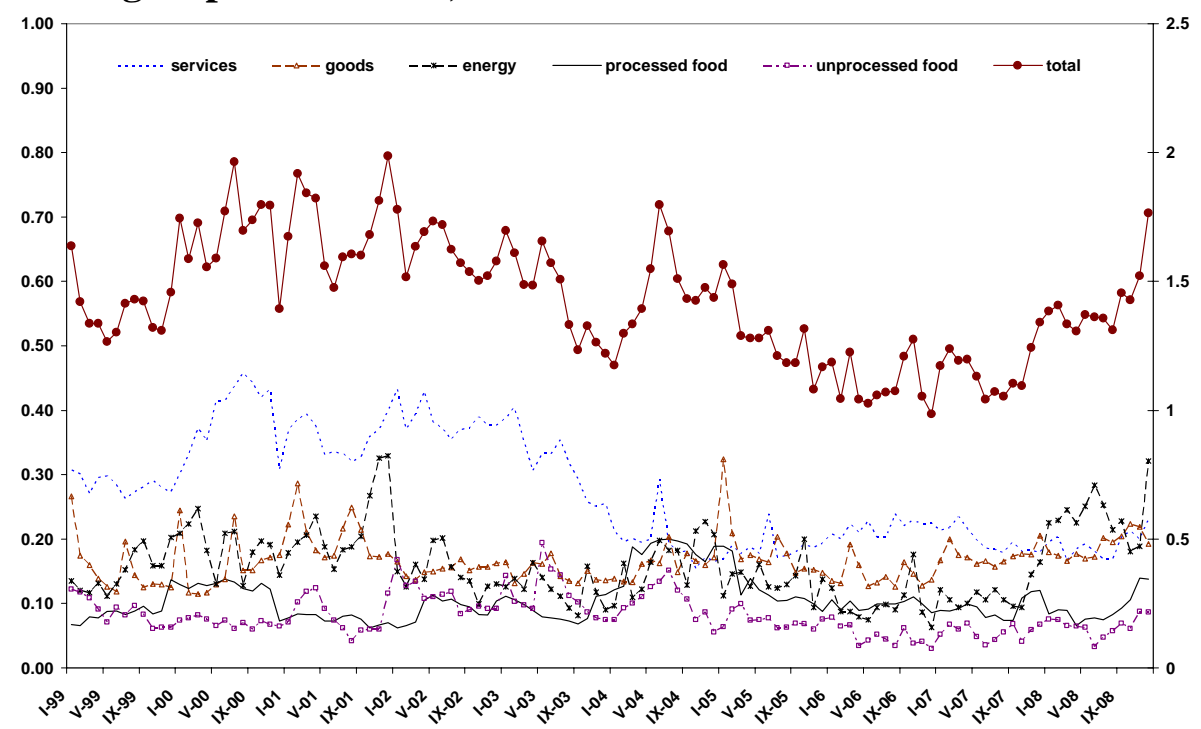

Note: services - the subindex Services (overall index excl. goods), industrial goods - the subindex Non-energy industrial goods, energy - the subindex Energy, processed and unprocessed food - the subindices Processed food and Unprocessed food, total - the overall HICP index. Source: Eurostat (2009), own calculation.

Figure 4A: Dispersion in HICP: relative contributions of individual sectors, the EA12 group of countries, 1999-2008
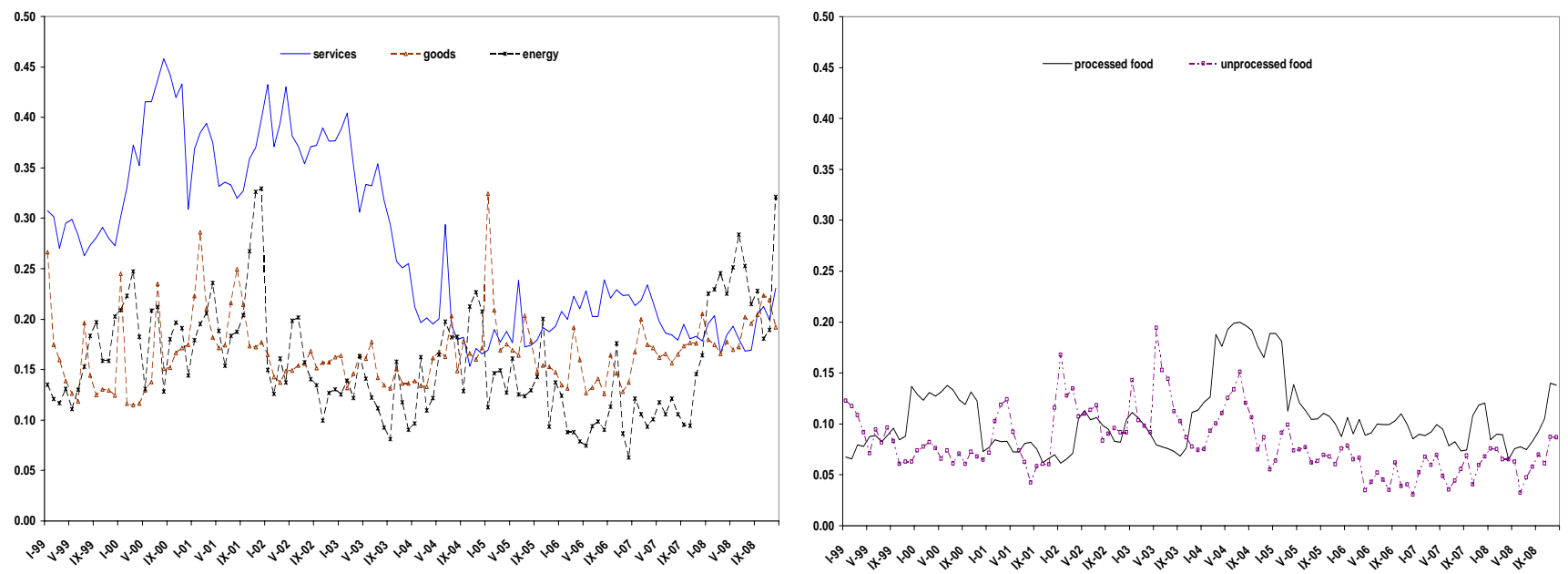

Note: services - the subindex Services (overall index excl. goods), industrial goods - the subindex Non-energy industrial goods, energy - the subindex Energy, processed and unprocessed food - the subindices Processed food and Unprocessed food, total - the overall HICP index. Source: BLS (2009), own calculations. 


\section{Dispersion in HICP I - twelve main sectors}

Figure 5A: Dispersion in HICP: food vs. HICP (left) and beverages vs. HICP (right), y-on-y growth rates, the $\mathrm{EA12}$, 1999-2008
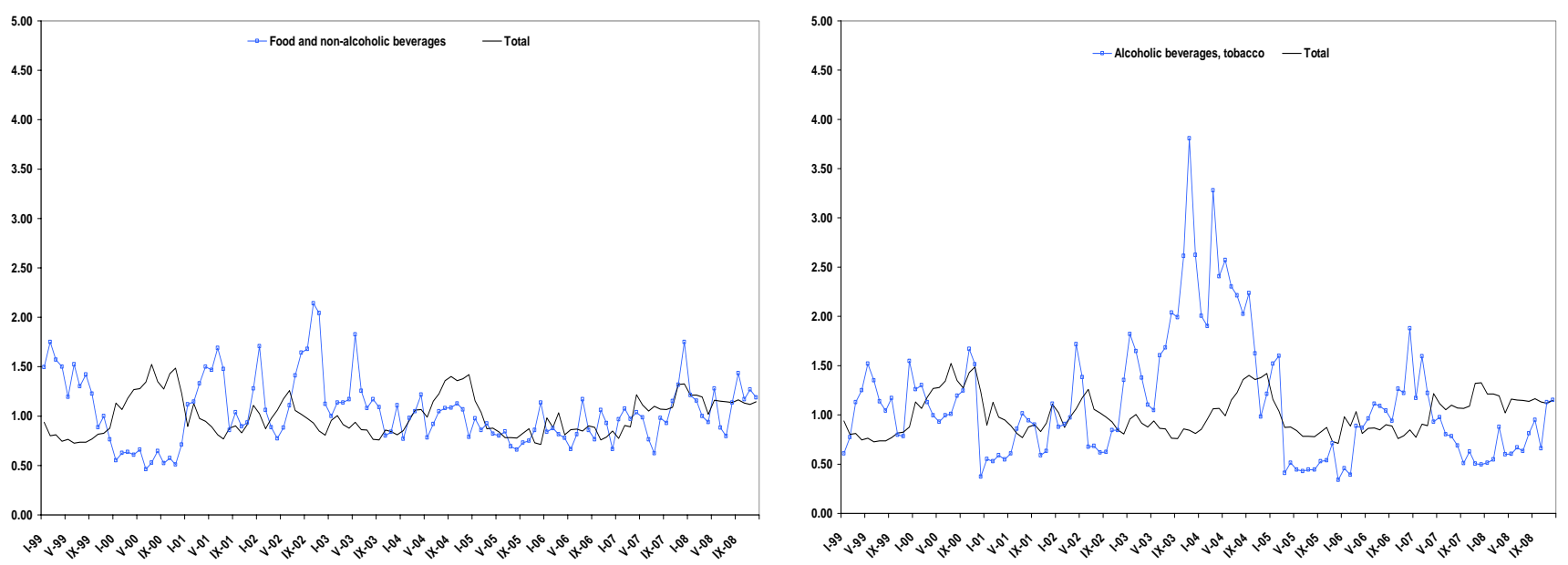

Note: Food and alcoholic beverages - the subindex Food and non-alcoholic beverages, Alcoholic beverages, tobacco - the subindex Alcoholic beverages, tobacco and narcotics, Total - the overall HICP index for the Euro area (EA12). Source: BLS (2009), own calculations.

Figure 6A: Dispersion in HICP: clothing and footwear vs. HICP (left) and housing, water, energy vs. HICP (right), y-on-y growth rates, the EA12, 1999-2008
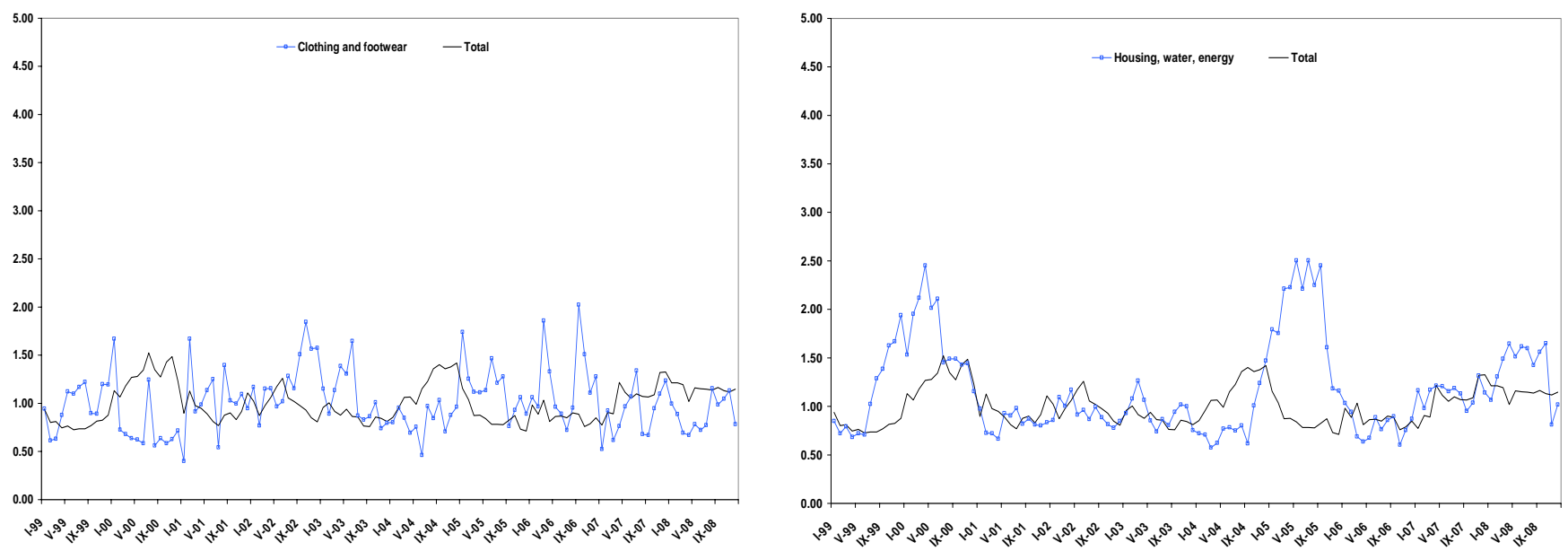

Note: clothing and footwear - the subindex Clothing and footwear, housing, water, energy - Housing, water, electricity, gas and other fuels, Total the overall HICP index for the Euro area (EA12).

Source: BLS (2009), own calculations. 
Figure 7A: Dispersion in HICP: Furnishings, household equipment and maintenance vs. HICP (left) and Housing, water, energy vs. HICP (right), y-on-y growth rates, the EA12, 1999-2008
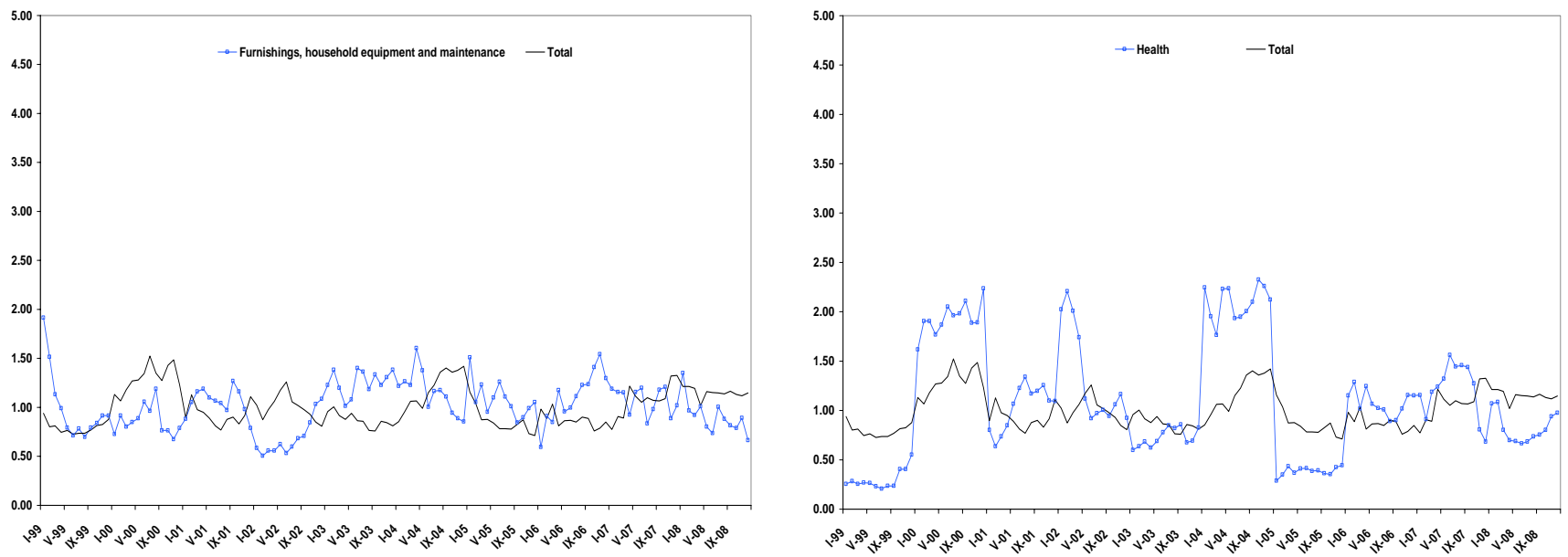

Note: Furnishings, household equipment and maintenance - the subindex Furnishings, household equipment and routine maintenance of the house, health - the subindex Health, Total - the overall HICP index for the Euro area (EA12).

Source: BLS (2009), own calculations.

Figure 8A: Dispersion in HICP: transport vs. HICP (left) and communication vs. HICP (right), y-on-y growth rates, the EA12, 1999-2008
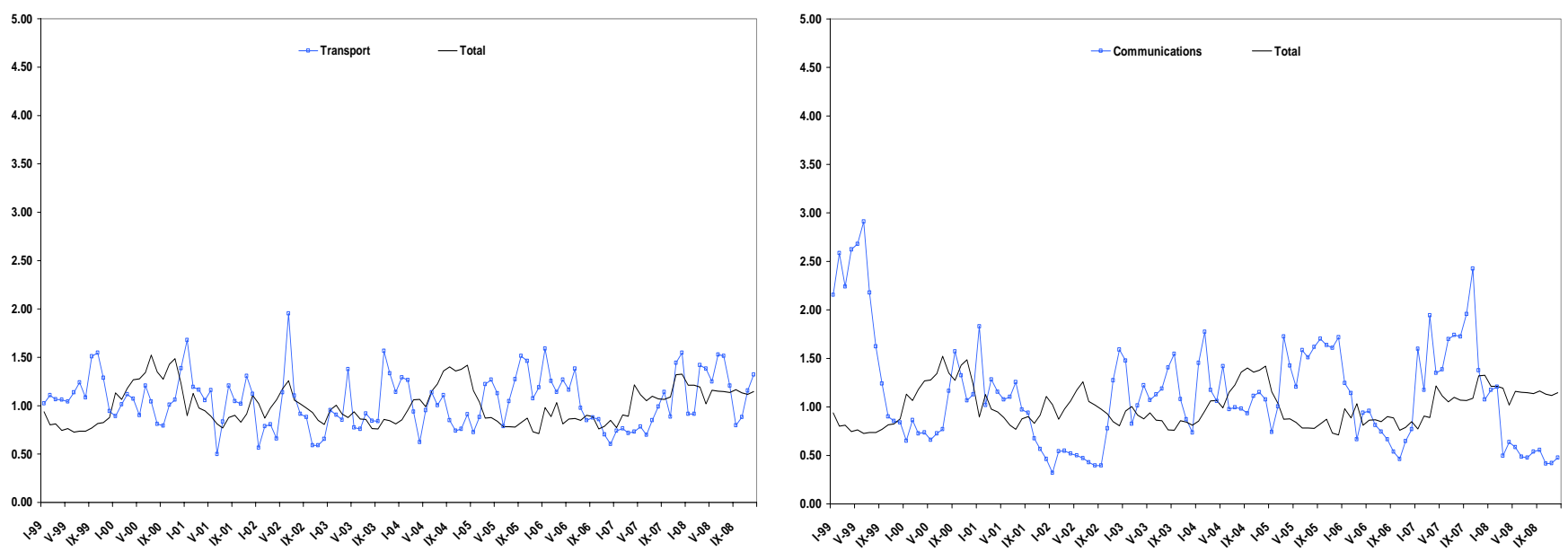

Note: transport - the subindex Transport, communications - the subindex Communications, Total - the overall HICP index for the Euro area (EA12).

Source: BLS (2009), own calculations. 
Figure 9A: Dispersion in HICP: recreation and culture vs. HICP (left) and education vs. HICP (right), y-on-y growth rates, the EA12, 1999-2008
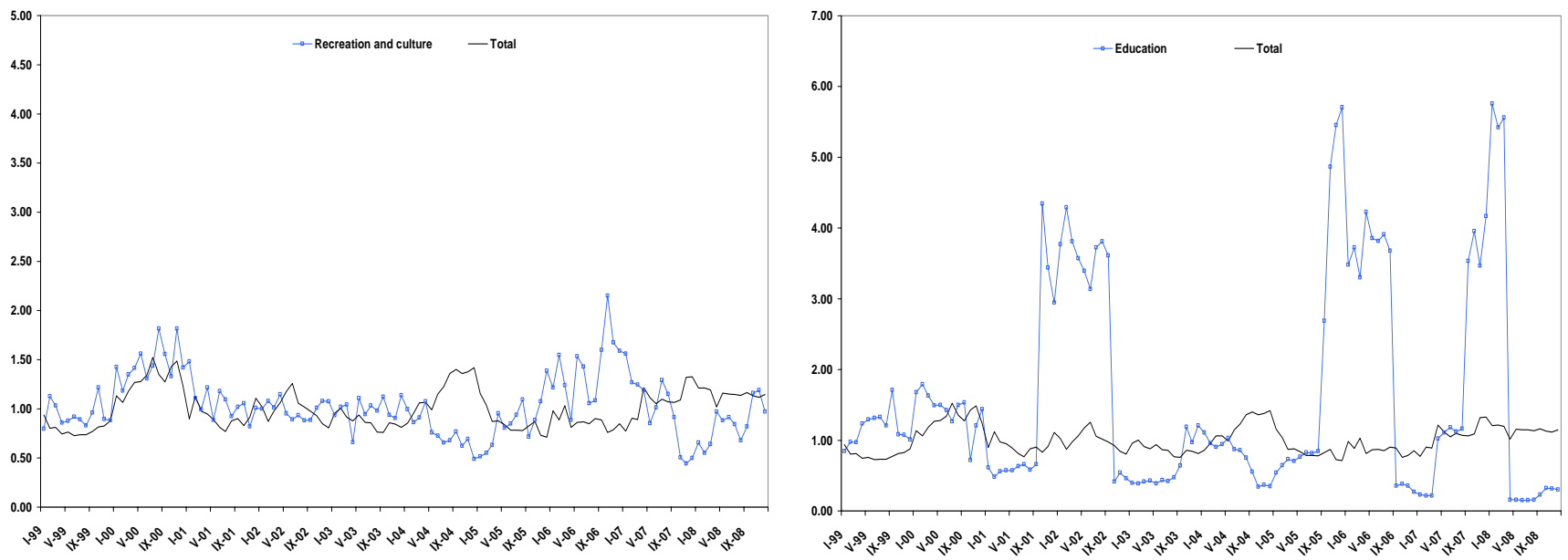

Note: recreation and culture - the subindex Recreation and culture, education - the subindex Education, Total - the overall HICP index for the Euro area (EA12).

Source: BLS (2009), own calculations.

Figure 10A: Dispersion in HICP: restaurants and hotels vs. HICP (left) and misc vs. HICP (right), y-on-y growth rates, the EA12, 1999-2008
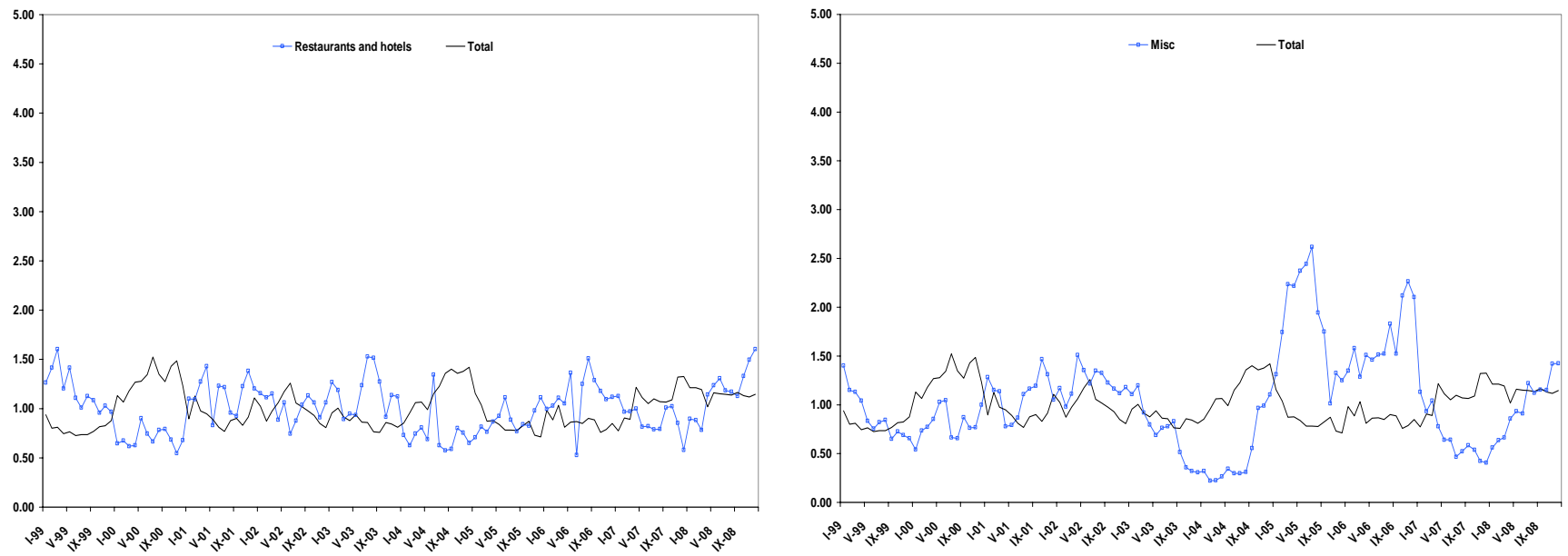

Note: restaurants and hotels - the subindex Restaurants and hotels, misc - the subindex Miscellaneous goods and services, Total - the overall HICP index for the Euro area (EA12).

Source: BLS (2009), own calculations. 


\section{References}

Altissimo, F., Benigno, P. and Rodriguez, P. D. (2005). Long run determinants of inflation differentials in a monetary union. Cambridge, MA : National Bureau of Economic Research, NBER Working Paper Series No. 11473, July 2005.

Angeloni, I. and Ehrmann, M. (2007). Euro area inflation differentials. The B.E. Journal of Macroeconomics, 2007, vol. 7 (1), 34 p.

Auerbach, A. J. (2008). Federal Budget Rules: The US Experience. Cambridge, MA : National Bureau of Economic Research, NBER Working Paper Series No. 14288, August 2008.

Balassa, B. (1964). The purchasing power parity doctrine: a reappraisal. The Journal of Political Economy, 1964, vol. 72, (6), pp. 584-596.

Baltagi, B. H. (2008). Econometrics analysis of panel data (4th ed.). Chichester : Wiley, 2008.

Bentivogli, Ch., Pagano, P. (1999). Regional Disparities and Labour Mobility: the Euro-11 versus the USA. Labour, 1999, vol. 13, issue 3, pp. 737-760.

Beck, G. W., Weber, A. A. (2005). Inflation rate Dispesion and Convergence In Monetary and Economic Unions: Lessons for the ECB. Frankfurt am Main: Centre for Financial Studies, CFS Working Paper No. 31.

Beck, G. W., Hubrich, K., Marcellino, M. (2006). Regional Inflation dynamics within and across Euro Area Countries and a Comparison with the US. Frankfurt : ECB, ECB Working Paper No. 681, October 2006.

Beetsma, R, Debrun, X., Klaassen, F. (2001). Is Fiscal Policy Coordination in EMU Desirable? London : CEPR, CEPR Discussion Ppaer No. 3035, October 2001.

Benigno, P. (2004). Optimal monetary policy in a currency area. Journal of International Economics, (63): 293-320.

Bick, A. and Nautz, D. (2008). Inflation Thresholds and Relative Price Variability: Evidence from U.S. Cities. International Journal of Central Banking, September 2008, 4 (3): 61-76.

BLS (2009). Database Prices. Washington, D.C. : Bureau of Labour Statistics, 2009. URL: http://www.bls.gov.

Busetti, F., Forni, L., Harvey, A. and Venditti, F. (2006). Inflation Convergence and Divergence within the European Monetary Union. Frankfurt : ECB, ECB Working Paper Series No. 574, January 2006.

Cecchetti, S., Mark, N. C. and Sonora, R. (2002). Price level Convergence among United States 
Cities: Lessons for the European Central Bank. International Economic Review, 43, 2002, 4, pp. 1081-1099.

Daianu, D., Lungu, L. (2009). The Monetary Union: The Decade Ahead. The Case of Non-Member States. Michigan : The William Davidson Institute, The WDI Working Paper No. 947, January 2009.

Decresssin, J., Fatás, A. (1995). Regional labour market dynamics in Europe. European Economic Review, December 1995, vol. 39 (9), pp. 1627-1655.

De Grauwe, P. (2007). Economics of monetary union (7th ed.). Oxford : Oxford University Press, 2007.

De Grauwe, P., Vanhaverbeke, W. (2001). Is Europe an optimum currency area?: evidence from regional data. In: De Grauwe, P. (ed.) The Political Economy of Monetary Union. Cheltenham : Edward Elgar Publishing, 2001, pp. 168-186.

Dullien, S., Schwarzer, D. (2009). Bringing Macroeconomics into the EU Budget Debate: Why and How? Journal of Common Market Studies, 2009, vol. 47, No. 1, pp. 153-174.

ECB (2003). Euro area inflation differentials. Frankfurt : European Central Bank, September 2003.

ECB (2009). Data. Prices. Statistical database. Frankfurt : European Central Bank. URL: http://sdw.ecb.europa.eu/reports.do?node=100000181.

EC (2006). Public Finances in EMU - 2006. Luxembourg : European Commission, DG ECFIN, European Economy No. $3 . \quad$ URL: http://ec.europa.eu/economy_finance/publications/publication423_en.pdf.

EC (2006a). Employment in Europe 2006. Luxembourg : European Commission, DG ESA, October 2006a, 291 pp. URL: http://ec.europa.eu/employment_social/employment_analysis/employ_2006_en.htm.

EC (2008). Employment in Europe 2008. Luxembourg : European Commission, DG ESA, October 2008, 283 pp. URL: http://ec.europa.eu/social/main.jsp?catId=119\&langId=en.

Égert, B., Ritzberger-Grunwald, D. and Silgoner, M. (2004). Inflation Differentials in Europe: Past Experience and Future Prospects. Monetary Policy \& the Economy, Q1, May 2004, pp. 47-72.

Égert, B. (2007). Real convergence, price level convergence and inflation differentials in Europe. Michigan : The William Davidson Institute at the University of Michigan, WDI Working Paper No. 895, October 2007.

Eurostat (2009). Database Prices. Luxembourg : Eurostat, 2009. URL: http://epp.eurostat.ec.europa.eu/.

Fatas, A. and Mihov, I. (2009). The Euro and Fiscal Policy. Cambridge, MA : National Bureau of 
Economic Research, NBER Working Paper Series No. 14722, February 2009.

Feldstein, M. S. (1997). The political economy of the european economic and monetary union: Political sources of an economic liability. The Journal of Economic Perspectives, Fall 1997, vol. 11 (4), pp. 23-42.

Fendel, R. and Frenkel, M. (2008). Inflation differentials in the Euro area: did the ECB care? Applied Economics, forth.

Fernández, R. (1981). A methodological note on the estimation of time series. The Review of Economics and Statistics, August 1981, vol. 63(3), pp. 471-476.

Friedman, M. (1953). The Case for Flexible Exchange Rates. In: Essay ins Positive Economics, Chicago : University of Chicago Press, 1953, pp. 157-203.

Greene, W. J. (2008). Econometrics Analysis (6th ed.). Upper Saddle River, NJ : Pearson Prentice Hall, 2008.

Gregoriou, A., Kontonikas, A. and Montagnoli, A. (2006). Euro Area Inflation Differentials: Unit Roots, Structural Breaks and Non-Linear Adjustment. University of Glasgow, Department of Economics, Working Paper No. 13, June 2007.

HMS 2003. The United States as a monetary union. EMU study. Norwich : HMSO, 2003.

Hofmann, B. and Remsperger, H. (2005). Inflation differentials among the euro area countries: Potential causes and consequences. Journal of Asian Economics, 2005, vol. 16 (3), pp. 403-419.

Honohan, P. and Lane, P. (2003). Divergent inflation rates in emu. Economic Policy, 2003, vol. 18 (37), pp.358-394.

Honohan, P. and Lane, P. (2004). Exchange rates and inflation under emu: an update. Dublin : Trinity College Dublin \& CEPR, IIIS Discussion Paper, No. 31, July 2004.

Horváth, R. and Koprnická, K. (2008). Inflation differentials in eu new member states. Prague : IES, Charles University, IES Working Paper No. 24.

IMAD (2007). Euro changeover effect on inflation in Slovenia. Ljubljana : Statistical Office of the Republic of Slovenia, March 2, 2007. URL: http://www.stat.si/eng/evro.asp.

IMF (2004). World Economic Outlook. The Global Demographic Transition. Washington, D.C. : International Monetary Fund, September 2004.

IMF (2008). World Economic Outlook. Financial Stress, Downturns, and Recoveries. Washington, D.C. : International Monetary Fund, October 2008.

Issing, O. (2008). The Birth of the Euro. Cambridge : Cambridge University Press, 2008. 
Lewis, J. (2007). Hitting and Hoping? Meeting the Exchange Rate and Inflation Criteria During a Period of Nominal Convergence. Amsterdam : De Nederlandsche Bank, DNB Working Paper No. 130.

Mátyás, L. (eds.) (2008). The econometrics of panel data: fundamentals and recent developments in theory and practice (3rd ed.) Berlin : Springer, 2008.

Mundell, (1961). A Theory of Optimum Currency Areas. American Economic Review, September 1961, vol. 51 (4), pp. 657-665.

Obstfeld, M. (1997). Europe's gamble. Brookings Papers on Economic Activity, vol. 28 (1997-2), pp. 241-317.

Obstfeld, M. (1997). EMU Ready, or Not? Cambridge, MA: National Bureau of Economic Research, NBER Working Paper No. 6682, August 1998.

Perotti, R. (2004). Estimating the effects of fiscal policy in OECD countries. Milano : IGIER Università Bocconi, Working Paper no. 276, December 2004.

Samuelson, P. (1964). Theoretical notes on trade problems. Review of Economics and Statistics, February 1964, vol. 46 (2), pp. 145-154.

Sinn, H.-W., Reutter, M. (2001). The minimum inflation rate for euroland. Cambridge, MA : National Bureau of Economic Research, NBER Working Paper No. 8085, January 2001.

Weber, A. A., Beck, G. W. (2005). Price Stability, Inflation Convergence and Diversity in EMU: Does One Size Fit All? Frankfurt : Centre for Financial Studies, CFS Working Paper No. 30.

Weyerstrass, K. (2008). Economic policies on Slovenia's road to the euro area. Economic Systems, March 2008, vol. 32 (1), pp. 92-102.

Žd'árek, V. (2008). Some Thoughts on Nominal Convergence, Its Drivers and Determinants for the new EU Member States Preparing the Euro Adoption. Prague Economic Papers, 2008, vol. 15 (4), pp. 291-318. 


\section{DAVIDSON INSTITUTE WORKING PAPER SERIES - Most Recent Papers}

The entire Working Paper Series may be downloaded free of charge at: www.wdi.umich.edu

CURRENT AS OF 5/1/09

\begin{tabular}{|c|c|c|}
\hline Publication & Authors & Date \\
\hline $\begin{array}{l}\text { No. 958: Inflation differentials in the Euro area and their determinants } \\
\text { - an empirical view }\end{array}$ & $\begin{array}{c}\text { Juan Ignacio Aldasoro \& Václav } \\
\text { Žd'árek }\end{array}$ & April 2009 \\
\hline No. 957: Infrastructure and growth: Empirical evidence & $\begin{array}{c}\text { Balazs Egert, Tomasz } \\
\text { Kozluk and Douglas Sutherland }\end{array}$ & April 2009 \\
\hline $\begin{array}{l}\text { No. 956: Infrastructure investment in network industries: The role of } \\
\text { incentive regulation and regulatory independence }\end{array}$ & Balazs Egert & April 2009 \\
\hline $\begin{array}{l}\text { No. 955: The impact of monetary and commodity fundamentals, macro } \\
\text { news and central bank communication on the exchange rate: } \\
\text { Evidence from South Africa }\end{array}$ & Balazs Egert & April 2009 \\
\hline $\begin{array}{l}\text { No. 954: "Family" ownership, tunneling and earnings management: } \\
\text { A review of the literature }\end{array}$ & $\begin{array}{l}\text { Sumon Bhaumik and Andros } \\
\text { Gregoriou }\end{array}$ & $\begin{array}{l}\text { March } \\
2009\end{array}$ \\
\hline $\begin{array}{l}\text { No. 953: Impact of Foreign Direct Investments on Industrial Productivity: } \\
\text { A Subnational Study of India }\end{array}$ & Krishna C. Vadlamannati & $\begin{array}{l}\text { March } \\
2009\end{array}$ \\
\hline $\begin{array}{l}\text { No. 952: Determinants of Exchange Rate Practices in the MENA } \\
\text { Countries: Some Further Empirical Results }\end{array}$ & Sfia, M. Daly and Mouley Sami & Jan 2009 \\
\hline No. 951: An Analytic Approach To Selecting A Nonprofit & $\begin{array}{l}\text { Andrés Ramírez and } \\
\text { Hakan Saraoglu }\end{array}$ & Jan 2009 \\
\hline $\begin{array}{l}\text { No. 950: Anthropometry of Love } \\
\text { Height and Gender Asymmetries in Interethnic Marriages }\end{array}$ & Michèle Belot and Jan Fidrmuc & Jan 2009 \\
\hline No. 949: Is THE COST OF LIVING IN RUSSIA REALLY THAT LOW? & Konstantin Gluschenko & Dec 2008 \\
\hline $\begin{array}{l}\text { No. 948: Banking Market Liberalization and Bank Performance: the Role } \\
\text { of Entry Modes }\end{array}$ & Ngoc-Anh Vo Thi & Jan 2009 \\
\hline $\begin{array}{l}\text { No. 947: The Monetary Union: The Decade Ahead. } \\
\text { The Case of Non-Member States }\end{array}$ & Daniel Daianu and Laurian Lungu & Jan 2009 \\
\hline No. 946: Currency Substitution: A Case Of Kazakhstan (2000:1-2007:12) & $\begin{array}{l}\text { Mesut Yilmaz, Yessengali } \\
\text { Oskenbayev \& Kanat Abdulla }\end{array}$ & Jan 2009 \\
\hline $\begin{array}{l}\text { No. 945: Determinants Of Pollution Abatement And Control Expenditure: } \\
\text { Evidence From Romania }\end{array}$ & $\begin{array}{l}\text { Guglielmo Caporale, Christophe } \\
\text { Rault, Robert Sova \& Anamaria } \\
\text { Sova }\end{array}$ & Jan 2009 \\
\hline $\begin{array}{l}\text { No. 944: Bootstrap panel Granger-causality between government } \\
\text { spending and revenue in the EU }\end{array}$ & $\begin{array}{l}\text { Antonio Afonso and Christophe } \\
\text { Rault }\end{array}$ & Jan 2009 \\
\hline No. 943: Regional Determinants of FDI Distribution in Poland & $\begin{array}{l}\text { Agnieszka Chidlow and Stephen } \\
\text { Young }\end{array}$ & Nov 2008 \\
\hline No. 942: Structural Reform and Firm Exports & $\begin{array}{l}\text { Alvaro Cuervo-Cazurra \& Luis } \\
\text { Alfonso Dau }\end{array}$ & Sept 2008 \\
\hline $\begin{array}{l}\text { No. 941: Exploring The Relationship Between Military Spending \& } \\
\text { Human Rights Performance In South Asia }\end{array}$ & $\begin{array}{l}\text { Krishna Chaitanya, Vadlamannati } \\
\text { and K K Shakya Lahiru Pathmalal }\end{array}$ & Oct 2008 \\
\hline $\begin{array}{l}\text { No. 940: Structural Reform And Firm Profitability In Developing } \\
\text { Countries }\end{array}$ & $\begin{array}{l}\text { Alvaro Cuervo-Cazurra \& Luis } \\
\text { Alfonso Dau }\end{array}$ & July 2008 \\
\hline $\begin{array}{l}\text { No. 939: Does Timing Of Elections Instigate Riots? } \\
\text { A Subnational Study Of } 16 \text { Indian States, } 1958 \text { - } 2004\end{array}$ & Krishna Chaitanya Vadlamannati & Oct 2008 \\
\hline $\begin{array}{l}\text { No. 938: Price Setting And Market Structure: An Empirical Analysis Of } \\
\text { Micro Data }\end{array}$ & Fabrizio Coricelli \& Roman Horvath & Sept 2008 \\
\hline $\begin{array}{l}\text { No. 937: Inflation Differentials in EU New Member States: An Empirical } \\
\text { Evidence }\end{array}$ & Roman Horvath \& Kamila Koprnicka & Oct 2008 \\
\hline $\begin{array}{l}\text { No. 936: Market Reforms and Growth in Post-socialist Economies: } \\
\text { Evidence from Panel Cointegration and Equilibrium Correction Model }\end{array}$ & Igor Pelipas and Alexander Chubrik & Sept 2008 \\
\hline $\begin{array}{l}\text { No. 935: Derivatives trading and the volume-volatility link in the Indian } \\
\text { Stock Market }\end{array}$ & $\begin{array}{l}\text { S. Bhaumiky, M. Karanasosy and } \\
\text { A. Kartsaklas }\end{array}$ & April 2008 \\
\hline
\end{tabular}

